Aus der Abteilung Neuropathologie

(Prof. Dr. med. W. Brück)

im Zentrum Pathologie und Rechtsmedizin

der Medizinischen Fakultät der Universität Göttingen

\title{
Stickoxidmetabolite als Ursache einer differentiellen Myelingenexpression in MS-Läsionen?
}

\section{INAUGURAL-DISSERTATION}

\author{
zur Erlangung des Doktorgrades \\ der Medizinischen Fakultät \\ der Georg-August-Universität zu Göttingen \\ vorgelegt von \\ Anna Katharina Beck \\ aus \\ Zeven
}

Göttingen 2010 
Dekan: Prof. Dr. med. C. Frömmel

I. Berichterstatter: Prof. Dr. med. Brück

II. Berichterstatter/in: Prof. Dr. med. Simons

Tag der mündlichen Prüfung: 03. Mai 2011 


\section{Inhaltsverzeichnis}

$\begin{array}{ll}\text { Abkürzungsverzeichnis } & \text { IV }\end{array}$

$\begin{array}{ll}1 \text { Einleitung } & 1\end{array}$

1.1 Multiple Sklerose (MS) $\ldots . \ldots \ldots \ldots \ldots \ldots \ldots \ldots \ldots \ldots \ldots \ldots \ldots \ldots \ldots \ldots \ldots \ldots . . \ldots \ldots$

1.2 Das Myelin......................................................... 3

1.3 Die Myelinproteine................................................ 4

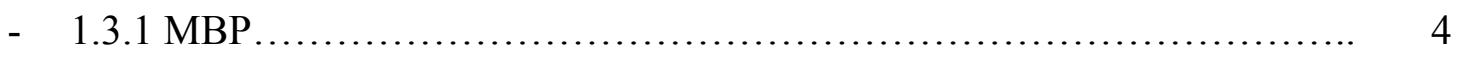

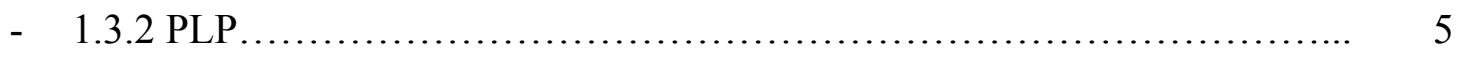

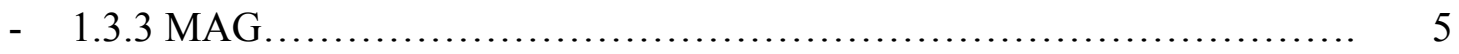

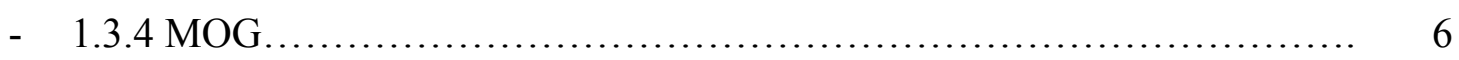

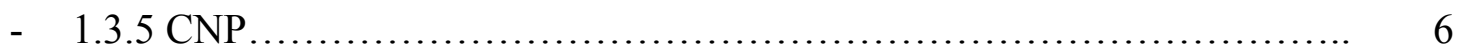

1.4 Zelllinien.................................................................. 7

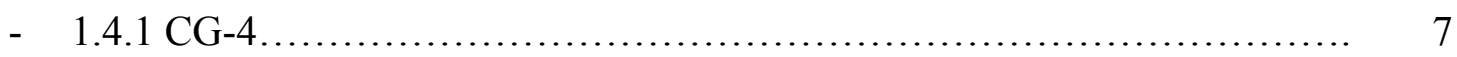

- 1.4 .2 OLN-93...................................................... 7

1.5 Zelltodinduktoren..................................................... 8

- $\quad$ 1.5.1 Stickoxid und Peroxynitrit........................................ 8

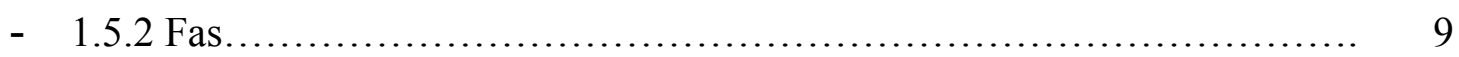

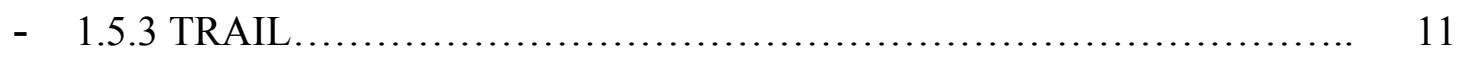

- 1.5 .4 Staurosporin................................................ 12

1.6 Fragestellung und Zielsetzung.................................. 13

$\begin{array}{lr}2 \text { Material und Methoden } & 14\end{array}$

2.1 Prinzipieller Ablauf der Versuchsreihen......................... 14

2.2 Zellkultur..................................................... 14

- 2.2.1 Passagieren von OLN-93 ..................................... 15

- $\quad 2.2 .2$ Passagieren von CG-4 ........................................... 15

- 2.2.3 Zählen und Aussäen der Zellen..................................... 16

- 2.2.4 Primärkultur.................................................... 16

- $\quad$ 2.2.5 Stimulation der Zellen.............................................. 17

- 2.2.6 Ernten der Zellen.................................................. 17 
2.4 TUNEL-Färbung............................................. 18

2.5 Nukleosomen-ELISA........................................ 19

2.6 RNA-Extraktion aus Zellpellets................................ 20

2.7 Synthese der cDNA........................................... 21

2.8 Polymerase-Ketten-Reaktion (PCR)........................... 22

2.9 Real Time PCR.................................................. 23

2.10 Agarose-Gel-Elektrophorese................................... 24

2.11 Medien und Puffer............................................... $\quad 25$

- 2.11.1 Zellkulturmedien........................................... 25

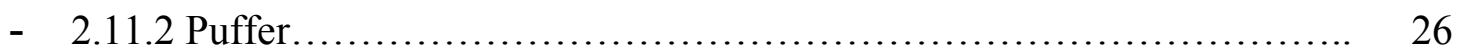

2.12 Primer......................................................... 28

2.13 Materialien................................................. $\quad 29$

$\underline{3 \text { Ergebnisse }}$

3.1 Untersuchung des Effektes von Fas-Ligand, TRAIL, Staurosporin und Stickoxidmetaboliten auf die Zelllinien CG-4 und OLN-93 sowie PMGC-Zellen........................................... 34

- 3.1 .1 Fas........................................................................... 34

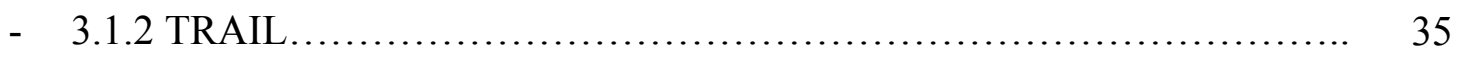

- $\quad 3.1 .3$ Staurosporin.................................................................. 39

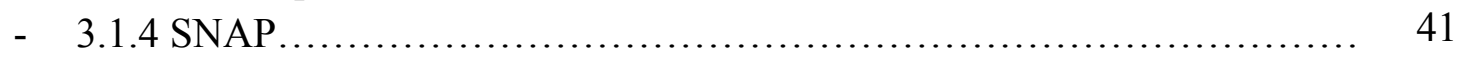

- $\quad 3.1 .5$ Peroxynitrit............................................................ 42

3.2 Analyse der Expression verschiedener Myelingene in unbehandelten CG-4, OLN-93 und primären glialen Zellkulturen...

3.3 Effekte von Staurosporin, SNAP und Peroxynitrit auf die mRNA-Spiegel verschiedener Myelingene in CG-4, OLN-93 und primären glialen Zellen............................................. 44

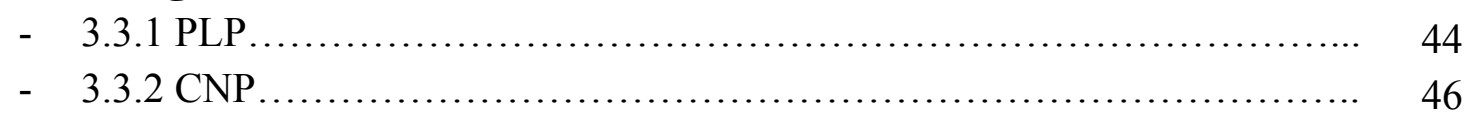


4 Diskussion $\quad 49$

4.1 Wirkung der Zelltodinduktoren TRAIL, FasL und Staurosporin auf oligodendrogliale Zellkulturen.................................. 49

- $\quad 4.1 .1$ TRAIL............................................................. 49

- 4.1 .2 Fas................................................................ 50

- $\quad 4.1 .3$ Staurosporin...................................................... 52

4.2 Wirkung von reaktiven Stickstoffmetaboliten auf oligodendrogliale Zellkulturen..................................... 52

4.3 Veränderung des Genexpressionsmusters der Myelinproteine unter Zugabe toxischer Faktoren...................................... 53

5 Zusammenfassung $\quad 57$

6 Literaturverzeichnis $\quad 59$ 


\section{Abkürzungsverzeichnis}

Abb

ASK1

BCIP

Bid

B16

Bp

BSA

bzw.

${ }^{\circ} \mathrm{C}$

Caspase

CD95

cDNA

CHX

$\mathrm{cm}^{2}$

CNP

CNTF

$\mathrm{CO}_{2}$

DAXX

DD

DED

DIG-DNA

DISC

DMEM

DNA

DNAse

dNTPs

EAE

EDTA

ELISA

eNOS

et al.

Ethidiumbromid

FADD
Abbildung

Apoptosis-signal-regulating kinase 1

5-bromo-4-chloro-3-indolyl phosphate

BH3 Interacting Domain Death Antagonist

Black 6 Mäuse

Basenpaare

Bovines Serumalbumin

beziehungsweise

Grad Celsius

Cysteinyl-Asparaginsäure-Protease

Cell Death Receptor 95

Complementary Desoxyribonucleotide Acid

Cycloheximid

Quadratzentimeter

2',3' Cyclic Nucleotide 3' Phosphodiesterase

Ciliary Neurotrophic Factor

Kohlenstoffdioxid

Death Domain-associated Protein

Death Domain

Death Effector Domain

Digoxigenin gebunden an Nukleotide

Death Inducing Signal Complex

Dulbecco's Modified Eagle Medium

Desoxyribonukleinsäure

Desoxyribonuklease

Desoxyribonukleosidtriphosphate

Experimentielle autoimmune

Enzephalomyelitis

Ethylendiamintetraessigsäure

Enzyme-linked Immunosorbent-Assay

Endotheliale Stickoxidsynthase

et alii

3,8-Diamino-5-ethyl-6-

phenylphenanthridiniumbromid

Fas Associated Death Domain 


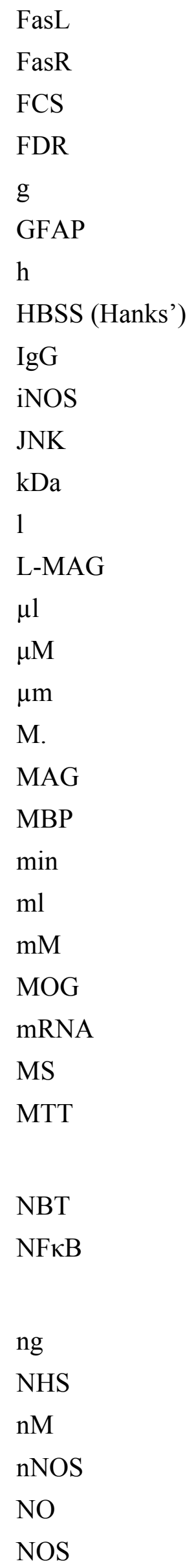

Fas Ligand

Fas Rezeptor

Fetal Calf Serum

Fas Decoy Rezeptor

Gramm

Glial fibrillary acidic protein

Hora, Stunde

Hanks' Balanced Salt Solution

Immunglobulin G

Induzierbare Stickoxidsynthase

c-Jun N-terminal Kinase

Kilodalton

Liter

Long MAG

Mikroliter

Mikromolar

Mikrometer

Morbus

Myelin Associated Glycoprotein

Myelin Basic Protein

Minuten

Milliliter

Millimolar

Myelin Oligodendrocyte Glycoprotein

Messenger-Ribonukleinsäure

Multiple Sklerose

3- [4,5-dimethylthiazol-2-yl]-2,5-

diphenyltetrazoliumbromid

4-nitro-blue tetrazolium chloride

Nuclear Factor "kappa-light-chain-enhancer"

of activated B-cells

Nanogramm

Normal Horse Serum

Nanomolar

Neuronale Stickoxidsynthase

Stickoxid

Stickoxidsynthase 


\begin{tabular}{|c|c|}
\hline $\mathrm{ONOO}^{-}$ & Peroxynitrit \\
\hline OPG & Osteoprotegerin \\
\hline PAGE & Polyacrylamid-Gelelektrophorese \\
\hline PBS & Phosphat Buffered Saline \\
\hline PCR & Polymerase Chain Reaction \\
\hline Pen/Strep & Penicillin/Streptomycin \\
\hline PFA & Paraformaldehyd \\
\hline $\mathrm{pH}$ & potentia Hydrogenii \\
\hline $\mathrm{PKC}$ & Proteinkinase $\mathrm{C}$ \\
\hline PLAD & Pre-ligand assembly domain \\
\hline PLL & Poly-L-Lysin \\
\hline PLO & Poly-L-Ornithin \\
\hline PLP & Proteolipidprotein \\
\hline PMGC & Primary mixed glial culture \\
\hline PNS & Peripheres Nervensystem \\
\hline POD & Peroxidase \\
\hline RNA & Ribonukleinsäure \\
\hline RNase & Ribonuklease \\
\hline RIP & receptor interacting protein \\
\hline RNS & Radikale Stickstoffspezies \\
\hline $\mathrm{rpm}$ & revolutions per minute \\
\hline sFas & Soluble Fas \\
\hline S-MAG & Short MAG \\
\hline SNAP & S-nitroso-N-acetylpenicillamin \\
\hline Taq Polymerase & Polymerase aus Thermophilus aquaticus \\
\hline TBE & TRIS-Borat-EDTA \\
\hline TBS & TRIS-Buffered-Saline \\
\hline TNF & Tumor-Nekrose-Faktor \\
\hline TRAIL & TNF Related Apoptosis Inducing Ligand \\
\hline TRIS & TRIS(hydroxymethyl)-aminomethan \\
\hline TUNEL & TdT-mediated X-dUTP nick end labelling \\
\hline UV & Ultra-violett \\
\hline $\mathrm{V}$ & Volt \\
\hline $\mathrm{W}$ & Watt \\
\hline z.B. & zum Beispiel \\
\hline ZNS & Zentrales Nervensystem \\
\hline
\end{tabular}




\section{Einleitung}

\subsection{Multiple Sklerose (MS)}

Bei der Multiplen Sklerose handelt es sich um eine entzündliche Erkrankung des zentralen Nervensystems (ZNS), bei welcher sich demyelinisierte Läsionen in Gehirn und Rückenmark finden. Sie verläuft individuell sehr variabel, wobei typische Symptome Paresen, Parästhesien, Sehstörungen, Doppelbilder, Schwindel und Blasenfunktionsstörungen sind. Frauen sind häufiger betroffen als Männer.

Man unterscheidet vier verschiedene mögliche Krankheitsverläufe (Lublin und Reingold 1996): Beim schubförmig-remittierenden Verlauf bilden sich die Symptome nach der Phase der akuten Verschlechterung entweder ganz oder zumindest teilweise zurück.

Der sekundär progrediente Krankheitsverlauf zeichnet sich durch eine kontinuierliche Verschlechterung der Symptome aus. Diese Form der MS schließt sich an einen Zeitraum mit schubförmig-remittierendem Verlauf an.

Bei Patienten, die von Beginn der Erkrankung an eine dauerhafte, stetige Verschlechterung zeigen, ohne dass eine klare Abgrenzung in Schübe möglich ist, spricht man von einem primär progredienten Verlauf.

Relativ selten ist die progredient-schubförmige MS, bei welcher sich bei kontinuierlicher Verschlechterung zeitlich begrenzte Phasen finden, in denen der Erkrankungsgrad des Patienten noch weiter zunimmt.

Insgesamt sind die schubförmigen Verläufe mit ca. $80 \%$ der Fälle am häufigsten.

Die Ätiologie der MS ist bislang nicht vollständig geklärt. Man vermutet sowohl eine polygenetische Disposition als auch exogene Einflüsse wie z.B. virale oder bakterielle Infektionen im Kindesalter, welche zu einer fehlgeleiteten Immunantwort gegen Autoantigene führen können.

Auch die Pathogenese der MS ist noch nicht in allen Einzelheiten geklärt.

In der Literatur werden sowohl eine (auto)-immunbedingte Genese als auch eine primäre Schädigung von Oligodendrozyten als Auslöser für die Erkrankung diskutiert (Prat und Antel 2005). Die erste Hypothese geht davon aus, dass aktivierte, gegen ein bisher unbekanntes Antigen gerichtete $\mathrm{CD} 4^{+}$-T-Zellen über die Blut-Hirn-Schranke ins ZNS gelangen, wo sie über Zytokinsekretion phagozytierende Zellen rekrutieren und B-Lymphozyten zur Antikörperbildung stimulieren. Es entsteht eine Entzündungsreaktion, welche Gewebe und Blut-Hirn-Schranke schädigt.

Veränderungen, die für die zweite Hypothese sprechen könnten, werden ebenfalls bei der Entstehung von MS-Läsionen beobachtet: Der Zelltod der Oligodendrozyten als initiales 
Ereignis, evt. nach Infektionen oder Ischämie, führt zu sekundärer Rekrutierung von Immunzellen (Barnett und Prineas 2004).

Histopathologisch weisen alle MS-Läsionen einen Verlust des Myelins, ein entzündliches Infiltrat, einen relativen axonalen Schaden sowie eine reaktive Gliose auf. Bezieht man allerdings Ort der Läsion, die Größe, das Expressionsmuster der Myelinproteine, die Art der Zerstörung der Oligodendrozyten, das Vorhandensein von Immunglobulinen und die Komplementaktivierung mit ein, findet sich ein heterogenes Bild (Lucchinetti et al. 2000). Anhand ihrer Ergebnisse teilten Lucchinetti et al. die akuten MS-Läsionen in vier verschiedene Demyelinisierungsmuster ein. Dabei zeigen Patienten mit mehreren Herden immer das gleiche histologische Muster.

Muster I und II zeigen ein ähnliches histologisches Bild, von dem man annimmt, dass autoimmune Prozesse bei seiner Entstehung eine Rolle spielen. Die demyelinisierten Läsionen finden sich perivenös. In den Läsionen finden sich Infiltrate aus Makrophagen und T-Zellen. Der wesentliche Unterschied zwischen Muster I und II besteht in der Ablagerung von aktiviertem Komplement (C9neo) und Immunglobulinen (vor allem IgG) bei Muster II. Dies geschieht in einem Maße, welches die in allen Mustern zu findende Anreicherung von Immunglobulinen auf Grund der entzündungsbedingten Durchlässigkeit der Blut-HirnSchranke deutlich übersteigt. Bei Muster I geht man davon aus, dass von aktivierten Makrophagen freigesetzte Substanzen wie z.B. TNF $\alpha$ die entscheidende Rolle spielen. Bei beiden Demyelinisierungsmustern kommt es in den zerstörten Myelinscheiden zu einem Verlust sämtlicher Myelinproteine. In der Studie von Lucchinetti et al. (2000) ist Muster II das am häufigsten vorkommende.

Bei Muster III und IV scheint ein degenerativer Prozess im Vordergrund zu stehen. Die Läsionen entstehen nicht durch eine Zerstörung des Myelins, sondern durch eine Degeneration der Oligodendrozyten; der Verlust des Myelins ist also ein sekundärer Prozess. Auch in Muster III zeigt sich wie in den beiden ersten ein aus Makrophagen und T-Zellen sowie Mikroglia bestehendes entzündliches Infiltrat, allerdings fehlen Komplement- und Antikörperablagerungen. Die Herde sind unscharf begrenzt. Auffällig bei Muster III ist vor allem eine andere Ausprägung der Myelinproteine in den zerstörten Scheiden als bei den übrigen Mustern: Es findet sich hier der fast ausschließliche Verlust der Myelinproteine MAG und CNP, während die anderen Proteine weiterhin vorhanden oder sogar verstärkt nachweisbar sind. An der Grenze der aktiven Plaque findet sich eine verstärkte Degeneration von Oligodendrozyten, z.T. sogar bis in die angrenzende, normal erscheinende weiße 
Substanz; im Inneren der Plaque befinden sich kaum noch Oligodendrozyten. Als mögliche Ursache für dieses Muster wird eine distal bedingte Oligodendrogliopathie diskutiert.

Das vierte Demyelinisierungsmuster, das bisher nur in einer geringen Anzahl von Patienten mit einem primär-progredienten Krankheitsverlauf gefunden worden ist, ist durch eine primäre Zerstörung der Oligodendrozyten am Rand der Läsionen in der weißen Substanz sowie durch einen fast vollständigen Verlust von Oligodendrozyten im Läsionszentrum gekennzeichnet. Entzündungsvermittelnde Zellen sind auch hier T-Zellen; außerdem spielen aktivierte Makrophagen und Mikroglia eine Rolle. Anlagerungen von Antikörpern und Komplement wird nicht gefunden.

\subsection{Das Myelin}

Die Oligodendrozyten bilden und erhalten im ZNS die Markscheiden. Diese bestehen aus Myelin, einer stark lipidhaltigen Membran, mit welcher die Oligodendrozyten Axone umwickeln und sie elektrisch isolieren, um die saltatorische Erregungsüberleitung zu garantieren.

Die Entwicklung von myelinisierten Nervenfasern stellt eine besondere evolutionäre Errungenschaft dar. Ohne sie wäre eine Ausbildung höher entwickelter Nervensysteme nicht möglich gewesen: Auf Grund der fehlenden saltatorischen Erregungsleitung erreichen unmyelinisierte Axone lediglich Leitungsgeschwindigkeiten von $1 \mathrm{~m} / \mathrm{s}$. Da physikalisch gesehen die Fortleitungsgeschwindigkeit der Erregung dem Radius des Axons proportional ist, benötigen unmyelinisierte Axone also einen erheblich größeren Raum- und Energieaufwand, um ähnliche Fortleitungsgeschwindigkeiten wie myelinisierte Axone, welche $100 \mathrm{~m} / \mathrm{s}$ schnell leiten, zu erreichen.

Der Aufbau von Myelin unterscheidet sich von dem anderer Membranen. Im Myelin macht der Lipidanteil über 70\% aus (Trockengewicht), während der Proteinanteil mit nur 30\% (Trockengewicht) im Vergleich zu anderen Membranen relativ gering ist.

Auf die verschiedenen Myelinproteine wird in dieser Arbeit in einem gesonderten Kapitel eingegangen.

Entsprechend den unmyelinisierten Nodien, die auch als Ranviersche Schnürringe bezeichnet werden und an denen das Potential der saltatorischen Erregungsleitung generiert wird, bezeichnet man die myelinisierten Bereiche des Axons als Internodien. Im Gegensatz zum peripheren Nervensystem (PNS), wo die Schwannzellen immer nur ein Axon myelinisieren, ist ein Oligodendrozyt in der Lage, viele Markscheiden auszubilden. Die Internodien bestehen aus kompaktem Myelin; d.h. der Fortsatz des Oligodendrozyten wickelt sich hier so fest um 
das Axon, dass elektronenmikroskopisch im Querschnitt eine Spirale entsteht, in der die ohne Zytoplasma direkt einander anliegenden Membranen zwei Linien bilden. Die aufeinander liegenden extrazellulären Seiten der Plasmamembran bilden die sogenannte ,intraperiod line“, die zytoplasmatischen Seiten die ,major dense line“. Die Kompaktierung des Myelins beginnt schon, während sich die ersten beiden Spiralen bilden.

Die unterschiedlichen Strukturen des Myelins zeigen bereits, dass es sich beim Myelin nicht einfach um eine Erweiterung der Plasmamembran der Oligodendrozyten handelt, sondern dass es ein komplexeres System darstellt. Von großer Wichtigkeit in diesem System ist die korrekte Sortierung der verschiedenen Proteine, welche zum Teil nur an ganzen bestimmten Orten benötigt werden wie z.B. das PLP (Proteolipidprotein) im kompakten Myelin.

\subsection{Die Myelinproteine}

\subsubsection{MBP (Myelin Basic Protein)}

Die MBPs machen 30-40\% des Proteinbestandteils im Myelin aus. Sie bilden eine Familie bestehend aus verschiedenen Isoformen, welche durch alternatives splicing der mRNA entstehen. Dabei unterscheidet man zwei Untergruppen der Proteine: die classic MBPs und die golli MBPs. Beim Menschen liegt das sogenannte „golli-MBP“ Gen auf Chromosom 18. Die Gruppe der classic MBPs besteht aus mindestens sechs verschieden gespleißten Isoformen zwischen 14 und $21 \mathrm{kDa}$, welche sich aus verschiedenen Kombinationen von sieben Exons zusammensetzen. In höchster Konzentration in den myelinbildenden Zellen ist die 18,5-kDa-Form der classic MBPs vorhanden. Die Expression ist entwicklungsstadienabhängig.

Die drei golli MBPs werden im Gegensatz zu den classic MBPs nicht nur in myelinbildenden Zellen des ZNS und PNS gebildet, sondern auch z.B. von einigen Neuronen oder Zellen des Immunsystems. Sie scheinen keine Rolle bei der Strukturerhaltung des Myelins zu haben, dagegen ist eine Funktion bei Remyelinisierungsversuchen und Fortsatzbildung wahrscheinlich (Filipovic et al. 2002; Campagnoni AT und Campagnoni CW 2004).

Die Funktion des classic MBP liegt in der Aufrechterhaltung der Struktur der Myelinscheiden. Da diese Aufgabe aber auch eine einzige Isoform bewältigen kann (Kimura et al. 1998), ist der Grund für die Expression unterschiedlicher Proteine unklar. 


\subsubsection{PLP (Proteolipid Protein)}

Ebenso wie beim MBP existieren auch beim PLP verschiedene Isoformen. Hier handelt es sich um das PLP selbst und um die kleinere Isoform DM20, welche durch alternatives splicing in Exon 3 entsteht. DM20 wird von oligodendroglialen Vorläuferzellen exprimiert, während PLP sich in reifen Oligodendrozyten findet (Schindler et al. 1990)

Das Gen, das für die beiden Proteine codiert, liegt auf dem X-Chromosom und ist somit ein sogenanntes single copy gene, d.h. dass für ein Protein, welches mengenmäßig ungefähr die Hälfte der Myelinproteine ausmacht, nur ein Allel vorhanden ist.

Außer im ZNS findet sich das Genprodukt noch in PNS, Herz, Milz, Thymus und Lymphknoten (Campagnoni AT und Skoff 2001).

Neben der Fähigkeit zur Membranstabilisierung im Myelin wird weiterhin ein Zusammenhang zwischen der Expression von PLP und der Apoptoserate von Oligodendrozyten diskutiert (Skoff et al. 2004 a), wobei bei Zellen, die nur wenig oder kein PLP exprimieren, die Apoptoserate geringer ist als bei Kontrollen mit normaler Expressionsrate.

\subsubsection{MAG (Myelin-Associated Glycoprotein)}

Das Gen für MAG liegt beim Menschen auf Chromosom 19, bei der Maus auf Chromosom 7. Durch alternatives Spleißen entstehen die beiden Isoformen S-MAG und L-MAG, welche sich in der Länge des C- terminalen Endes unterscheiden. L-MAG findet sich vor allem im ZNS, während im PNS S-MAG dominiert.

MAG findet sich in myelinbildenden Zellen nach Beginn der Kompaktierung des Myelins lediglich periaxonal und nur in geringer Konzentration im nicht-kompakten Myelin (Bartsch U et al. 1989).

MAG scheint eine Funktion ganz zu Beginn der Myelinisierung zu haben, da es als erstes Protein in die Fortsätze der Zelle transportiert wird und dieser Transport noch vor Kontakt mit dem Axon stattfindet. Tiere, denen das MAG-Gen fehlt, zeigen einen verzögerten Beginn der Myelinisierung im ZNS und es findet sich sowohl überflüssiges Myelin als auch eine gesteigerte Anzahl an unmyelinisierten Axonen mit einem reduziertem axonalen Durchmesser (Bartsch S et al. 1997, Montag et al. 1994). Bei diesen Tieren zeigen auch die Oligodendrozyten Veränderungen: Es kommt zu einer Dystrophie der Fortsätze (Lassmann et al. 1997; Weiss et al. 2000). Diese Veränderungen sind evt. Ursache der gestörten Kommunikation zwischen Axonen und Oligodendrozyten. 


\subsubsection{MOG (Myelin Oligodendrocyte Glycoprotein)}

MOG macht mit 0,05-1\% den geringsten Anteil des Myelinproteingehaltes aus.

Das Gen für dieses Myelinprotein liegt beim Menschen auf Chromosom 6 und enthält 8 Exone. Durch alternatives Spleißen entstehen verschiedene mRNA-Varianten.

MOG befindet sich in der äußersten Schicht der Myelinlamellen an der Oberfläche (Brunner et al. 1989). Die Funktion von MOG ist bislang unklar. Mausmutanten mit fehlender Expression von MOG zeigen eine normale Entwicklung sowie einen regelrechten Aufbau des Myelins und der Axone (Delarasse et al. 2003). Auch die Frage nach einer Rezeptorfunktion stellt sich im Angesicht einer extrazellulären und einer hochkonservierten zytoplasmatischen Domäne. Ein Ligand für den potentiellen MOG-Rezeptor ist allerdings noch nicht gefunden worden.

Von großem Interesse im Hinblick auf demyelinisierende Erkrankungen des ZNS ist die extrazelluläre Ig-ähnliche Domäne. Während die anderen Myelinproteine gegen die Bindung von Antikörpern schon durch ihre Lage entweder im kompakten Myelin oder in den zum Axon hin gelegenen Lamellen geschützt sind, ist hier ein direkter Angriff auf die Myelinscheide durch Antikörper möglich.

In weiteren Experimenten zeigte sich, dass durch Sensibilisierung mit MOG bei verschiedenen Säugern eine experimentelle autoimmune Enzephalomyelitis (EAE) mit TZell- und demyelinisierender Antikörperantwort auslösbar ist (Storch et al. 1998). Diese Form der EAE ist ein sehr häufig benutztes Tiermodell für die MS.

\subsubsection{CNP (2’3’ Cyclic Nucleotide 3’ Phosphodiesterase)}

CNP wird wegen seiner hohen Spezifität als Marker für Oligodendrozyten und Myelin eingesetzt. Es existieren zwei Isoformen: CNP 1 und CNP 2.

CNP findet sich zum einen im Zytoplasma, wo eine Verbindung mit Bestandteilen des Zytoskeletts wie Aktinnetzwerken (DeAngelis und Braun 1996) und Mikrotubuli (Bifulco et al. 2002) beschrieben wurde. Des Weiteren wird CNP 2 in die Mitochondrien transportiert und ist hier wahrscheinlich an der Metabolisierung von RNA und Nukleotiden beteiligt (Lee J et al. 2006). Das Protein zeigt eine strukturelle Ähnlichkeit mit RNA-prozessierenden Enzymen.

Beide Isoformen zeigen enzymatische Aktivität; sie hydrolysieren 2'-3'-zyklische Mononukleotide zu 2'-Nukleotiden. 
Weitere Funktionen scheinen außerdem wahrscheinlich, da CNP früh in der Entwicklung in den Vorläufern der myelinisierenden Zellen sowie mit geringerer Expression auch in nichtmyelinisierenden Zellen wie z.B. Erythrozyten exprimiert wird.

\subsection{Zelllinien}

Die Versuche für diese Arbeit wurden außer an primären Mauskulturen auch an den Zelllinien CG-4 und OLN-93 durchgeführt, die in diesem Kapitel kurz näher beschrieben werden sollen.

\subsubsection{CG-4}

Die Zelllinie CG-4 wurde erstmals 1992 von J. Louis beschrieben. Sie ist spontan aus bipotentialen Vorläuferzellen aus Primärkulturen des Ratten-ZNS entstanden, welche sowohl zu Oligodendrozyten als auch zu Typ-II-Astrozyten differenzieren können. Man bezeichnet diese Vorläuferzellen deshalb als O-2A-Zellen.

Undifferenzierte CG-4-Zellen sind bipolar, mit steigender Dichte und sinkender Wachstumsrate werden sie multipolar. Wie die O-2A-Zellen differenzieren die CG-4-Zellen zu multipolaren A2B5- und GFAP (glial fibrillary acidic protein) - positiven Typ-IIAstrozyten, wenn sie in Medium kultiviert werden, welches hohe Konzentrationen Serum oder CNTF (ciliary neuronotrophic factor) enthält (Hughes et al. 1988). Ohne Serum bzw. mit nur geringen Serumkonzentrationen kultiviert und ohne die Zugabe von proliferationsfördernden Medienzusätzen (wie z.B. dem Überstand der neuronalen Zelllinie B104), differenzieren sie zu Oligodendrozyten. Die Zellen bilden verzweigte Fortsätze aus und während der Oberflächenmarker A2B5 weniger stark exprimiert wird, finden sich nun Galactocerebroside und verschiedene Myelinproteine.

Man findet bei den CG-4-Zellen einen normalen Karyotyp; außerdem spricht die Tatsache, dass die Zellen ohne Zusatz von Mitogenen wie B104-Medium nicht proliferieren, dafür, dass es sich bei CG-4-Zellen nicht um transformierte Tumorzellen handelt.

Die in-vitro-Experimente der vorliegenden Arbeit wurden an zu Oligodendrozyten differenzierten CG-4-Zellen durchgeführt, welche nach $24 \mathrm{~h}$ mit dem jeweiligen Zelltodinduktor versetzt worden sind.

\subsubsection{OLN-93}

Die Zelllinie OLN-93 wurde 1996 von Richter-Landsberg und Heinrich etabliert. In glialen Rattenhirnprimärkulturen traten spontan transformierte Zellen auf, welche morphologisch den 
bipolaren O-2A-Zellen ähneln. Bei geringer Dichte kultiviert, zeigen sie ein bipolares Aussehen mit langen Ausläufern; mit zunehmender Dichte entstehen Zellhaufen, welche durch lange dünne Fortsätze verbunden sind.

Die Zellen haben keine astrozytären Eigenschaften, so werden z.B. weder das Intermediärfilamentprotein Vimentin noch GFAP exprimiert. Auch der Oberflächenmarker A2B5 wurde nicht nachgewiesen. Oligodendrozytäre Eigenschaften zeigen sich in der Expression von Galactocerebrosiden sowie verschiedener Myelinproteine des ZNS wie z.B. einer Isoform von MBP und des Weiteren L-MAG, S-MAG, PLP und DM20.

Zusammenfassend lässt sich sagen, dass es sich bei der Zelllinie OLN-93 um Zellen handelt, die von der Entwicklung her zwischen O-2A-Zellen und reifen Oligodendrozyten liegen. Sie exprimieren bereits verschiedene Myelinproteine, diese verteilen sich aber noch diffus. Sie entsprechen etwa 5-10 Tage (postnatal) alten Rattenoligodendrozyten.

\subsection{Zelltodinduktoren}

Im Rahmen dieser Arbeit sind Zellstimulationen mit fünf Reagenzien durchgeführt worden, von denen man annimmt, dass sie eine Rolle beim oligodendroglialen Zelltod in MS-Läsionen spielen könnten. Die Zelllinien CG-4 und OLN-93 sowie primäre gemischte Gliazellkulturen sind mit den reaktiven Stickstoffverbindungen Stickstoffmonoxid und Peroxynitrit, den Apoptoseliganden TRAIL und Fas sowie dem Proteinkinasehemmer Staurosporin behandelt worden.

\subsubsection{Stickoxid und Peroxynitrit}

Stickstoffmonoxid (NO; auch Stickoxid) und Peroxynitrit $\left(\mathrm{ONOO}^{-}\right)$gehören zu den reaktiven Stickstoffverbindungen (RNS: reactive nitrogen species). Sie haben neben vasodilatatorischen Eigenschaften und Funktionen als Neurotransmitter (beides durch NO vermittelt) einen toxischen Effekt auf eine Vielzahl von unterschiedlichen Zellen.

Stickoxid entsteht aus der Reaktion der Aminosäure L-Arginin mit molekularem Sauerstoff, wobei Citrullin und ein Molekül Stickoxid entsteht. Diese Oxidation wird durch das Enzym Stickoxidsynthase (NOS) katalysiert (Knowles und Moncada 1994). Es sind bisher drei Isoformen dieses Enzyms bekannt: Die endotheliale Isoform (eNOS), die neuronale Isoform (nNOS) und die induzierbare Isoform (iNOS). Man findet letztere u.a. in Zellen des Immunsystems wie Makrophagen und Mikroglia, in denen das Enzym Calcium-unabhängig 
große Mengen NO auf Reize wie Entzündungen hin produziert, wie sie z.B. in MS-Läsionen auftreten (Liu et al. 2001, Jack et al. 2007).

In vitro führte NO über morphologische Veränderungen, mitochondriale Dysfunktion und DNA-Schäden zu Zelltod von Rattenoligodendrozyten (Mitrovic et al. 1994). In der EAE konnte eine erhöhte Expression der iNOS nachgewiesen werden (Cross et al. 1996). Durch Messung der Nitrit- und Nitratwerte im Hirnparenchym und Liquor von MS-Patienten konnte gezeigt werden, dass bei ihnen die Produktion von NO im Vergleich zu Gesunden erhöht ist (Brundin et al. 1999, Rejdak et al. 2004). Post mortem zeigte sich in MS-Läsionen eine erhöhte iNOS-Konzentration (Bagasra et al. 1995) sowie Nitrotyrosinkonzentration (Cross et al. 1998; Bagasra et al. 1995), was ein Hinweis für erhöhte Peroxynitritkonzentrationen ist.

Die Wirkung von NO beruht u.a. auf einer reversiblen Hemmung des Komplexes IV der Atmungskette (Zytochrom-C-Oxidase). Dies führt $\mathrm{zu}$ einer vermehrten Produktion von Superoxidanionen und es kommt zur Bildung von Peroxynitrit $\left(\mathrm{NO}+\mathrm{O}_{2}^{-} \rightarrow \mathrm{ONOO}^{-}\right.$). Physiologischerweise entstehen Superoxidanionen auch an den Komplexen I (NADHDehydrogenase) und III (Zytochrom-Reduktase) der Atmungskette sowie u.a. bei phagozytierenden Zellen und Fibroblasten an membranassoziierten NADPH-Oxidasen.

Die Atmungskette der Zelle wird irreparabel geschädigt, da Peroxynitrit die Komplexe I, II und III irreversibel hemmt (Lizasoain et al. 1996).

Es kommt neben der Schädigung von Enzymen mit Eisen-Schwefel-Zentrum zur Nitrierung von Tyrosinresten. Außerdem werden Lipide durch Peroxidation geschädigt (van der Veen et al. 1997).

Eine Beteiligung von Stickoxid und Peroxynitrit bei Entstehung und Verlauf der MS ist durchaus denkbar, da NO bzw. Peroxynitrit viele molekulare und zelluläre Vorgänge beeinflussen können, die bei der MS eine Rolle spielen könnten wie die direkte Schädigung der Oligodendrozyten, die Modulation des Immunsystems und mögliche Effekte auf die BlutHirn-Schranke.

\subsubsection{Fas}

Der Fas-Rezeptor (FasR), an den der dreiteilige Fas-Ligand (FasL) bindet, besteht aus drei Domänen: Vom N-terminalen Ende aus gezählt stehen die zweite und dritte Domäne in Kontakt mit dem Liganden, während die erste eine sogenannte pre-ligand assembly domain (PLAD) bildet, welche man auch beim TRAIL-Rezeptor findet und die für eine Verbindung einzelner Rezeptoren zu (im Fall von TRAIL und Fas) Homo- z.T. auch Heterotrimeren sorgt, bevor der eigentliche Ligand gebunden wird. 
Nach Bindung des Liganden rekrutiert der Rezeptor verschiedene Adapterproteine (s. Review von Choi und Benveniste 2004). Zu ihnen gehört FADD (Fas Associated Death Domain). Das Protein trägt N-terminal eine Todesdomäne (DD), mit welcher es an die DD des Rezeptors bindet und C-terminal eine DED (Death Effector Domain), über welches es Procaspase 8 rekrutiert, die ebenfalls eine DED besitzt. Die Procaspase wird nach Dimerisierung autokatalytisch in ein aktives heterodimeres Enzym gespalten und aktiviert die Caspase-Kaskade sowie den mitochondrialen Signalweg über die Spaltung von Bid (Li H et al. 1998).

Neben dem u.a. Apoptose auslösenden Rezeptor finden sich drei weitere FasL bindende Rezeptoren: Zum einen ein durch alternatives Spleißen entstehender löslicher Rezeptor, so genanntes soluble Fas (sFas) (Cascino et al. 1995), außerdem ein Decoy-Rezeptor (TR6), dessen Aktivierung keine Apoptose auslöst (Connolly et al. 2001). Als drittes gibt es den sogenannten Fas-Decoy-Rezeptor (FDR), welcher evt. mit den anderen Typen gemischte Rezeptorkomplexe bildet und dadurch die Apoptoseeinleitung hemmt, da er zwar die gleiche extrazelluläre Domäne ausbildet, aber keine DD besitzt (Jenkins et al. 2000). Alle treten somit als kompetitive Inhibitoren für die FasR-vermittelte Apoptose in Erscheinung.

Neben der Apoptose-auslösenden Signalkaskade über die Caspasen wird durch den FasR über DAXX und ASK1 der JNK-Signalweg aktiviert, sowie über RIP der Transkriptionsfaktor

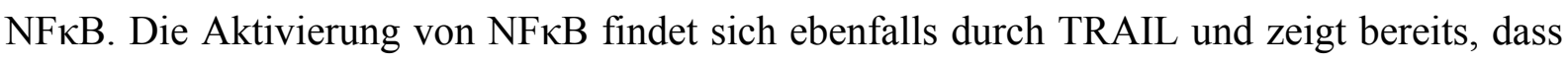
neben dem viel diskutierten apoptotischen Effekt von FasR noch weitere Funktionen vorhanden sind wie z.B. die Synthese anti-apoptotischer Proteine.

Während der FasR von vielen verschiedenen Zellen exprimiert wird, wird der FasL mit juxtakriner Aktivität zumeist von Zellen des Immunsystems wie aktivierten T-Zellen und NKZellen freigesetzt und spielt z.B. eine Rolle bei der durch zytotoxische T-Zellen vermittelten Eliminierung von virusinfizierten Zellen. Da sich auch im ZNS einige wenige T-Zellen finden, könnte die Expression von FasL im ZNS Teil des Schutzmechanismus des ZNS vor potentiell autoreaktiven Immunzellen sein. Die Expression von FasL auf Endothelzellen verhindert eventuell die Migration von Entzündungszellen in das ZNS (Walsh und Sata 1999).

Oligodendrozyten sind wie die meisten Zellen des ZNS sensibel für Fas und sterben nach Aktivierung des FasR.

Nach Zugabe von FasL kommt es z.B. bei der Oligodendrozytenzelllinie MO3.13 zu einer Aktivierung der extrinsischen apoptotischen Signalkaskade und zu einem caspaseabhängigen 
Zelltod (Li W et al. 2002). Mäuse, in denen FasR selektiv in Oligodendrozyten fehlt, erweisen sich als relativ resistent gegen EAE, einem Tiermodell der Multiplen Sklerose (Hövelmeyer et al. 2005). In MS-Läsionen ist die Expression von FasR in Oligodendrozyten erhöht (D'Souza et al. 1996).

Bei der Multiplen Sklerose spielt Fas wahrscheinlich zwei verschiedene Rollen: Im entzündlich veränderten Gehirn sorgt es einerseits für die Apoptose von T-Zellen, deutlich zu sehen auch in Versuchen, in denen es nach Injektion von FasL durch Tod der T-Zellen zur Verbesserung der EAE kam (Zhu et al. 2002); andererseits können den FasR exprimierende Gliazellen, wie z.B. die Oligodendrozyten, ebenfalls durch Binden des FasL geschädigt werden.

\subsubsection{TRAIL}

TRAIL (Tumour necrosis factor apoptosis inducing ligand) ist ein Apo-2 Ligand und gehört zur gleichen Familie wie die TNF-Liganden und der Fas-Ligand, mit welchem es stark homolog ist. Der dreiteilige Aufbau des Rezeptors ist jenem für Fas sehr ähnlich.

Beim Menschen finden sich bislang fünf Rezeptoren: DR 4 und 5, DcR 1 und 2 sowie Osteoprotegerin.

DR 4 (TRAIL-R1) und DR 5 (TRAIL-R2) weisen eine fast 60\%ige Homologie auf. DR 5 wird in vielen Geweben exprimiert, besonders stark in aktivierten Lymphozyten und nach Therapie mit DNA-schädigenden Krebsmedikamenten oder $\gamma$-Strahlen. Beide Rezeptoren lösen nach Bindung des Liganden sowohl in entarteten als auch in vielen gesunden Zellpopulationen, wie z.B. in Oligodendrozyten, Zelltod aus.

Zwei weitere Rezeptoren sind so genannte „decoy receptors 1 und 2“ (TRAIL-R3 und TRAIL-R4). Diese Rezeptoren können zwar TRAIL binden, aufgrund einer fehlenden funktionellen Todesdomäne jedoch keinen Zelltod auslösen (Kimberley und Screaton 2004) Der fünfte Rezeptor ist Osteoprotegerin (OPG), welches die Entwicklung und Aktivität von Osteoklasten reguliert. Seine Funktion als Rezeptor für TRAIL ist bislang unverstanden. TRAIL scheint nach bisherigen Erkenntnissen ähnliche intrazelluläre Signalwege wie TNFund Fas-Liganden über die Rezeptoren mit intrazellulärer Todesdomäne zu aktivieren. Die Bildung des Death Inducing Signaling Complex (DISC) und die nachfolgende Aktivierung der Caspase-Kaskade führen zum Zelltod (Kischkel et al. 2000). Allerdings sind zellspezifische Signalwege nicht auszuschließen. 
Weiterhin sind noch andere Signalkaskaden beschrieben worden, welche die Aktivierung von Transkriptionsfaktoren wie $\mathrm{NF \kappa B}$ einschließen und nicht $\mathrm{zu}$ Zelltod führen müssen (Kimberley und Screaton 2004).

In humanen Oligodendrozyten wird Zelltod über TRAIL-R1 ausgelöst (Matysiak et al. 2002) und es kommt vor der Dysfunktion der Mitochondrien zur Aktivierung des JNK-Signalweges (Jurewicz et al. 2002)

Neben der Möglichkeit, dass TRAIL bei Erkrankungen wie der MS nach der Freisetzung aus z.B. Makrophagen direkt die Oligodendrozyten schädigt, bleibt die zweite These von dem indirekten Einfluss auf das Krankheitsgeschehen in Form eines inhibitorischen Effektes auf aktivierte T-Zellen bei der EAE und somit evt. Ausübung einer protektiven Funktion bei autoimmunbedingten Entzündungen im ZNS (Hilliard et al. 2001)

\subsubsection{Staurosporin}

Staurosporin wurde 1977 aus Streptomyces staurosporeus isoliert (Nakano und Omura 2009) und hat eine apoptotische Wirkung auf viele verschiedene Zellarten. Des Weiteren zeigt es antifungale, nicht aber antibakterielle Eigenschaften.

Das Molekül besteht aus einer Zuckereinheit sowie einer planaren heterozyklischen IndolCarbazol-Untereinheit. Staurosporin hat eine inhibitorische Wirkung auf Proteinkinasen durch Bindung an die katalytischen Anteile. Es kommt somit zur kompetitiven Hemmung und Blockade der Enzyme.

$\mathrm{Zu}$ nennen sind in diesem Zusammenhang die Hemmung der Proteinkinase C (PKC), welche durch verminderte Spaltung von Bid in Fas-stimulierten Zellen diese vor Apoptose schützt (Scaffidi et al. 1999). Außerdem hemmt Staurosporin die IкB-Kinase, einen Regulator des anti-apoptotischen Proteins NFkB (Peet und Li 1999). Auch eine Hemmung der Akt/PKB, welche die Kaspase-Kaskade auf verschiedenen Leveln hemmt (Masure et al. 1999), ist beschrieben worden (Stepczynska et al. 2001).

In dieser Arbeit ist Staurosporin als Kontrolle verwendet worden. 


\subsection{Fragestellung und Zielsetzung}

Aus früheren Arbeiten der Abteilung für Neuropathologie der Universität Göttingen ist bekannt, dass es nach Zugabe von NO oder $\mathrm{ONOO}^{-} \mathrm{zu}$ der Zelllinie OLN-93 zu einer Heraufregulation von PLP-mRNA und einer Herunterregulation von CNP-mRNA kommt (Höff 2006). Eine ähnliche differenzielle Expression von Myelinproteinen kann auch in einer Subgruppe von MS-Läsíonen gefunden werden. In der vorliegenden Arbeit sollen folgende Fragen geklärt werden:

1. Führen andere potentiell schädigende Faktoren, wie z.B. TRAIL, FasL oder Staurosporin $\mathrm{zu}$ Zelltod in den Zelllinien OLN-93 und CG-4 sowie primären gemischten glialen Zellkulturen?

2. Wie verändert sich die Expression von PLP und CNP sowie anderer Myelinproteine (MAG, MOG, MBP) nach Zugabe dieser zelltodauslösenden Faktoren?

3. Sind diese Veränderungen spezifisch für OLN-93-Zellen oder lassen sie sich auch in anderen oligodendroglialen Zelllinien (CG-4-Zellen) oder primären gemischten glialen Kulturen der Maus nachweisen? 


\section{Material und Methoden}

\subsection{Prinzipieller Ablauf der Versuchsreihen}

Die zu behandelnden Zellen sind in Kavitäten (Wells) für MTT-Test, Nukleosomen-ELISA und TUNEL-Färbung bzw. in Zellkulturflaschen $\left(75 \mathrm{~cm}^{2}\right)$ für RNA- und Proteinextraktion ausgesät worden. Nach Stimulation wurden die Zellen für 24, 48 oder 72 Stunden (abhängig vom Zelltodinduktor) inkubiert. Nach Ablauf der Inkubationszeit sind die entsprechenden Tests zur Untersuchung der mitochondrialen Respiration und des Zelltodes durchgeführt bzw. die Zellen geerntet worden.

Aus den Zellpellets wurden die RNA extrahiert, in cDNA umgeschrieben und mit dieser cDNA PCRs durchgeführt: Zunächst PCRs, um festzustellen, ob die gewünschte mRNA exprimiert wurde; danach bei positivem Ergebnis quantitative Real Time PCRs.

\subsection{Zellkultur}

Die in der Zellkultur durchgeführten Arbeiten wurden unter sterilen Bedingungen unter einer Zellkulturbank durchgeführt. Verwendete Gegenstände und Substanzen waren entweder steril verpackt oder wurden sterilisiert bzw. autoklaviert.

Im Folgenden soll eine kurze Übersicht über die verwendeten Zellen und ihre Kulturbedingungen gegeben werden. Versuche sind mit CG-4-Zellen, welche 24 Stunden mit Differenzierungsmedium inkubiert worden waren, sowie OLN-93-Zellen und primären murinen Gliazellkulturen (Mäuse: C57Black 6 (C57Bl/6); 0 bis 3 Tage alt) durchgeführt worden.

\section{CG-4-Zellen:}

CG-4-Zellen sind im undifferenzierten Zustand gehalten und passagiert worden. Ihr Medium bestand aus 70\% N1-Medium mit Biotin und 30\% Medium der neuronalen Zelllinie B104. Wie die differenzierten Zellen sind sie bei $37^{\circ} \mathrm{C}$ mit einem $\mathrm{CO}_{2}-$ Gehalt von $5 \%$ inkubiert worden.

Experimente mit CG-4-Zellen sind durchgeführt worden, nachdem die Zellen für 24 Stunden mit dem Differenzierungsmedium versetzt worden waren. Dieses bestand aus N1-Medium mit Biotin plus 2\% FCS (fetales Kälberserum). Die ausgesäte Zellzahl betrug $40 \quad 000$ Zellen/Kavität der 24er Platte sowie 1500000 Zellen/Zellkulturflasche $\left(75 \mathrm{~cm}^{2}\right)$. 


\section{OLN-93-Zellen:}

OLN-93-Zellen sind im Inkubator bei $37{ }^{\circ} \mathrm{C}$ mit $10 \% \mathrm{CO}_{2}-$ Gehalt inkubiert worden. Ihr Medium beruht auf einer DMEM-Basis plus 10\% FCS plus 1\% Penicillin/Streptomycin. Ausgesät wurden 6250 Zellen/Kavität einer 24er Platte und 234370 Zellen/Zellkulturflasche $\left(75 \mathrm{~cm}^{2}\right)$.

\section{Primäre gemischte Gliazellkulturen:}

Vorgehen zur Herstellung: s. unten.

Die Zellen sind bei $37{ }^{\circ} \mathrm{C}$ mit $5 \% \mathrm{CO}_{2}$ inkubiert worden. Ihr Medium bestand aus DMEM plus 10\% NHS (normal horse serum) plus 1\% Penicillin/Streptomycin. Zum Differenzieren wurde DMEM Medium plus Additive verwendet (genaue Angaben s. „Medien und Puffer").

\subsubsection{Passagieren von OLN-93}

Das verbrauchte Medium wird aus der Flasche abgezogen und die Zellen mit $5 \mathrm{ml}$ PBS gewaschen. Nach dem Absaugen von PBS werden die Zellen für ca. 1 min mit $1 \mathrm{ml}$ Trypsin versetzt und während dieser Zeit in den Inkubator gestellt. Das Trypsin wird nach Ablauf der Inkubationszeit mit Medium verdünnt und die Zellen durch Auf- und Abpipettieren vom Boden der Flasche gelöst. Sie werden in ein 50-ml-Zentrifugenröhrchen überführt und für 5 min bei 1200 rpm zentrifugiert. Dann wird der Überstand abgesaugt, die Zellen werden durch kurzes Aufkratzen aus dem Pelletverband gelöst und in frischem Medium resuspendiert. Nach Befüllen der neuen Flasche mit $5 \mathrm{ml}$ Medium werden 1-2 Tropfen der Zellsuspension in die neue Flasche gegeben.

\subsubsection{Passagieren von CG-4}

Die neuen Flaschen werden über Nacht mit PLO beschichtet (Verhältnis steriles Aqua bidest: PLO 5:1). Vor dem Passagieren werden sie dreimal mit sterilem Aqua bidest gewaschen und anschließend für 10 min mit UV-Licht bestrahlt.

Die CG-4-Zellen werden nach Abziehen des Mediums mit Hilfe des Enzyms Biotase vom Boden gelöst. Sie werden dafür für ca. 20 min inkubiert. Dann wird das Enzym mit Medium verdünnt, die Zellen in ein 50-ml-Zentrifugenröhrchen überführt und für 5 min bei $1200 \mathrm{rpm}$ zentrifugiert. Das verbrauchte Medium wird abgesaugt, die Zellen werden kurz aufgekratzt 
und in frischem Medium resuspendiert. Nach Befüllen der neuen Flaschen mit Medium werden ca. 3-4 Tropfen Suspension dazu gegeben.

\subsubsection{Zählen und Aussäen der Zellen}

Die Zellen werden wie beim Passagieren vom Boden der Zellkulturflasche gelöst und für 5 min bei $1200 \mathrm{rpm}$ in einem 50-ml-Zentrifugenröhrchen zentrifugiert. Sie werden in frischem Medium resupendiert und die Suspension gut gemischt.

Zum Zählen der Zellen werden $10 \mu \mathrm{der}$ Suspension entnommen und in einem 1,5-mlReaktionsgefäß mit $40 \mu \mathrm{l}$ Trypan Blue gemischt. Je $10 \mu \mathrm{l}$ werden auf die beiden Seiten der vorbereiteten Neubauer Zählkammer gegeben. Am Mikroskop werden die 8 mal 16 Quadrate ausgezählt.

Zur Bestimmung der Zellzahl pro ml wird gezählte Zellzahl durch acht dividiert und dann mit fünf (Verdünnungsfaktor) und 10000 multipliziert:

Zellzahl / 8 = y x 5 x $10000=$ Zellzahl $/ \mathrm{ml}$.

Die errechnete Zellzahl pro ml wird nun durch die gewünschte Zellzahl pro ml geteilt. Das gewünschte Volumen wird durch den im vorigen Schritt errechneten Verdünnungsfaktor geteilt. Man erhält die Angabe des Volumens der Zellsuspension und zieht diese vom insgesamt gewünschten Volumen ab, um den Mediumanteil zu berechnen.

Die Suspension wird mit Hilfe der Auslaufpipetten in die Kavitäten bzw. Zellkulturflaschen gegeben.

\subsubsection{Primärkultur}

Zur Gewinnung von primären murinen Oligodendrozyten werden die Gehirne von neugeborenen Mäusen (C57B16; Tag 0-3) entnommen, mit einer Rasierklinge zerschnitten und in $23 \mathrm{ml}$ HBSS auf Eis gesammelt. Nach Zugabe von $1 \mathrm{ml}$ DNase und Papain wird die Suspension mit einer 1000- $\mu$ l-Eppendorf-Pipette luftblasenfrei trituiert und für $10 \mathrm{~min}$ bei 37 ${ }^{\circ} \mathrm{C}$ im Wasserbad inkubiert. Dann wird die Suspension zwei Mal mit einer 200- $\mu 1$-EppendorfPipette luftblasenfrei trituiert und wieder für $10 \mathrm{~min}$ im Wasserbad inkubiert.

Es werden $10 \mathrm{ml}$ Primärmedium dazugegeben und die Suspension durch ein $40-\mu \mathrm{m}-\mathrm{Netz}$ laufengelassen. Der Durchfluss wird für $7 \mathrm{~min}$ bei $2000 \mathrm{rpm}$ zentrifugiert und das entstehende Pellet in HBSS gelöst. Die Suspension wird auf vier Zentrifugenröhrchen mit je $35 \mathrm{ml}$ HBSS verteilt und für $7 \mathrm{~min}$ bei $1500 \mathrm{rpm}$ zentrifugiert. Das Pellet wird in $12 \mathrm{ml}$ Primärkulturmedium gelöst und verteilt. Hierbei lassen sich mit 5 Mäusehirnen acht Kavitäten einer 6er Platte füllen sowie mit einem Hirn 10 Kavitäten einer 24er Platte. 
Die Kavitäten sind vor dem Aussäen der Zellen für 1-2 Stunden mit PLL beschichtet, mit Wasser gespült und unter UV-Licht getrocknet worden.

Nach 24 Stunden wird das Medium abgesaugt und neues Primärkulturmedium zugegeben. Nach einer Woche werden die Zellen mit DMEM plus Additive zum Differenzieren versetzt und 48 Stunden später stimuliert.

\subsubsection{Stimulation der Zellen}

OLN-93-Zellen sind für die Versuche der vorliegenden Arbeit 24 Stunden nach dem Aussäen stimuliert worden; bei den CG-4-Zellen ist nach 24h erst ein Mediumwechsel zum Differenzieren der Zellen durchgeführt worden, nach weiteren 24h erfolgte die Stimulation mit dem jeweiligen Zelltodinduktor.

Folgende Konzentrationen von Zelltodinduktoren sind verwendet worden:

Staurosporin (Stimulation für 24h): Kontrolle; 10; 100; 250; $500 \mathrm{nM}$

SNAP (Stimulation für 48h): Kontrolle, $0.5 ; 1.0 ; 1.5 ; 2.0 ; 2.5 \mathrm{mM}$

ONOO $^{-}$(Stimulation für 24h): Kontrolle; 10; 100; 250; $500 \mu \mathrm{M}$

Mit jeder Konzentration wurden die CG-4- bzw. OLN-93-Zellen in 24er Kavitäten (für den MTT-Test) und in zwei Zellkulturflaschen $\left(75 \mathrm{~cm}^{2}\right.$ ) (eine Flasche für RNA-, eine für eine spätere Proteinextraktion) stimuliert.

Weitere Zelltodinduktoren:

TRAIL (Stimulation für 24, 48, 72h): Kontrolle; 100; $500 \mathrm{ng} / \mathrm{ml}$

Fas (Stimulation für 24h): Kontrolle; 0,1; 1; 10; $100 \mathrm{ng} / \mathrm{ml}$

(Stimulation für 48h): Kontrolle; 100; 500 bzw. $1000 \mathrm{ng} / \mathrm{ml}$

\subsubsection{Ernten der Zellen}

Zelltodinduktorabhängig sind die Zellen nach $24 \mathrm{~h}$ oder $48 \mathrm{~h}$ aus den Zellkulturflaschen geerntet worden.

Das Medium wird aus der Flasche entnommen und aufgehoben. Mit einem Zellschaber werden die Zellen sorgfältig vom Boden der Flasche gekratzt und die Flasche mit dem aufgehobenen Medium gespült. Die Suspension wird in ein 50-ml-Zentrifugenröhrchen übertragen und für $5 \mathrm{~min}$ bei $1200 \mathrm{rpm}$ zentrifugiert. Dann wird das Medium abgesaugt, die 
Zellen in $1 \mathrm{ml}$ PBS resuspendiert und in ein 1,5-ml-Reaktionsgefäß überführt. Sie werden als nächstes für 4 min bei $4{ }^{\circ} \mathrm{C}$ und $6000 \mathrm{rpm}$ zentrifugiert. Dann wird der Überstand abgesaugt und das Pellet sofort in flüssigem Stickstoff eingefroren und schließlich bei $-80{ }^{\circ} \mathrm{C}$ gelagert.

\subsection{MTT-Test}

Der MTT-Test misst die mitochondriale Respiration von lebenden Zellen und wird somit bei der Untersuchung von Zellproliferation sowie Zelltod eingesetzt.

Der Test beruht auf der Reduktion von Tetrazoliumsalzen (in diesem Fall 3- [4,5dimethylthiazol-2-yl]-2,5-diphenyltetrazolium-bromid) in den Mitochondrien lebender Zellen zu farbigen, wasserunlöslichen Formazansalzen. Bei dieser Reaktion wird NADH zu NAD ${ }^{+}$ oxidiert. Die entstehenden Salze werden gelöst und die Extinktion in einem ELISA-Reader gemessen. Die Farbentwicklung ist der Menge der lebenden Zellen proportional.

Durchführung:

1. Das MTT-Reagenz wird in der Konzentration $5 \mathrm{~g} / \mathrm{ml}$ in PBS gelöst. In dieser Form ist es lichtgeschützt bei $4{ }^{\circ} \mathrm{C}$ haltbar.

2. Zur Durchführung des Tests wird das gelöste MTT-Reagenz 1:10 mit Medium verdünnt. Das verbrauchte Medium wird von den Zellen abgesaugt und in jede Kavität der 24er Platte 0,5 ml des verdünnten MTT-Reagenz gegeben. Die Zellen werden für mindestens $30 \mathrm{~min}$, höchstens eine Stunde inkubiert, wobei mikroskopisch auf die Blaufärbung der Zellen sowie die Bildung von Kristallen geachtet wird. Nach dem Einsetzen der Kristallbildung wird die Inkubationsphase beendet.

3. Das Medium wird abgesaugt und die wasserunlöslichen Salze werden mit $250 \mu 1$ Isopropanol plus 37\% Salzsäure gelöst. Die Platte wird für 15 min auf den Schüttler gestellt (Geschwindigkeit 30).

4. Dann werden aus jedem Well zweimal je $100 \quad \mu l$ des Überstandes (Doppelbestimmung) in die 96-Kavitäten-Platte für den ELISA-Reader überführt.

5. Die Extinktion wird bei der Wellenlänge $540 \mathrm{~nm}$ (Referenzwellenlänge $655 \mathrm{~nm}$ ) gemessen.

\subsection{TUNEL-Färbung (TdT-mediated X-dUTP nick end labeling)}

Die TUNEL-Färbung ist eine Methode zur Bestimmung des Zelltods einzelner Zellen. Bei dieser Methode macht man sich die Tatsache zunutze, dass es während des Vorgangs der Apoptose einer Zelle zur DNA-Degradierung mit der Bildung von Fragmenten (Mono- und 
Oligonukleosomen) kommt. An die freien 3'-OH-Enden dieser Stücke werden durch eine Terminal-Desoxynukleotidyl-Transferase modifizierte Nukleotide angebaut. An die Nukleotide ist Digoxigenin gebunden, welches durch einen Antikörper (hier AntiDigoxigenin-Alkalische-Phosphatase) markiert wird. Die an den Antikörper gebundene Alkalische Phosphatase (AP) sorgt durch Umsatz ihres Substrates NBT/BCIP für die Farbentwicklung.

Um eine TUNEL-Färbung durchführen zu können, werden die Zellen auf Deckgläschen in den Kavitäten einer 24er Platte ausgesät. Nach Ende der Inkubationszeit mit dem jeweiligen Zelltodinduktor werden die Zellen nach Absaugen des Mediums für 25 min mit 4\%igem PFA fixiert und danach dreimal mit PBS gewaschen. Mit PBS versetzt sind sie so bei $4{ }^{\circ} \mathrm{C}$ haltbar.

TUNEL Mix (1x):

$14 \mu 1$ Tailing Puffer

$2,8 \mu \mathrm{l} \mathrm{CoCl}_{2}$

$0,7 \mu 1$ DIG-DNA

$0,35 \mu 1$ terminale Transferase

$52,15 \mu 1$ Aqua bidest.

Für die Färbung werden die Deckgläschen aus den Kavitäten entnommen, in eine 4er Gewebekulturschale überführt und viermal mit TBS-Puffer gespült. Auf jedes Deckgläschen werden $70 \mu \mathrm{l}$ des TUNEL-Mixes aufgetragen und diese für eine Stunde bei $37^{\circ} \mathrm{C}$ inkubiert. Dann werden die Deckgläschen fünfmal mit TBS-Puffer gespült.

Anti-Digoxigenin-Alkalische Phosphatase wird 1:1000 verdünnt und $50 \mu \mathrm{l}$ auf jedes Deckgläschen pipettiert. Die Inkubationszeit beträgt eine Stunde bei Raumtemperatur. Nach dreimaligem Spülen mit TBS-Puffer wird die Färbung mit NBT/BCIP Lösung entwickelt. Zur Gegenfärbung werden die Deckgläschen 10 min mit Kernechtrot versetzt.

Zur Fixierung auf einem Objektträger wird Aquamount verwendet.

\subsection{Nukleosomen-ELISA (Enzyme-linked Immunosorbent-Assay)}

Zur Untersuchung der Zellen auf Zelltod wurde in den Versuchen dieser Arbeit ein Nukleosomen-ELISA durchgeführt. Für diesen ELISA wurde der „Cell Death Detection ELISA“ Kit von Roche verwendet. Von der Art her handelt es sich bei dem durchgeführten ELISA um die Messung von Antigenen nach dem sogenannten „Sandwich Prinzip“. Hierbei ist nicht das Antigen, sondern der verwendete Antikörper enzymmarkiert. 
Im ersten Schritt des ELISA binden die Antigene (in diesem Fall Nukleosomen) aus den lysierten Zellen an den im Überschuss am Boden der ELISA-Platte fixierten Antikörper. In der zweiten Immunreaktion bindet ein weiterer enzymmarkierter Antikörper an eine andere Bindungsstelle des Antigens und es entsteht der Sandwichkomplex. Als Enzym wird zumeist eine aus Meerrettich gewonnene Peroxidase (POD) verwendet, welche im letzten Schritt nach Zugabe von Substrat und dem Chromogen ABTS für die Farbentwicklung sorgt, welche mit Hilfe eines ELISA-Readers gemessen wird. Zwischen der Farbintensität und der Antigenkonzentration der Probe besteht eine proportionale Beziehung.

Durchführung:

1. Aus den Kavitäten wird das Medium abgesaugt und die Zellen mit $150 \mu 1$ Lysispuffer/Kavität für 30 min bei Raumtemperatur lysiert.

2. Das Lysat wird in 1,5-ml-Reaktionsgefäße überführt und für $10 \mathrm{~min}$ bei 10000 Umdrehungen zentrifugiert.

3. Jeweils $20 \mu \mathrm{l}$ des Überstands werden in die Kavitäten der ELISA-Platte überführt. Dazu kommen für die Positiv- sowie für die Negativkontrolle je zwei Kavitäten.

4. In jede Kavität werden $80 \mu \mathrm{l}$ des Immunomix gegeben.

Einfacher Ansatz der Reaktionslösung:

- $72 \mu$ Inkubationspuffer

- $\quad 4 \mu$ Anti-Histon-Biotib Antikörper

- $4 \mu$ Anti-DNA-POD Antikörper

5. Die Platte wird mit Folie bedeckt und zwei Stunden bei Raumtemperatur geschüttelt.

6. Die Reaktionslösung wird aus den Kavitäten entfernt und diese dreimal mit 250 $\mu 1 /$ Kavität Inkubationspuffer gewaschen und danach jeweils ausgeschüttelt.

7. In jede Kavität wird $100 \mu \mathrm{l}$ der ABTS-Lösung pipettiert. Die Farbentwicklung wird bei der Wellenlänge $405 \mathrm{~nm}$ mit Referenzwellenlänge $490 \mathrm{~nm}$ im ELISA Reader gemessen. Die Messung erfolgt alle 5 min für einen Zeitraum von 20-30 min.

\subsection{RNA-Extraktion aus Zellpellets}

Die RNA-Extraktion aus den eingefrorenen Zellpellets erfolgte mit dem „RNeasy Mini“ Kit von Qiagen. Im Kit sind neben den Säulen, auf die die RNA gebunden wird, und den Sammel- und Elutionsgefäßen drei verschiedene Puffer (RLT, RW1 und RPE) sowie RNasefreies Wasser enthalten.

Durchführung: 
1. Zunächst wird RLT- $\beta$-Mercaptoethanol vorbereitet. Pro Probe werden $600 \mu$ RLT- $\beta$ Mercaptoethanol benötigt. $\mathrm{Zu}$ jedem ml später verwendetem RLT werden unter dem Abzug $10 \mu 1 \beta$-Mercaptoethanol gegeben.

2. Die Proben werden in $600 \mu 1$ RLT- $\beta$-Mercaptoethanol gelöst, gut gevortext und mit Hilfe einer Insulin-Spritze durch mehrmaliges Aufziehen lysiert.

3. Die Suspension wird mit $600 \mu 170 \%$ igem Ethanol versetzt, gemischt und zweimal je $600 \mu 1$ Lysat auf der im Kit enthaltenen Säule durch Zentrifugieren (30 s bei 12000 rpm) gebunden. Der Durchfluss wird jeweils verworfen.

4. Die Säulen werden mit $700 \mu \mathrm{RW} 1$ gewaschen und zentrifugiert (30 s bei 12000 rpm).

5. Die Säulen werden in ein neues Sammelröhrchen überführt und mit $500 \mu \mathrm{RPE}$ gewaschen. Nach dem Zentrifugieren (30 s bei 12000 rpm) wird der Durchfluss verworfen.

6. Die Säulen werden ein zweites Mal mit $500 \mu \mathrm{l}$ RPE gewaschen und zwei Minuten bei $13200 \mathrm{rpm}$ zentrifugiert.

7. Die Säule wird in ein neues Reaktionsgefäß überführt und für eine Minute bei 13200 rpm trocken zentrifugiert.

8. Die Säulen werden in die Elutionsgefäße gesetzt und die RNA mit $30 \mu \mathrm{l}$ RNAsefreiem Wasser (aus dem Kit) eluiert. Zentrifugieren bei $12000 \mathrm{rpm}$ für eine Minute.

9. Nach Bestimmung von Quantität und Qualität wird die RNA bei $-80{ }^{\circ} \mathrm{C}$ gelagert.

\subsection{Synthese der cDNA}

Da mit Hilfe der PCR nur DNA amplifiziert werden kann, muss RNA vorher durch reverse Transkription mit einer RNA-abhängigen DNA-Polymerase in cDNA umgeschrieben werden. Zur Denaturierung der RNA werden zu RNase-freiem Wasser 500 ng RNA zugegeben (insgesamt $12 \mu \mathrm{l}$ ). Das Gefäß wird für 5 min bei $65^{\circ} \mathrm{C}$ inkubiert und anschließend sofort auf Eis gestellt. Der RNase-Inhibitor wird 1:4 mit kaltem RT-Puffer verdünnt.

Ansatz des Mastermix (insgesamt $8 \mu \mathrm{l}$ ):

- $\quad 2 \mu 1$ RT-Puffer

- $\quad 2 \mu \mathrm{ldNTP}-\mathrm{Mix}$

- $\quad 2 \mu 1$ Primer

- $\quad 1 \mu \mathrm{l}$ RNase-Inhibitor

- $\quad 1 \mu \mathrm{l}$ Reverse Transkriptase.

Nach Zugabe der vorbereiteten RNA Inkubation im Thermocycler für 60 min bei $37{ }^{\circ} \mathrm{C}$. 


\subsection{Polymerase-Ketten-Reaktion (Polymerase Chain Reaction; PCR)}

Die PCR ist ein Verfahren, das eine exponentielle Vervielfältigung eines bestimmten Bereiches eines DNA-Moleküls ermöglicht. Der zu amplifizierende Bereich wird durch zwei Primer festgelegt, von denen der eine identisch mit dem 5'-Ende, der andere komplementär zum 3'-Ende des Abschnitts gewählt wird. Von diesen Primern aus synthetisiert eine DNA Polymerase den jeweils komplementären DNA-Strang aus zugegebenen Nukleotiden. Für die PCR verwendet man eine thermostabile DNA-Polymerase, die sogenannte Taq-Polymerase, die aus Thermophilus aquaticus, einem in heißen Quellen lebenden Bakterium, gewonnen wird.

Im ersten Schritt der PCR werden die beiden Stränge des DNA-Moleküls bei $95{ }^{\circ} \mathrm{C}$ denaturiert und getrennt. Daraufhin wird die Temperatur auf die vom jeweiligen Primerpaar abhängige sogenannte annealing (Anlagerungs-) Temperatur abgesenkt. Bei dieser Temperatur lagern sich die Primer an ihre komplementären Sequenzen an. Nun beginnt die Synthesephase: Bei $72{ }^{\circ} \mathrm{C}$, dem Temperaturoptimum des Enzyms, verlängert die TaqPolymerase von den Primern aus in 5'-3'-Richtung die Stränge komplementär zum Matrizenstrang. Danach ist der erste Zyklus beendet und die Temperatur wird wieder auf 95 ${ }^{\circ} \mathrm{C}$ erhöht, um die Stränge zu trennen. Im folgenden Zyklus dienen nun auch die neu synthetisierten Stränge als Vorlage und es entstehen Stränge mit definierter Länge; ihr 5'Ende entspricht dem Primer, ihr 3'-Ende dem 5'-Ende des Matrizenstranges, welches ebenfalls durch einen Primer definiert ist. Es kommt also mit steigender Zyklenzahl zu einer exponentiellen Vermehrung der Stränge mit definierter Länge, während die Zahl der Stränge mit undefinierter Länge nur linear zunimmt und damit vernachlässigbar ist.

Die PCRs dieser Arbeit wurden mit 30 Zyklen durchgeführt.

Einfacher Ansatz für $15 \mu 1$ :

- $\quad 4 \mu \mathrm{l}$ Puffer

- $\quad 0,4 \mu 1 \mathrm{dNTPs}$

- $\quad 0,1 \mu 1 \mathrm{Taq}$

- $\quad 0,5 \mu 1$ Primer vorwärts

- $\quad 0,5 \mu 1$ Primer rückwärts

- $\quad 9,5 \mu 1$ Aqua pura.

Dazu werden $5 \mu \mathrm{l}$ cDNA bzw. Aqua pura für die Mastermix-Kontrolle gegeben. 


\subsection{Real Time PCR}

Die Methode der Real Time PCR erlaubt die Quantifizierung der PCR-Produkte bereits während der Zyklen und damit die quantitative Untersuchung des Expressionslevels von mRNA. Man nutzt bei dieser Form der PCR die Tatsache, dass es während der ersten Zyklen der PCR zu einer exponentiellen Zunahme des Produkts kommt, später dagegen zu linearem Wachstum bzw. zu keiner Zunahme mehr. Der Mastermix für die Real Time PCR enthält einen Farbstoff (hier SYBR green I), welcher unspezifisch in die doppelsträngige DNA eingebaut wird. Das PCR-Gerät misst die Zunahme des Fluoreszenzsignals nach Anregung des Farbstoffes mit Licht einer bestimmten Wellenlänge und gibt an, in welchem Zyklus das Signal sich deutlich vom Hintergrund abhebt und die festgesetzte Schwelle überschreitet. Je mehr PCR-Produkt vorhanden ist, desto eher wird die Schwelle erreicht.

Parallel zum zu bestimmenden Gen wird ein sogenanntes house keeping gene amplifiziert. Für die Versuche dieser Arbeit ist hARP verwendet worden. Dieses Gen verändert sich in seiner Expression unter verschiedenen Bedingungen nicht und die Werte für seine Schwellenüberschreitung dienen als Vergleich. Die Ergebnisse werden als $\mathrm{x}$-fache Veränderung der mRNA-Expression der Probe zur unbehandelten Kontrolle normalisiert zum house keeping gene dargestellt.

Nach Durchlauf der Zyklen wird eine Schmelzpunktbestimmung der PCR-Produkte durchgeführt. Sie dient der Untersuchung der Qualität der amplifizierten DNA.

Die Ansätze der Real Time PCR werden in lichtundurchlässige Reaktionsgefäße pipettiert, um den Farbstoff möglichst vor Lichteinwirkung zu schützen. Nach Befüllen der PCRReaktionsgefäße mit Ansatz und cDNA bzw. Aqua pura werden sie mit Folie verschlossen.

Einfacher Ansatz für $15 \mu l$ Ansatz:

$-10 \mu 1$ Mastermix

$-0,14 \mu$ Primer vorwärts

$-0,14 \mu 1$ Primer rückwärts

$-4,72 \mu 1$ Aqua pura.

Dazu werden $5 \mu \mathrm{l}$ cDNA bzw. Aqua pura für die Mastermix- Kontrolle gegeben. 


\subsection{Agarose-Gel-Elektrophorese}

Die PCR-Produkte werden durch Gelelektrophorese nachgewiesen. Als Trägermaterial wird Agarose verwendet, ein aus Algen gewonnenes lineares Polysaccharid, welches durch Erhitzen in Puffer gelöst wird und eine Art Netz ausbildet. Ein elektrisches Feld sorgt für die Auftrennung der PCR-Produkte nach ihrer Größe: kleine Moleküle wandern schneller durch die Maschen des Agarosenetzes zur Anode als größere.

Mit Hilfe von Ethidiumbromid, das mit der DNA interkaliert und bei Bestrahlung mit UVLicht fluoresziert, können die Produkte auf dem Gel sichtbar gemacht und ihre Größe durch Vergleich mit einem Größenmarker abgeschätzt werden.

Durchführung:

1. Für ein 2\%iges Agarose-Gel werden 2 g Agarose auf $100 \mathrm{ml}$ TBE Puffer abgewogen.

2. Agarose und Puffer werden in der Mikrowelle bei $800 \mathrm{~W}$ für 2-3min aufgekocht, bis die Agarose vollständig gelöst ist.

3. In die heiße Flüssigkeit werden $8 \mu$ Ethidiumbromid gegeben; nach ausreichender Durchmischung wird das Gel in die vorbereitete Flachbettkammer mit Kamm gegossen.

4. Sobald das Gel erstarrt ist, wird es in die Elektrophoresekammer gelegt, mit Puffer übergossen und der Kamm gezogen.

5. Die Taschen werden mit je $5 \mu 1$ PCR-Produkt bzw. $3 \mu 1$ des Größenmarkers gefüllt.

6. Die Laufzeit beträgt $30 \mathrm{~min}$ bei einer Spannung von $120 \mathrm{~V}$.

7. Nach Ende der Laufzeit werden die Banden mittels UV-Licht sichtbar gemacht und dokumentiert. 


\subsection{Medien und Puffer}

\subsubsection{Zellkulturmedien}

N1 Medium mit Biotin:

- $500 \mathrm{ml}$ DMEM

- $5 \mathrm{ml} \mathrm{N1}$ Medium

- $5 \mathrm{ml}$ Penicillin/Streptomycin

- $200 \mu 1$ Biotin.

CG-4 (undifferenziert):

- $\quad 70 \%$ N1 Medium mit Biotin

- $\quad 30 \%$ B104 Medium.

CG-4 (differenziert):

- N1 Medium mit Biotin

- $2 \%$ FCS.

\section{OLN-93:}

- $500 \mathrm{ml} \mathrm{DMEM}$

- $50 \mathrm{ml} \mathrm{FCS}$

- $5 \mathrm{ml}$ Penicillin/Streptomycin.

Primäre gemischte Gliazellkulturen der Maus (Primärkulturmedium):

- $500 \mathrm{ml}$ DMEM

- $50 \mathrm{ml} \mathrm{NHS}$

- $5 \mathrm{ml}$ Penicillin/Streptomycin.

Primäre gemischte Gliazellkulturen der Maus (Differenzierungsmedium):

- $\quad 94,5 \mathrm{ml}$ DMEM

- $1 \mathrm{ml}$ Additive1

- 1 ml N1 Medium

- $\quad 200 \mu \mathrm{l}$ Insulin $(2,5 \mathrm{mg} / \mathrm{ml})$

- $\quad 10 \mu \mathrm{T}$ T3-Hormon

- $1 \mathrm{ml} \mathrm{BSA} \mathrm{(10 \%} \mathrm{in} \mathrm{Hanks')}$ 
- $1 \mathrm{ml} \mathrm{Na-Pyruvat} \mathrm{(100mM)}$

- $1 \mathrm{ml}$ Penicillin/Streptomycin

- $100 \mu \mathrm{l} \mathrm{D}{ }^{+}$Galactose $(7,5 \mathrm{mg} / \mathrm{ml})$.

Additive1:

- $1 \mathrm{mg}$ DMPH4

- 100 mg Ascorbinsäure

- $5 \mathrm{mg}$ Glutathion

In $20 \mathrm{ml}$ Wasser lösen, $\mathrm{pH}$ auf 6 einstellen und durch einen 0,2- $\mu \mathrm{m}$-Filter filtrieren.

T3-Hormon:

$20 \mathrm{mg} \mathrm{T3}$ in $10 \mathrm{ml}$ 0,01 M NaOH lösen und durch 0,2 $\mu \mathrm{m}$-Filter filtrieren. 1:10 in Hanks plus $1 \%$ BSA verdünnen.

Insulin:

$25 \mathrm{mg}$ in $10 \mathrm{ml} \mathrm{H-CMF}$ geben, $\mathrm{pH}$ mit $\mathrm{HCl}$ ansäuern, bis Insulin in Lösung geht, dann durch $0,2-\mu \mathrm{m}$-Filter filtrieren.

\subsubsection{Puffer}

Puffer und weitere Ansätze für die TUNEL-Färbung:

TRIS-Stammlösung:

$-60,57 \mathrm{~g}$ TRIS

$-400 \mathrm{ml} 1 \mathrm{M} \mathrm{HCl}$

Auf pH 7,5 einstellen und auf $1000 \mathrm{ml}$ mit Aqua bidest auffüllen.

TBS:

$-950 \mathrm{ml}$ Aqua bidest

$-50 \mathrm{ml}$ TRIS-Stammlösung

$-8,766 \mathrm{~g} \mathrm{NaCl}$. 
NBT/BCIP Puffer:

$-12,144 \mathrm{~g}$ TRIS

- 5,844 g NaCl

- $10,165 \mathrm{~g} \mathrm{MgCl}_{2}$

Auf pH 9,5 einstellen und auf $1000 \mathrm{ml}$ mit Aqua bidest auffüllen.

NBT (4-nitro-blue tetrazolium chloride):

$100 \mathrm{mg} / \mathrm{ml}$ in $70 \%$ Dimethylformamid (in bidest).

BCIP (5-bromo-4-chloro-3-indolyl phosphate):

$50 \mathrm{mg} / \mathrm{ml}$ in $100 \%$ Dimethylformamid.

Ansatz des Farbsubstrates:

- $225 \mu 1 \mathrm{NBT}$

- $175 \mu 1$ BCIP

In $50 \mathrm{ml} \mathrm{NBT/BCIP} \mathrm{Puffer.}$

Ladepuffer für die Gelelektrophorese:

TBE:

- 108g TRIS-Base

- 55g Borsäure

- 40 ml EDTA pH 8

Ad 1 Liter.

EDTA pH 8:

- 18,61g $\mathrm{Na}_{2}$ EDTA x $2 \mathrm{H}_{2} \mathrm{O}$

- $20 \mathrm{ml}$ bidest

pH 8 ad $100 \mathrm{ml}$. 


\subsection{Primer}

$\underline{\text { hARP }}$ (Anlagerungstemperatur: 53-61 ${ }^{\circ} \mathrm{C} ; 109$ Basenpaare)

vorwärts: CGA-CCT-GGA-AGT-CCA-ACT-AC

rückwärts: ATC-TGC-TGC-ATC-TGC-TTG

$\underline{\mathrm{MBP}(\text { Ratte) }}$ (Anlagerungstemperatur $58,8{ }^{\circ} \mathrm{C} ; 150$ Basenpaare)

vorwärts: AAG-AAC-TAC-CCA-CTA-CGG-CTC-C

rückwärts: CTA-AAT-CTG-CTG-AGG-GAC-AGG-C

MBP (Maus) (Anlagerungstemperatur $55^{\circ} \mathrm{C} ; 123$ Basenpaare)

vorwärts: GTA-CAA-GGA-CTC-ACA-CAC-GAG-A

rückwärts: GTT-CGA-GGT-GTC-ACA-ATG-TTC-T

PLP (Anlagerungstemperatur: $52{ }^{\circ} \mathrm{C} ; 265$ Basenpaare)

vorwärts: CAA-GAC-CTC-TGC-CAG-TAT-AG

rückwärts: AGA-TCA-GAA-CTT-GGT-GCC-TC

$\underline{\text { MAG }}$ (Anlagerungstemperatur $54{ }^{\circ} \mathrm{C} ; 159$ Basenpaare)

vorwärts: ACC-GCC-TTC-AAC-CTG-TCT-GT

rückwärts: CTC-GTT-CAC-AGT-CAC-GTT-GC

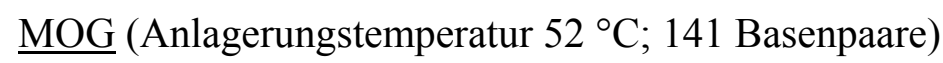

vorwärts: CCC-TTC-TAC-TGG-ATC-AAC-CCT-G

rückwärts: GAG-ATT-CTC-GAC-TTC-TGC-ACG-G

CNP (Anlagerungstemperatur $54{ }^{\circ} \mathrm{C} ; 246$ Basenpaare)

vorwärts: TGG-AGG-AGC-TGG-GAA-ATC-ACA-A

rückwärts: TCA-CAA-AGA-GGG-CAG-AGA-TGG-A

$\underline{\text { TRAIL-R2 }}$ (Anlagerungstemperatur für CG-4 Zellen 53,3 ${ }^{\circ} \mathrm{C}$, für OLN-93 Zellen $46,6{ }^{\circ} \mathrm{C}$; 220 Basenpaare)

vorwärts: CAA-AGG-CAA-ACC-GGA-AGT-GTG-T

rückwärts: GCG-TCC-AAG-AGA-GAT-AAA-CCC-A 


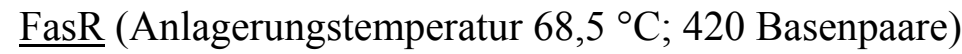
vorwärts: ACC-CGG-ACC-CAG-AAT-ACC-AAG-TGC rückwärts: GGG-GCT-GTT-GTG-CTC-GAT-CTC-ATC

\subsection{Materialien}

\section{Zellkultur Geräte und Verbrauchsmaterialien}

\begin{tabular}{|c|c|}
\hline Auslaufpipetten $(5 \mathrm{ml}, 10 \mathrm{ml}, 25 \mathrm{ml})$ & Sarstedt, Nümbrecht \\
\hline Reaktionsgefäße $(1,5 \mathrm{ml} ; 2 \mathrm{ml})$ & Sarstedt, Nümbrecht \\
\hline Falcons $(50 \mathrm{ml})$ & Sarstedt, Nümbrecht \\
\hline Gefrierschränke $\left(-20^{\circ} \mathrm{C} ;-80^{\circ} \mathrm{C}\right)$ & $\begin{array}{l}\text { Liebherr Comfort, Biberach an der Riss; } \\
\text { Sanyo, München }\end{array}$ \\
\hline Inkubatoren & $\begin{array}{l}\text { Hera Cell } 150 \text { Heraeus; } \\
\text { Cellstar Nunc GmbH Wiesbaden }\end{array}$ \\
\hline Kühlschränke $\left(4^{\circ} \mathrm{C}\right)$ & Liebherr Comfort, Biberach an der Riss \\
\hline $\begin{array}{l}\text { Mediumflaschen (Glas; verschiedene } \\
\text { Größen) }\end{array}$ & Schott Duran, St. Gallen, Schweiz \\
\hline Pasteurpipetten $250 \mathrm{ml}$ & WU, Mainz \\
\hline Pipettierhilfe „Accu-jet“ & Brand, Wertheim \\
\hline Wasserbäder & Köttermann, Uetze/Hänigsen \\
\hline 6, 24, 96 Kavitätenplatten („Wells“) & $\begin{array}{l}\text { Cellstar Greiner Bio-one } \mathrm{GmbH}, \\
\text { Frickenhausen }\end{array}$ \\
\hline Zählkammer nach Neubauer & „Assistent“ Karl Hecht, Sondheim/Rhön \\
\hline Zellkulturbank & $\begin{array}{l}\text { Microflow Medical Safety Cabinet, Andover, } \\
\text { Hants, UK }\end{array}$ \\
\hline Zellkulturflaschen „Cell Star“ $75 \mathrm{~cm} 2$ & Greiner Bio-one GmbH, Frickenhausen \\
\hline Zellschaber $(25 \mathrm{~cm})$ & Sarstedt, Nümbrecht \\
\hline Zentrifuge 5415R & Eppendorf, Hamburg \\
\hline
\end{tabular}




\section{Zellkultur Chemikalien}

\begin{tabular}{|c|c|}
\hline Ascorbinsäure & Sigma-Aldrich, Steinheim \\
\hline Biotase & Biochrom, Berlin \\
\hline Biotin & Sigma-Aldrich, Steinheim \\
\hline $\mathrm{BSA}$ & Serva, Heidelberg \\
\hline DNase & Roche, Mannheim \\
\hline $\begin{array}{l}\text { DMEM with Sodium Pyruvate, with L- } \\
\text { Glutamine; high Glucose }(4,5 \mathrm{~g} / \mathrm{l})\end{array}$ & PAA, Pasching, Österreich \\
\hline DMPH4 & Aldrich Chem., Milwaukee \\
\hline Fas Ligand & Alexis, Grünberg \\
\hline FCS & Biochrom, Berlin \\
\hline Galaktose (D+ Galaktose) & Sigma-Aldrich, Steinheim \\
\hline Glutathion & Sigma-Aldrich, Steinheim \\
\hline HBSS & PAA, Pasching, Österreich \\
\hline Insulin & Sigma-Aldrich, Steinheim \\
\hline $\mathrm{NaOH}$ & Merck, Darmstadt \\
\hline Natrium-Pyruvat & Gibco/Invitrogen, Karlsruhe \\
\hline NHS & Biochrom, Berlin \\
\hline N1-Medium & Sigma-Aldrich, Steinheim \\
\hline $\mathrm{ONOO}^{-}$ & $\begin{array}{l}\text { Calbiochem EMD Biosciences, Inc., San } \\
\text { Diego, USA }\end{array}$ \\
\hline Papain & Sigma-Aldrich, Steinheim \\
\hline PBS & Biochrom, Berlin \\
\hline Penicillin/Streptomycin & Biochrom, Berlin \\
\hline PLL & Biochrom, Berlin \\
\hline PLO & Sigma-Aldrich, Steinheim \\
\hline SNAP & Sigma-Aldrich, Steinheim \\
\hline Staurosporin & Sigma-Aldrich, Steinheim \\
\hline TRAIL Ligand & Biozol, Eching \\
\hline Trijodthyronin (T3) & Sigma-Aldrich, Steinheim \\
\hline TRIS & Sigma-Aldrich, Steinheim \\
\hline Trypan Blue & Sigma-Aldrich, Steinheim \\
\hline
\end{tabular}


Geräte und Chemikalien für Zellproliferation- und Zelltod-Tests

\begin{tabular}{|c|c|}
\hline BCIP & Roche, Mannheim \\
\hline Cell Death Detection ELISA Plus & Roche, Mannheim \\
\hline Dimethylformamid & Sigma-Aldrich, Steinheim \\
\hline Ethanol mit $\mathrm{HCl}$ & Merck, Darmstadt \\
\hline $\mathrm{HCl}(1 \mathrm{M})$ & Merck, Darmstadt \\
\hline $\mathrm{MgCl}_{2}$ & Sigma-Aldrich, Steinheim \\
\hline Microplate Reader Model 680 & BioRad, Hercules CA, USA \\
\hline MTT Reagenz & Sigma-Aldrich, Steinheim \\
\hline $\mathrm{NaCl}$ & Merck, Darmstadt \\
\hline NBT & Roche, Mannheim \\
\hline PFA & Merck, Darmstadt \\
\hline TRIS & Sigma-Aldrich, Steinheim \\
\hline
\end{tabular}

Verbrauchsmaterialien und Chemikalien für RNA-Extraktion

\begin{tabular}{|l|l|}
\hline$\beta$-Mercaptoethanol & Sigma-Aldrich, Steinheim \\
\hline Insulinspritzen & Braun, Melsungen \\
\hline Photometerküvetten & Sarstedt, Nümbrecht \\
\hline RNeasy Mini Kit & Qiagen, Hilden \\
\hline
\end{tabular}

\section{Geräte, Verbrauchsmaterialien und Chemikalien für PCRs}

\begin{tabular}{|l|l|}
\hline Agarose & Merck, Darmstadt \\
\hline Aqua pura & Roth, Karlsruhe \\
\hline PCR-Maschine & Biometra T3 Thermocycler, Göttingen \\
\hline Gelanalyse-System „Chemidoc“ & BioRad, München \\
\hline dNTPs & Roche, Mannheim \\
\hline
\end{tabular}


Material und Methoden

\begin{tabular}{|l|l|}
\hline Elektrophoresekammer SUB-CELL GT & BioRad, München \\
\hline Reaktionsgefäße (braun) & Sarstedt, Nümbrecht \\
\hline Ethidiumbromid & Roche, Mannheim \\
\hline Flachbettkammern & BioRad, München \\
\hline Folie & BioRad, München \\
\hline iCycler & BioRad, München \\
\hline Master Mix Real-Time-PCR & ABgene, Epsom, Surrey, UK \\
\hline PCR-Puffer & Promega, Madison, USA \\
\hline PCR-Reaktionsgefäße 8er Kette & Sarstedt, Nümbrecht \\
\hline Real-Time-PCR Reaktionsgefäße (96-Well & Sarstedt, Nümbrecht \\
Multiply-PCR Plate) & \\
\hline Pipetten Eppendorf Research (2,5 $\mu \mathrm{l} ; 20 \mu 1 ;$ & Eppendorf, Hamburg \\
$200 \mu 1 ; 1000 \mu l)$ & \\
\hline Pipettenspitzen & Sarstedt, Nümbrecht \\
\hline Netzgerät "Power Pac 300" & BioRad, München \\
\hline Primer & MWG, Ebersberg \\
\hline Taq-Polymerase & Promega, Madison, USA \\
\hline Waage & Sartorius analytic, Göttingen \\
\hline
\end{tabular}




\section{Ergebnisse}

Die Ergebnisse einer vorherigen Arbeit aus dem Institut für Neuropathologie der Universität Göttingen (Höff 2006) zeigen eine Heraufregulation der mRNA-Expression des Myelinproteins PLP in der oligodendroglialen Zelllinie OLN-93 unter dem Einfluss der schädigenden Substanzen SNAP und Peroxynitrit.

Dies korreliert mit dem Ergebnis von immunhistochemischen Färbungen von MS-Läsionen mit dem Demyelinisierungsmuster III. So findet sich in diesen Läsionen ein verstärktes Signal für PLP in den geschädigten, demyelinisierten Arealen im Vergleich zur normal erscheinenden angrenzenden weißen Substanz, während andere Myelinproteine wie z.B. CNP in der Läsion deutlich herunterreguliert sind (Abb. 1). OLN-93-Zellen, die mit SNAP oder Peroxynitrit behandelt werden, zeigen ein ähnliches Reaktionsmuster: Während die mRNASpiegel für PLP heraufreguliert werden, kommt es zu einer Herunterregulation von CNP.
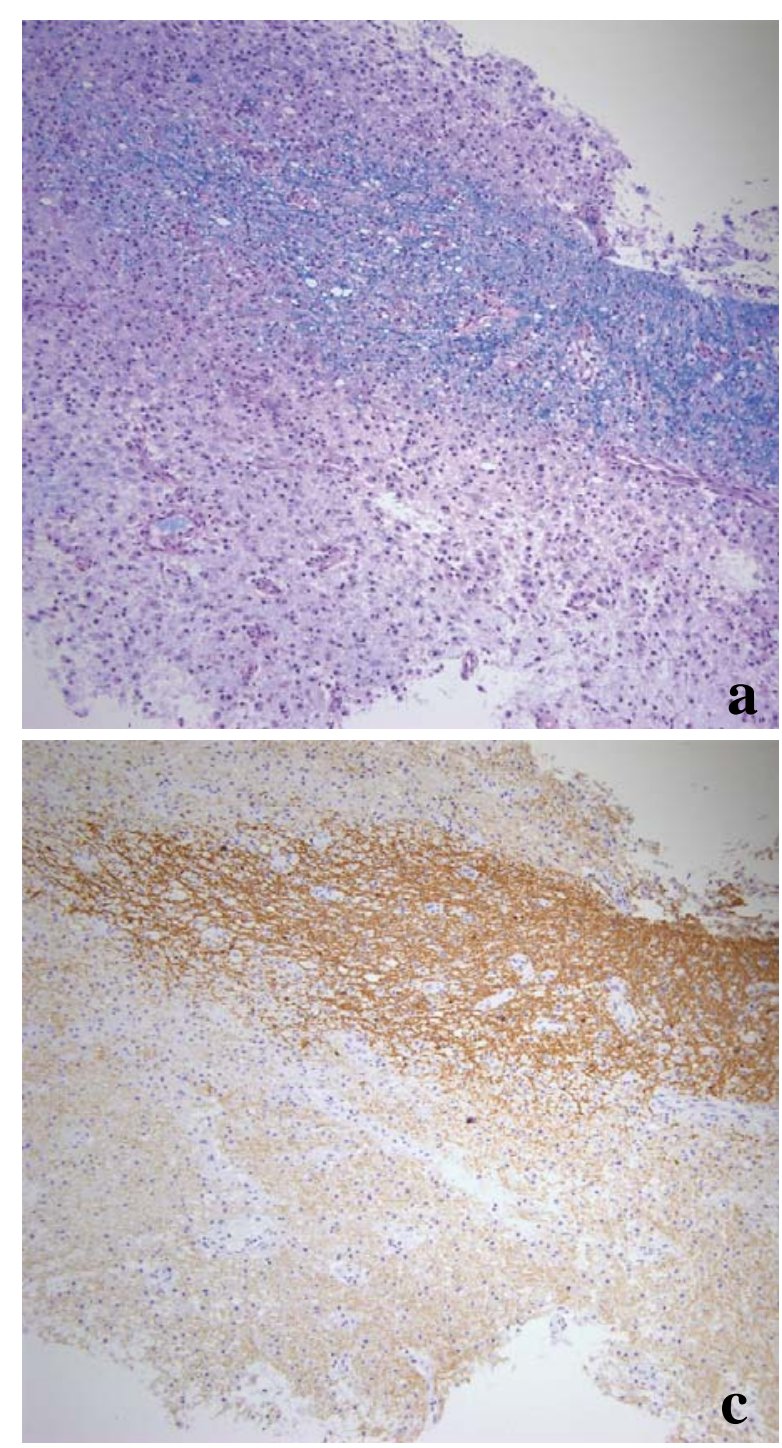

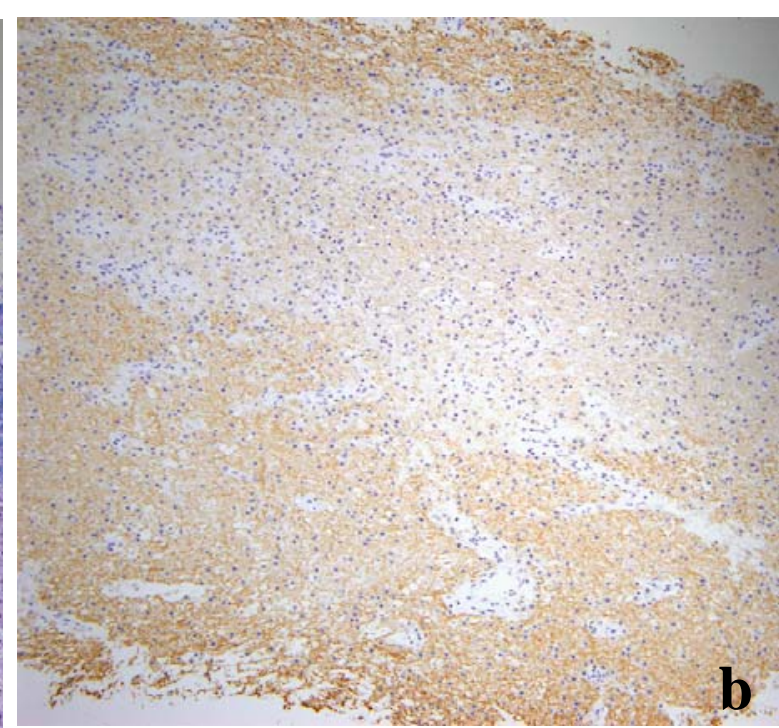

Abb. 1: Die LFB-PAS-Färbung (a) einer MS-Läsion vom Demyelinisierungsmuster Typ III zeigt das demyelinisierte Areal der Läsion mit normal erscheinender angrenzender weißer Substanz in der Mitte. Immunhistochemische Färbungen der gleichen Läsion zeigen ein erhöhtes Signal für PLP in der Läsion im Vergleich zur Umgebung (b), während das Signal für CNP in der normal erscheinenden weißen Substanz sich deutlich von dem der Läsion abhebt (c). 
Die Fragestellung dieser Arbeit begründet sich auf der Frage, ob das in OLN-93-Zellen beobachtete Phänomen der verstärkten Expression der PLP-mRNA für diese Zelllinie und die gewählten Zelltodinduktoren spezifisch ist oder ob es sich auch in anderen Zellpopulationen unter anderen schädigenden Einflüssen findet und somit weiterführend ein Zusammenhang zu dem charakteristischen Expressionsmuster der Myelinproteine in den MS-Läsionen zu untersuchen und zu diskutieren ist.

\subsection{Untersuchung des Effektes von Fas-Ligand, TRAIL, Staurosporin und Stickoxidmetaboliten auf die Zelllinien CG-4 und OLN-93 sowie PMGC- Zellen}

Vor diesem Hintergrund wurde zunächst der Einfluss der ausgewählten potentiell schädigenden Substanzen auf Zellen der beiden Zelllinien CG-4 und OLN-93 sowie auf murine primäre gemischte Gliazellkulturen (Primary mixed glial cultures; PMGC) untersucht. Der letale Effekt von Peroxynitrit und des Stickoxid-Donors SNAP auf die oligodendrogliale Zelllinie OLN-93 ist bereits bekannt (Jack et al. 2007). In der vorliegenden Arbeit wurde weiterführend der Einfluss von Staurosporin, einem Induktor des klassischen Apoptosewegs, sowie der beiden Mitglieder der TNF-Familie TRAIL und Fas untersucht.

\subsubsection{Fas}

Mittels PCR haben wir vor Beginn der Versuche nachgewiesen, dass die von uns verwendeten Zelllinien den Fas-Rezeptor exprimieren (Abbildung nicht gezeigt).

Um zu untersuchen, inwiefern FasL einen schädigenden Einfluss auf die beiden oligodendroglialen Zelllinien CG-4 und OLN-93 hat, wurden die Zellen für 24 und 48 Stunden verschiedenen Konzentrationen von FasL ausgesetzt. Dabei wurde das Experiment parallel an Zellen durchgeführt, deren Nährmedium zusätzlich $10 \mathrm{ng} / \mathrm{ml}$ Cycloheximid (CHX) enthielt. Hierbei handelt es sich um einen Inhibitor der Proteinsynthese, der in mehreren Studien eingesetzt wurde, um die Zellen anfälliger für die Wirkung der Liganden zu machen. Vor Stimulation der Zellen mit FasL wurden diese Zellen zwei Stunden in CHX-haltigem Medium vorinkubiert.

Nach Beendigung der Inkubationszeit wurde der MTT-Test durchgeführt. Die Diagramme zeigen die Ergebnisse des MTT-Tests nach 48 Stunden Inkubationszeit. Die Ergebnisse des 
MTT-Tests nach 24 Stunden zeigen keine Veränderung der mitochondrialen Respiration im Vergleich zur Kontrolle (Abbildungen nicht gezeigt).
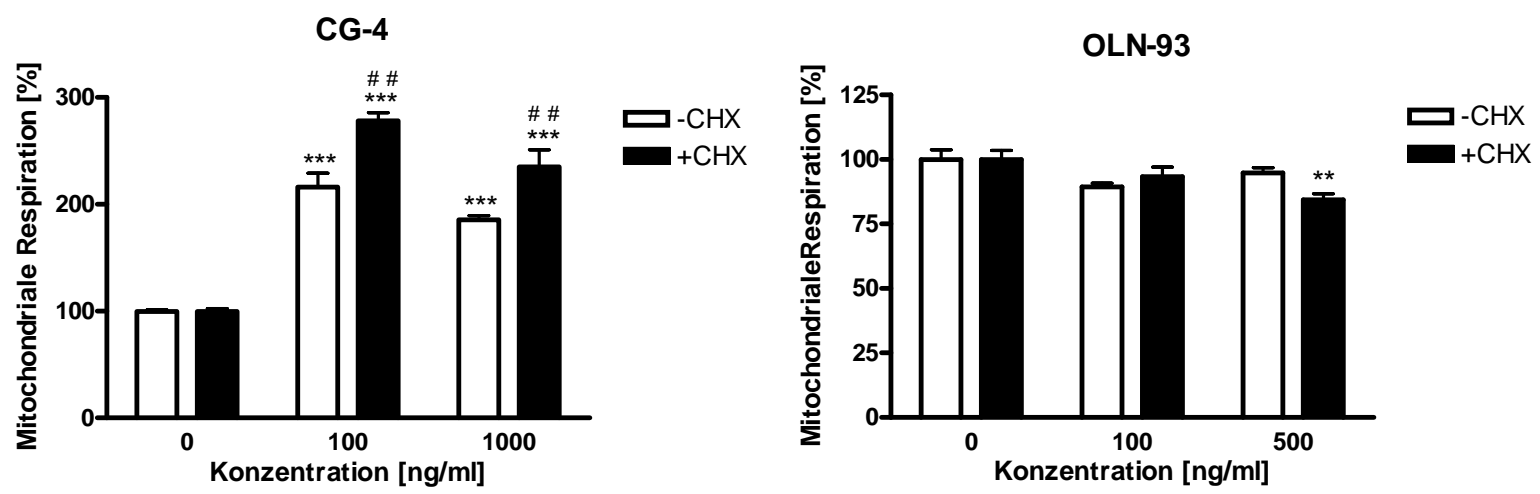

Abb. 2: Zu sehen sind die Ergebnisse der MTT-Tests von CG-4 und OLN-93 nach Inkubation mit Fas-Liganden für 48 Stunden. Es ist die Veränderung der mitochondrialen Respiration in Prozent im Vergleich zur unbehandelten Zellpopulation (100\% mitochondriale Respiration) in Abhängigkeit von der Konzentration von Fas-Ligand im Medium aufgetragen. Es zeigt sich außer bei OLN-93 nach Vorinkubation mit CHX und Inkubation mit der höchsten Konzentration Fas bei keiner der beiden Zellpopulationen eine signifikante Abnahme der mitochondrialen Respiration im Vergleich zur Kontrolle, sondern bei CG-4 sogar eine Zunahme. Auch die zusätzliche Behandlung mit CHX führt zu keiner deutlichen Abnahme im Vergleich zu den nur mit Fas-Ligand behandelten Zellen.

$* * \mathrm{P}<0,01 ; * * * \mathrm{P}<0,001$ im Vergleich zur jeweiligen Kontrolle.

\# \# P $<0,01$ im Vergleich zur nicht mit CHX vorbehandelten Kultur, die mit der gleichen Konzentration Fas versetzt wurde.

Die mitochondriale Respiration nimmt bei CG-4 nicht signifikant ab; auch nach Vorinkubation mit CHX bzw. Durchführung des Versuches mit CHX-haltigem Medium zeigen sich nur bei der höchsten Konzentration von FasL signifikante Unterschiede bei OLN93. Während die Zahl der Zellen mit intakter mitochondrialer Respiration sich im Versuch mit OLN-93 im Vergleich zur unbehandelten Kontrolle kaum verändert, zeigt sich nach Behandlung von CG-4 im Gegensatz dazu sogar eine Zunahme der mitochondrialen Respiration.

\subsubsection{TRAIL}

Vor Beginn der Versuchsreihe wiesen wir mit PCRs nach, dass die beiden Zelllinien den TRAIL-Rezeptor exprimieren (Abbildung nicht gezeigt).

Zellen der beiden Zelllinien CG-4 und OLN-93 wurden für 24, 48 und 72 Stunden mit TRAIL stimuliert, wobei ebenso wie bei FasL das Experiment parallel an Zellen durchgeführt wurde, deren Medium zusätzlich $10 \mathrm{ng} / \mathrm{ml} \mathrm{CHX} \mathrm{enthielt.} \mathrm{Bereits} \mathrm{zwei} \mathrm{Stunden} \mathrm{vor}$ 
Stimulation mit TRAIL wurde eine Vorinkubation mit dem CHX-haltigen Medium durchgeführt.

Gezeigt werden hier die Ergebnisse der Versuche mit einer Inkubationszeit von 48 Stunden (OLN-93) und 72 Stunden (CG-4). Nach den anderen ausgewählten Inkubationszeiten kam es im MTT-Test zu nur geringfügig von den gezeigten Werten abweichenden Raten für die mitochondriale Respiration (Abbildungen nicht gezeigt).

Die durchgeführten MTT-Tests zeigen eine Abnahme der mitochondrialen Respiration. Bei OLN-93 ist diese bei den nicht-vorinkubierten Zellen sowie bei der höchsten Konzentration TRAIL und Vorinkubation mit CHX signifikant im Vergleich zur Kontrolle.
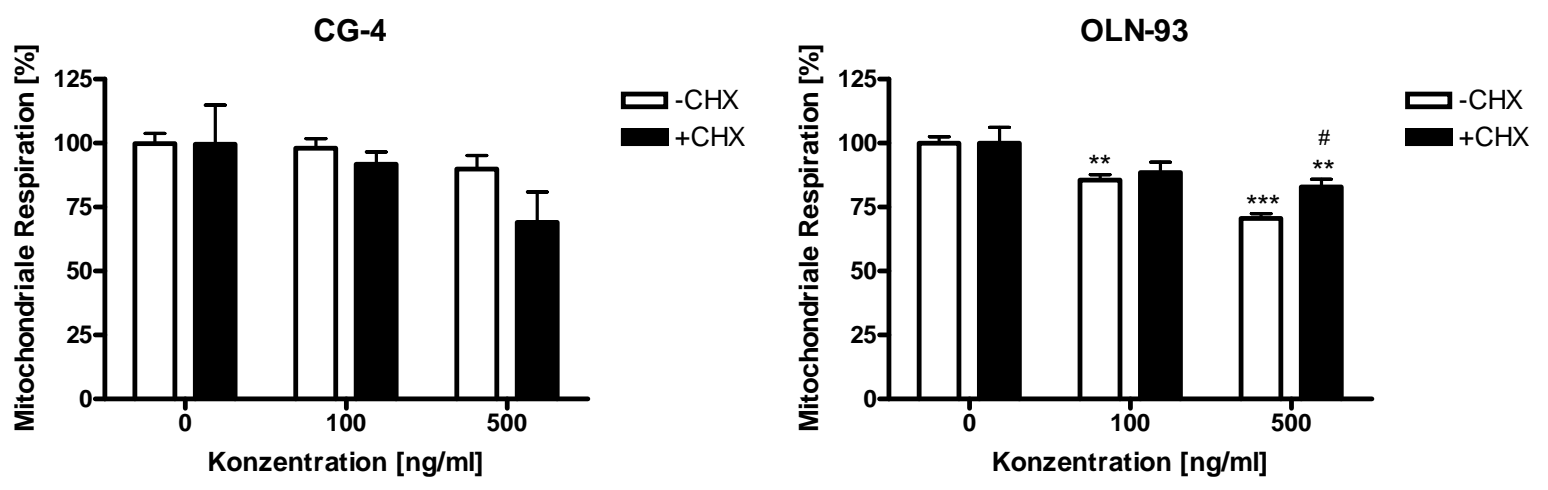

Abb. 3: Die Diagramme zeigen die Veränderung der mitochondrialen Respiration in Prozent im Vergleich zur unbehandelten Zellpopulation (100\% mitochondriale Respiration) in Abhängigkeit von der Konzentration von TRAIL im Medium. Nach 48 Stunden Inkubation mit TRAIL enthaltendem Medium finden sich signifikant weniger OLN-93-Zellen mit intakter mitochondrialer Respiration als in der unbehandelten Kontrolle. Dieser Effekt tritt ebenfalls nach Vorinkubation bzw. Versuchsdurchführung mit CHX-haltigem Medium bei OLN-93 auf. Bei CG-4 ist auch eine Abnahme erkennbar; diese ist aber nicht signifikant.

** $\mathrm{P}<0,01 ; * * * \mathrm{P}<0,001$ im Vergleich zur jeweiligen Kontrolle.

\# P $<0,05$ im Vergleich zur nicht mit CHX vorbehandelten Kultur, die mit der gleichen Konzentration TRAIL versetzt wurde.

Um zu untersuchen, ob die beobachtete Abnahme der mitochondrialen Respiration nach Inkubation mit TRAIL-haltigem Medium mit apoptotischen bzw. nekrotischen Zellen in Zusammenhang steht, wurde jeweils ein Nukleosomen-ELISA und die TUNEL-Färbung durchgeführt.

Der Nukleosomen-ELISA zeigt weder bei OLN-93-Zellen nach 48 Stunden noch bei CG-4Zellen nach 72 Stunden ein Verhältnis an apoptotischen Zellen, welches über das normalerweise in kultivierten oligodendroglialen Zellinien zu erwartende Maß hinausgeht. Die ermittelten Werte reichen nicht an die von der Positiv-Kontrolle erreichten Werte heran. 


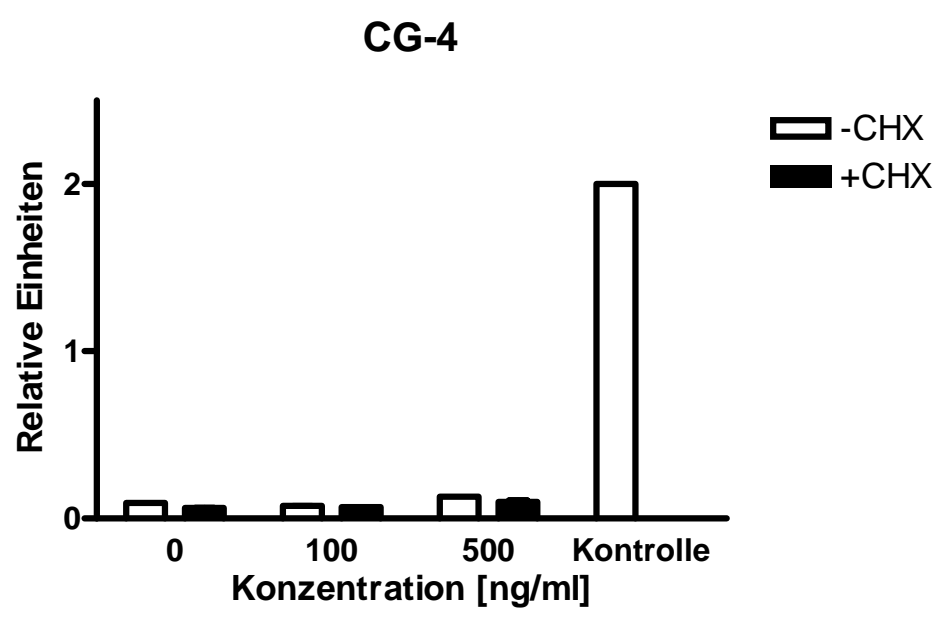

\section{OLN-93}

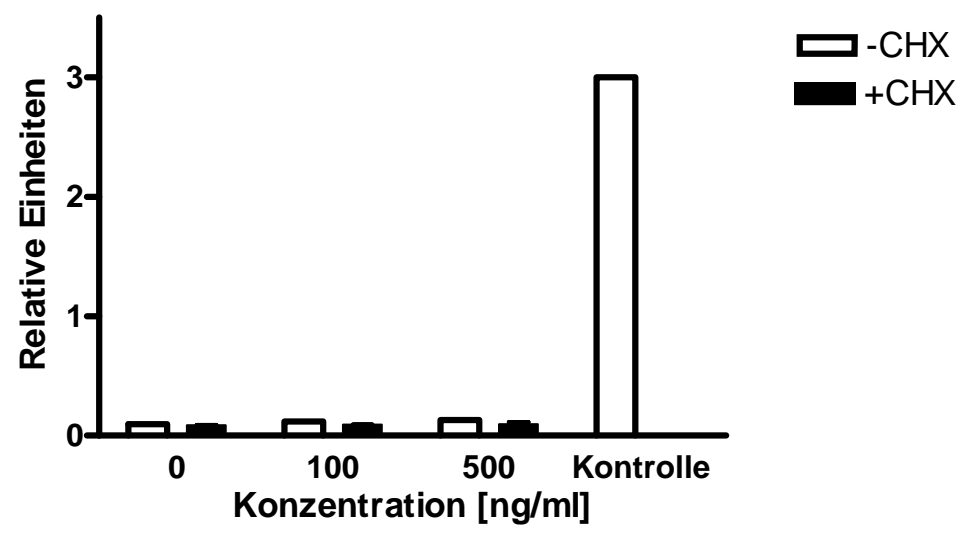

Abb. 4: Aufgetragen sind in den beiden Diagrammen jeweils die Ergebnisse der Messung im ELISA-Gerät in relativen Einheiten in Abhängigkeit zur Konzentration von TRAIL im Nährmedium. Für den ELISA wurde ebenfalls eine Zellpopulation zusätzlich zu den verschiedenen Konzentrationen TRAIL mit $10 \mathrm{ng} / \mathrm{ml}$ CHX behandelt. $\mathrm{Zu}$ sehen sind die Ergebnisse nach Behandlung von CG-4 für 72 Stunden und OLN-93 für 48 Stunden. Es zeigt sich in allen Zellgruppen keine Zunahme der Zelltodrate nach Behandlung mit TRAIL. Die Werte der Positivkontrollen (im Versuch mit OLN-93 „3“ (relative Einheit); im Versuch mit CG-4 „2“ (relative Einheit)) werden in keinem Experiment erreicht. 
Auch die TUNEL-Färbung zeigt keine apoptotischen Zellen. Hier werden nur die Ergebnisse für die höchste Konzentration TRAIL (500 ng/ml) ohne und mit CHX-haltigem Medium gezeigt, da sich nach Inkubation der Zellen mit den anderen Konzentrationen von TRAIL ohne und mit CHX-haltigem Medium in der TUNEL-Färbung dasselbe Bild zeigte.

Im Vergleich zur Kontrolle sind die Zellen ebenso dicht gewachsen und zeigen keine sichtbaren morphologischen Unterschiede.
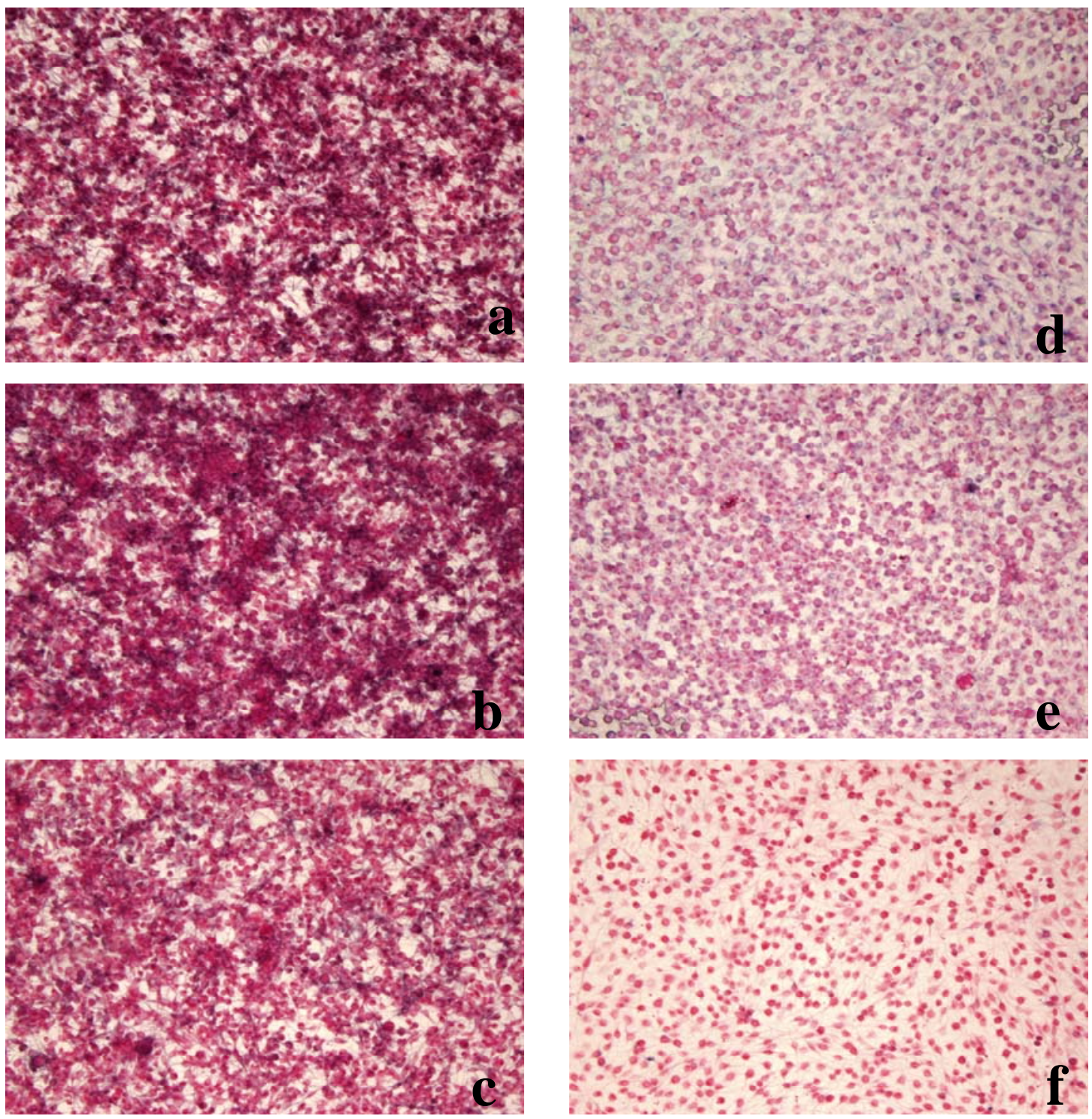

Abb. 5: Die Bilder a, b und c zeigen die TUNEL-Färbung von CG-4-Zellen. In (a) sind die unbehandelten Kontrollzellen zu sehen; (b) und (c) zeigen die Zellen nach Behandlung mit $500 \mathrm{ng} / \mathrm{ml}$ TRAIL, bei (c) in CHX-haltigem Medium. Es finden sich in (b) und (c) keine TUNEL-positiven apoptotischen Zellen. Außerdem ergeben sich keine deutlichen Veränderungen in Zellzahl und Morphologie.

Die Bilder (d), (e) und (f) zeigen die entsprechenden Experimente mit OLN-93-Zellen. Abb. 5d zeigt die Kontrollzellen. Nach Stimulation mit der höchsten Konzentration TRAIL in (e) und (f) sind auch hier keine TUNEL-positiven Zellen zu sehen. Unter Zugabe von CHX zeigt sich in (f) eine Reduktion der Zellzahl. 


\subsubsection{Staurosporin}

Mit Hilfe des MTT-Tests wurde die Wirkung von Staurosporin auf die beiden Zelllinien sowie die Primärkulturzellen untersucht. Der Test ist nach 24 Stunden Inkubationszeit gemacht worden. Hier zeigt sich bei allen drei Zellpopulationen eine sehr deutliche, z.T. fast lineare signifikante Abnahme der mitochondrialen Respiration mit steigenden Konzentrationen Staurosporin. Nach Behandlung der Zellen mit der höchsten Konzentration sinkt die mitochondriale Respiration auf Werte unter 50\%; bei CG-4-Zellen sogar auf unter 10\%. Bereits lichtmikroskopisch zeigte sich hier eine deutliche Schädigung der Zellen. Sie waren morphologisch verändert und kaum noch auf dem Boden der Zellkulturflasche fixiert.

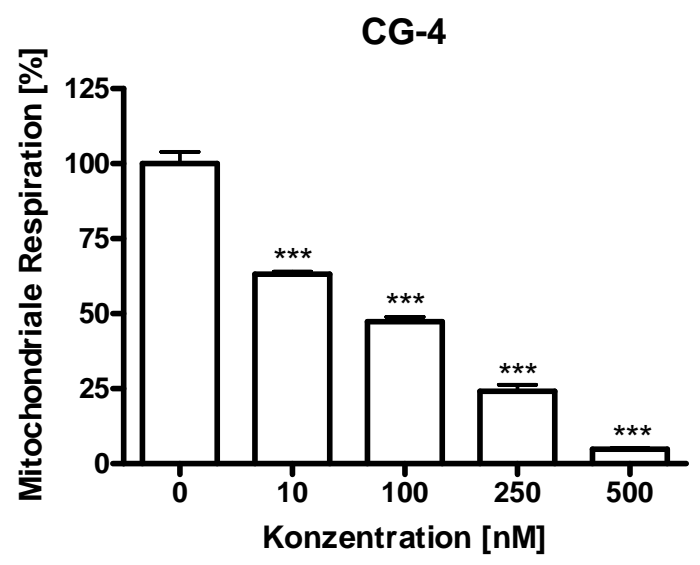

Abb. 6: Die Diagramme zeigen den Verlauf der mitochondrialen Respiration in Prozent bei den drei mit Staurosporin behandelten Zellpopulationen in Abhängigkeit von der Konzentration. $\mathrm{Zu}$ sehen ist die signifikante Abnahme der mitochondrialen Respiration bei CG-4, OLN-93 und PMGC nach 24-stündiger Behandlung bei z.T. bereits niedrigen Konzentrationen Staurosporin. $* * \mathrm{P}<0,01 ; * * * \mathrm{P}<0,001$ im Vergleich zur unbehandelten Kontrolle.
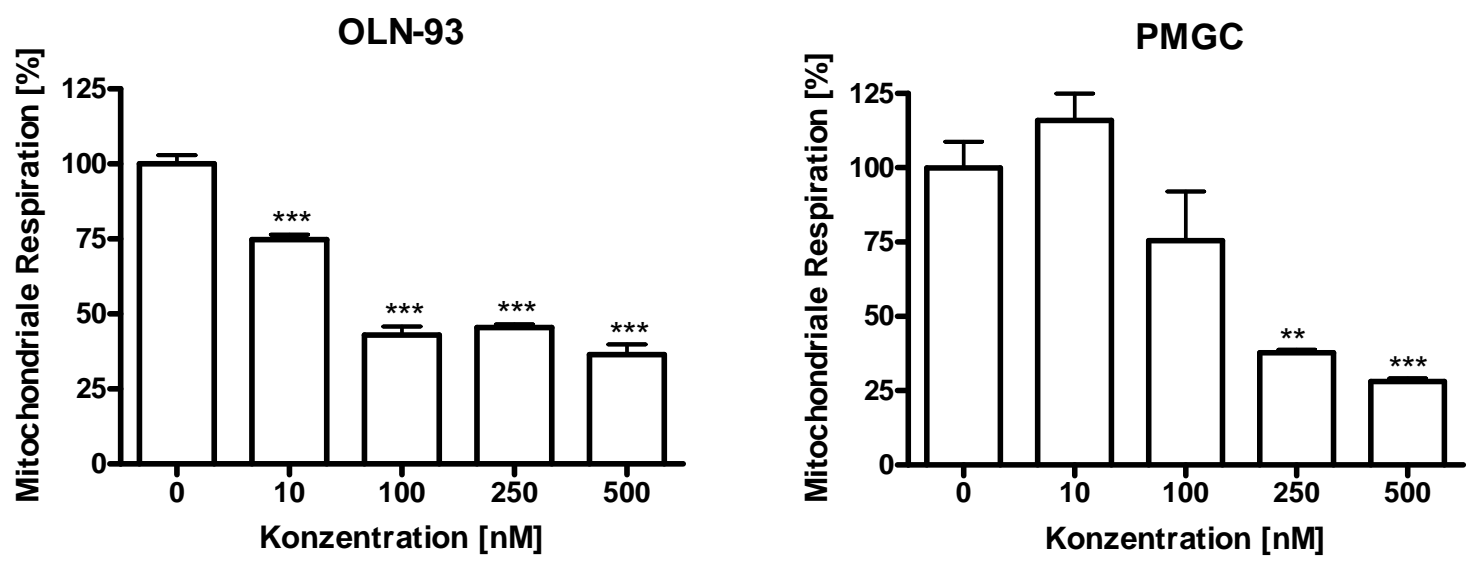
Ergänzend wurde eine TUNEL-Färbung durchgeführt, um apoptotische Zellen nachweisen zu können.

Exemplarisch werden hier die Bilder der TUNEL-Färbung von CG-4-Zellen gezeigt, welche für 24 Stunden mit $5 \mathrm{nM}$ Staurosporin behandelt wurden. Deutlich $\mathrm{zu}$ sehen sind die charakteristisch gefärbten schwarzen TUNEL-positiven Zellen (Pfeile).
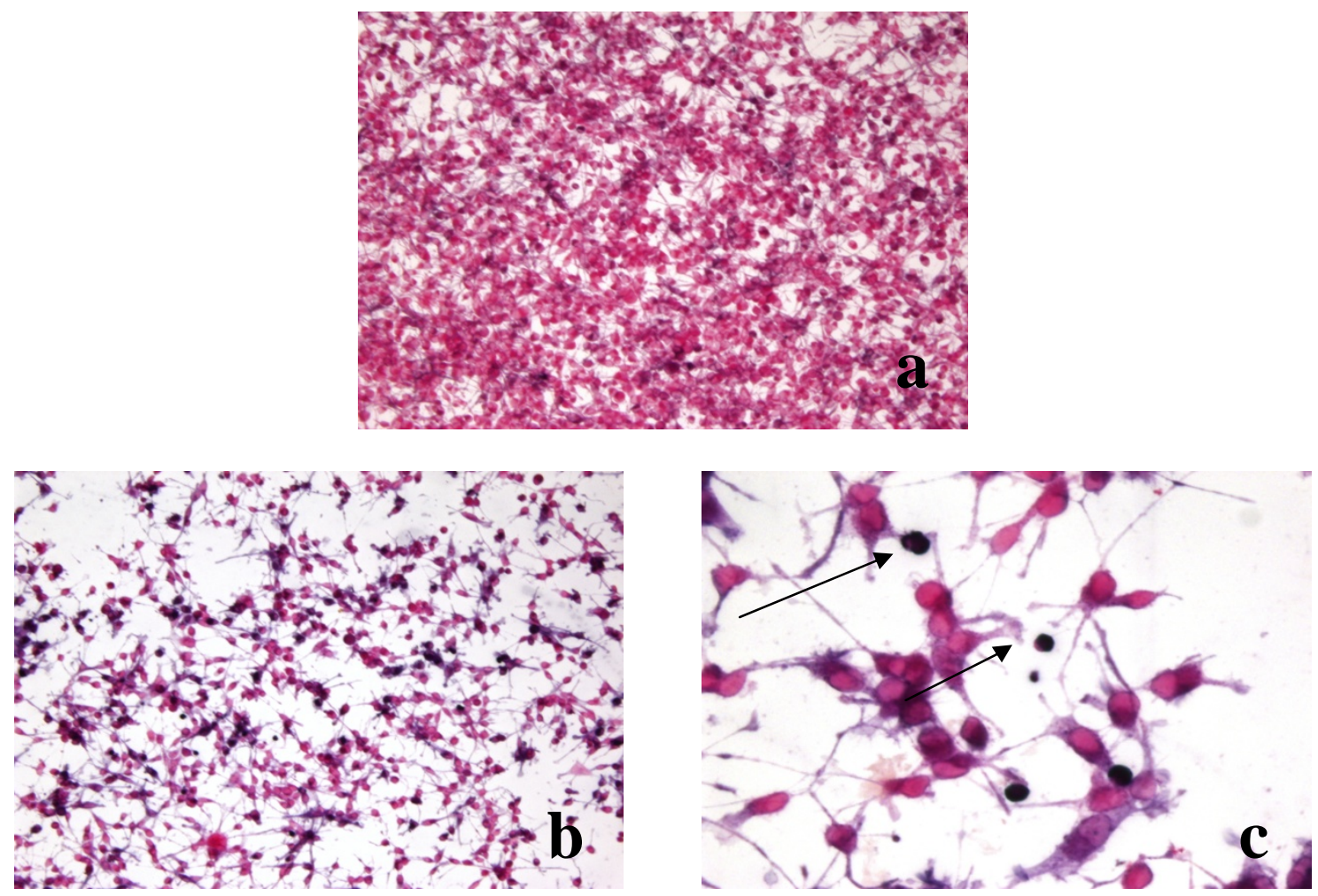

Abb. 7: Bild (a) zeigt unbehandelte CG-4-Zellen, die zur Kontrolle gefärbt wurden. In (b) und (c) sind CG-4Zellen nach 24 Stunden Behandlung mit $5 \mathrm{ng} / \mathrm{ml}$ Staurosporin zu sehen. Es findet sich eine deutliche Abnahme der Zellzahl und bereits in der schwächsten Vergrößerung (b) fallen die zahlreichen dunklen Zellen auf, welche sich in stärkerer Vergrößerung (c) deutlich als TUNEL-positive apoptotische Zellen darstellen (Pfeile). 


\subsubsection{SNAP}

Mit den folgenden Versuchen konnten wir zeigen, dass neben Staurosporin auch SNAP Zelltod in unseren Zellpopulationen auslöst.
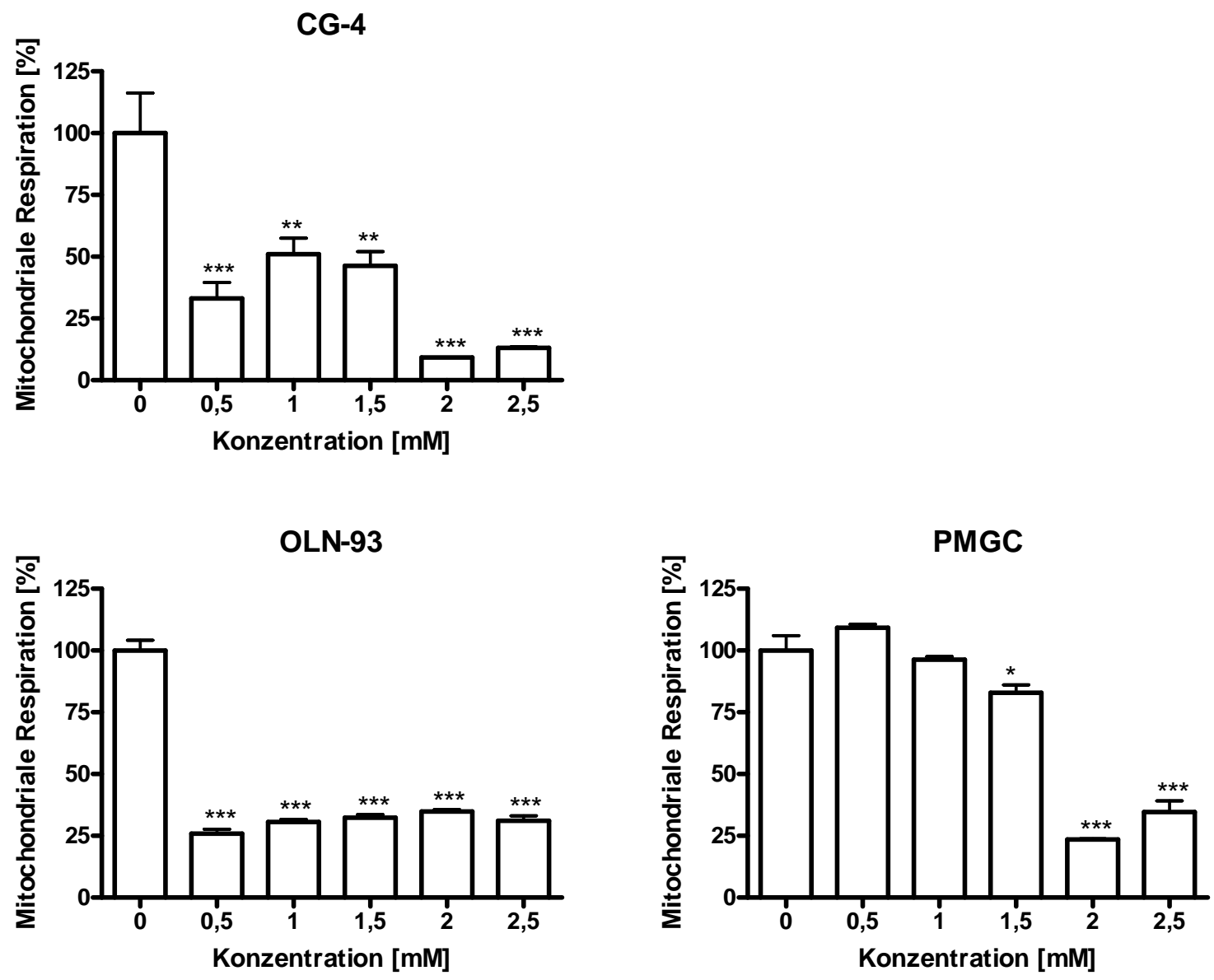

Abb. 8: Die Diagramme zeigen die Ergebnisse des MTT-Tests nach Inkubation der beiden Zelllinien CG-4 und OLN-93 sowie primärer gemischter Gliazellkulturen (PMGC) mit SNAP für 48 Stunden. Es ist die Veränderung der mitochondrialen Respiration in Prozent im Vergleich zur unbehandelten Zellpopulation (100\% mitochondriale Respiration) in Abhängigkeit von der Konzentration von SNAP im Medium aufgetragen. Man erkennt in allen drei Diagrammen eine signifikante Abnahme des Anteils von Zellen mit intakter mitochondrialer Respiration. Die Ergebnisse der Inkubation von OLN-93 mit SNAP basieren auf Versuchen, welche im Rahmen einer vorhergegangenen Arbeit durchgeführt worden sind (Höff 2006).

$* \mathrm{P}<0,05 ; * * \mathrm{P}<0,01 ; * * * \mathrm{P}<0,001$ im Vergleich zur unbehandelten Kontrolle. 


\subsubsection{Peroxynitrit}

Nach Stimulation mit Peroxynitrit kommt es bei höheren Konzentrationen zu einer signifikanten Abnahme von CG-4- und OLN-93-Zellen mit intakter mitochondrialer Respiration. PMGC-Zellen zeigen keine signifikante Veränderung.
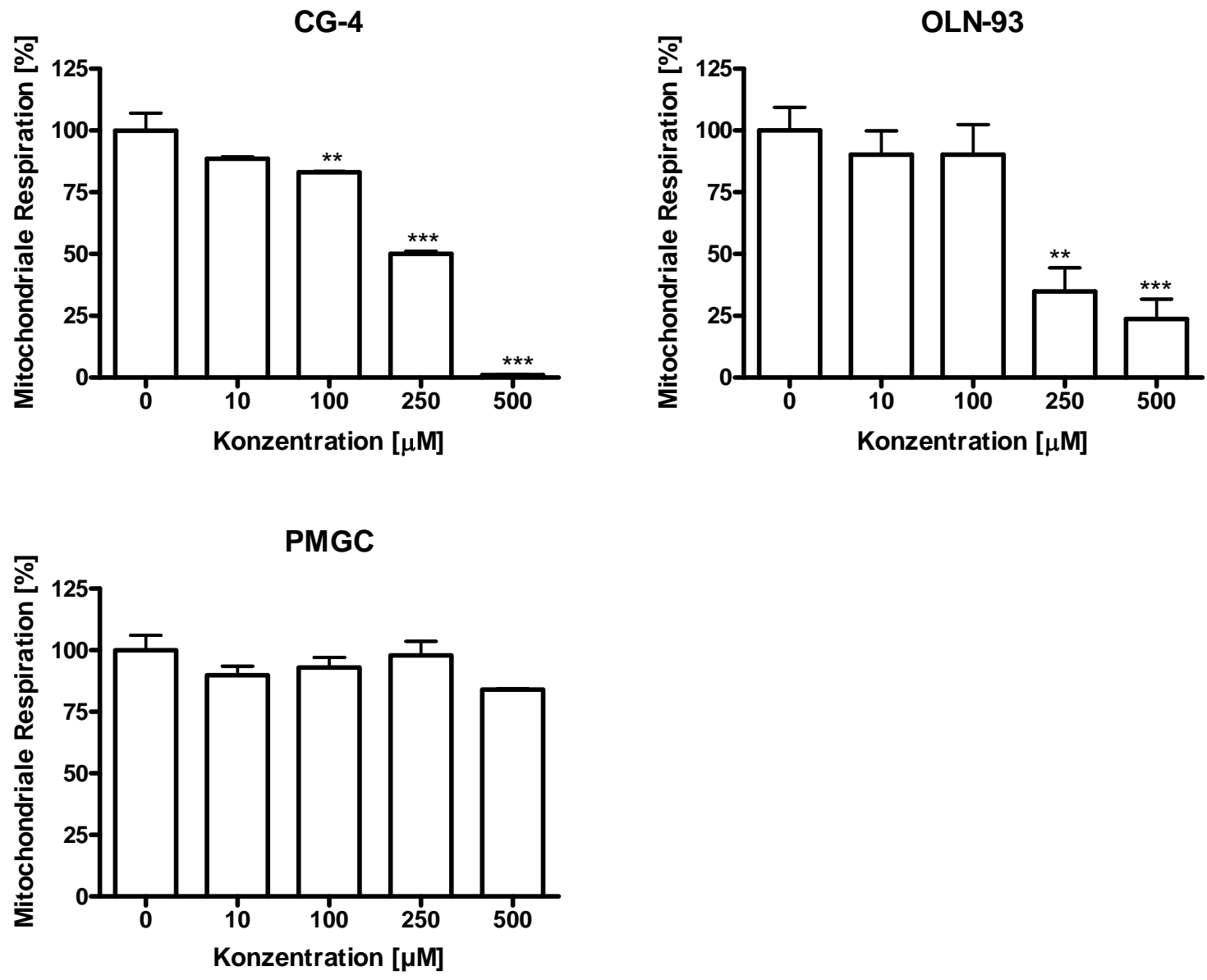

Abb. 9: Dargestellt sind die Ergebnisse des MTT-Tests von CG-4, OLN-93 und primären gemischten Gliazellkulturen (PMGC) nach Inkubation mit Peroxynitrit für 24h. Es ist die Veränderung der mitochondrialen Respiration in Prozent im Vergleich zur unbehandelten Zellpopulation (100\% mitochondriale Respiration) in Abhängigkeit von der Konzentration von Peroxynitrit im Medium aufgetragen. Die Inkubation der Zelllinien CG-4 und OLN-93 mit Peroxynitrit für 24 Stunden führt im MTT-Test zu einer signifikanten Abnahme der Zellen mit intakter mitochondrialen Respiration. PMGC-Zellen zeigen keine signifikante Abnahme. Die Ergebnisse der Inkubation von OLN-93 mit Peroxynitrit basieren auf Versuchen, welche im Rahmen einer vorhergehenden Arbeit durchgeführt worden sind (Höff 2006).

$* * \mathrm{P}<0,01 ; * * * \mathrm{P}<0,001$ im Vergleich zur unbehandelten Kontrolle. 
Nachdem die vorgestellten Ergebnisse zeigen, dass sowohl Fas-Ligand als auch TRAIL in den beiden Zelllinien keinen Zelltod auslösen, wurden für den zweiten Teil der Arbeit die Zelltodinduktoren SNAP, Peroxynitrit und Staurosporin gewählt.

Dieser Teil der Arbeit beschäftigt sich mit der Frage, inwiefern die ausgewählten Zelltodinduktoren zu einer Veränderung der mRNA-Expression der Myelinproteingene in den beiden Zelllinien und in PMGC-Zellen führen.

\subsection{Analyse der Expression verschiedener Myelingene in unbehandelten}

\section{CG-4-, OLN-93- und primären glialen Zellkulturen}

In einem den quantitativen Real Time PCRs vorangehenden Experiment wurde zunächst mit Hilfe von PCRs untersucht, welche der ausgewählten Myelinproteingene in den unbehandelten Zellen exprimiert werden. OLN-93-Zellen exprimieren nur PLP und CNP, während CG-4-Zellen und PMGC neben diesen beiden außerdem MBP und MAG exprimieren. Wir haben in keiner der drei Zellpopulationen eine Expression von MOG gefunden. Die Ergebnisse sind in nachfolgender Tabelle zusammengefasst.

\begin{tabular}{|l|c|c|c|}
\hline & CG-4 & OLN-93 & PMGC \\
\hline PLP & + & + & + \\
\hline CNP & + & + & + \\
\hline MBP & + & - & + \\
\hline MAG & + & - & + \\
\hline MOG & - & - & - \\
\hline
\end{tabular}

Tabelle 1: Mittels PCR ist die Expression der Myelinproteingene PLP, CNP, MBP, MAG und MOG in den beiden Zellinien CG-4 und OLN-93 sowie in PMGC-Zellen untersucht worden. Es zeigt sich, dass CG-4 und PMGC-Zellen alle ausgewählten Gene bis auf MOG exprimieren, während OLN-93-Zellen nur PLP und CNP exprimieren. 


\subsection{Effekte von Staurosporin, SNAP und Peroxynitrit auf die mRNA- Spiegel verschiedener Myelingene in CG-4, OLN-93 und primären glialen Zellen}

Entsprechend den gefundenen Expressionsmustern sind für die jeweils exprimierten Gene Real Time PCRs nach Behandlung der Zellen mit den schädigenden Substanzen durchgeführt worden. Die folgenden Abschnitte beschreiben die Veränderung der mRNA-Expression von PLP, CNP, MBP und MAG in den drei Zellpopulationen jeweils für die verschiedenen Zelltodinduktoren (SNAP, Peroxynitrit, Staurosporin).

\subsubsection{PLP}

Der bereits vorher beobachtete starke Anstieg der Expression der PLP-mRNA in OLN-93Zellen nach Behandlung mit SNAP und Peroxynitrit findet sich im Rahmen dieser Arbeit ebenso nach Inkubation der Zelllinie mit Staurosporin (Abb. 10). Es scheint sich hierbei um ein Phänomen zu handeln, welches unabhängig vom Zelltodinduktor ist.

Im Gegensatz dazu ist der beobachtete Anstieg der PLP-mRNA-Expression weder in CG-4Zellen noch in PMGC-Zellen zu finden (Abb. 10), die mit den gleichen Konzentrationen des Zelltodinduktors für den gleichen Zeitraum inkubiert wurden. Diese beiden Zellpopulationen zeigen entweder keine Veränderung im Expressionsmuster oder sie exprimieren geringfügig weniger PLP-mRNA. In keinem Experiment kommt es dagegen zu einem Anstieg der Expression von dem in OLN-93-Zellen beobachteten Ausmaß. 

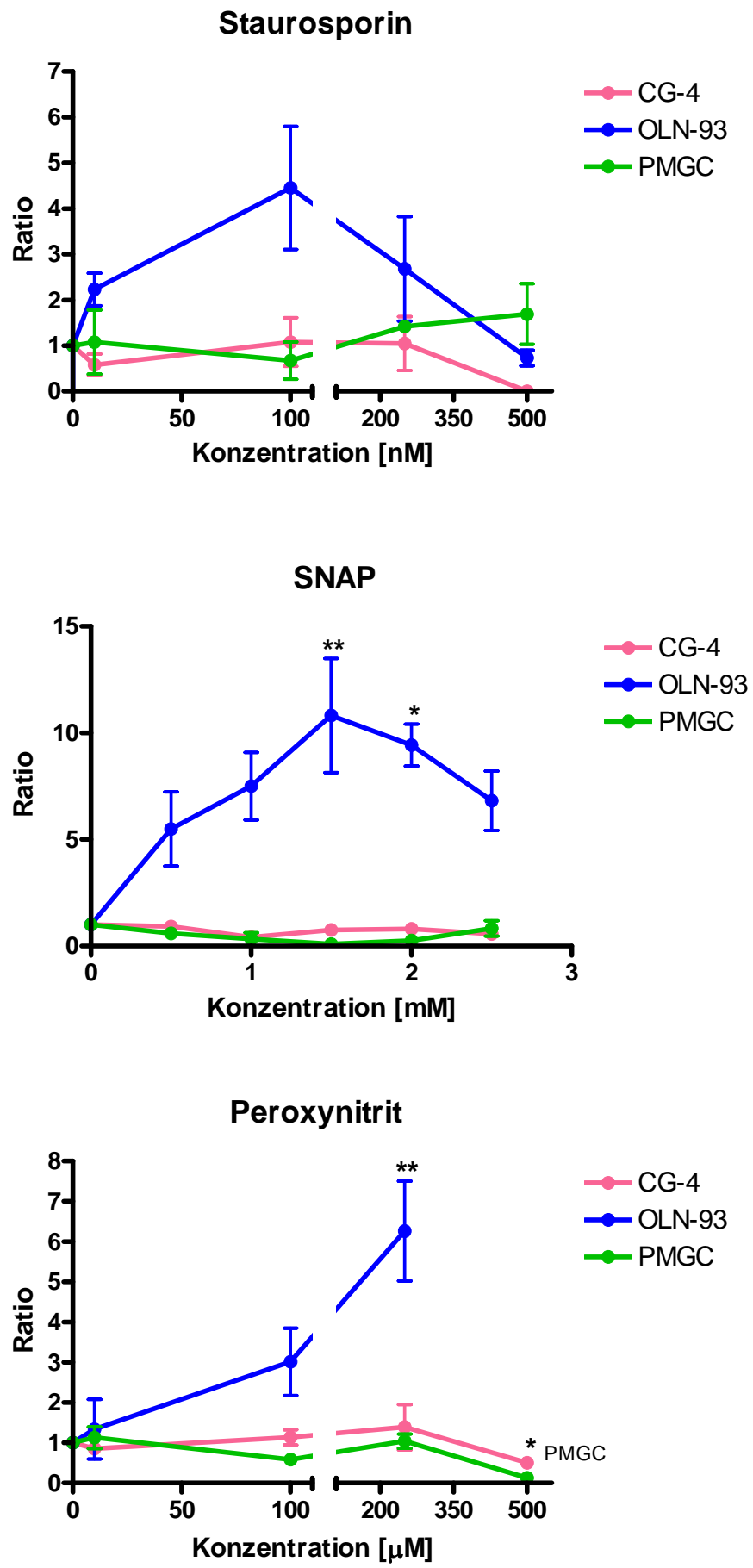

Abb. 10: Die drei Diagramme zeigen die mittels quantitativer Real Time PCR ermittelte Veränderung der mRNA-Expression von PLP jeweils für die drei Zellpopulationen CG-4 (rosa Kurve), OLN-93 (blaue Kurve) und PMGC (grüne Kurve) in Abhängigkeit von der Konzentration des jeweiligen Zelltodinduktors Staurosporin, SNAP und Peroxynitrit.

Deutlich zu sehen ist der Anstieg der PLP-mRNA-Expression in OLN-93-Zellen unabhängig vom Zelltodinduktor. Dagegen zeigt sich eine ähnliche Zunahme weder in CG-4-Zellen noch in PMGC unter den gleichen Bedingungen.

* $\mathrm{P}<0,05 ; * * \mathrm{P}<0,01$ im Vergleich zur unbehandelten Kontrolle. 


\subsubsection{CNP}

Nachdem vorher neben den Veränderungen der PLP-mRNA- Expression zum Vergleich auch die Expression von CNP untersucht wurde, ist der Frage nach der Veränderung der CNPmRNA-Expression auch im Rahmen dieser Arbeit weiterführend nachgegangen worden. Unabhängig vom Zelltodinduktor kommt es hier in CG-4-Zellen und in PMGC-Zellen zu einer gleich bleibenden oder verminderten Expression wie bereits in OLN-93-Zellen beobachtet.
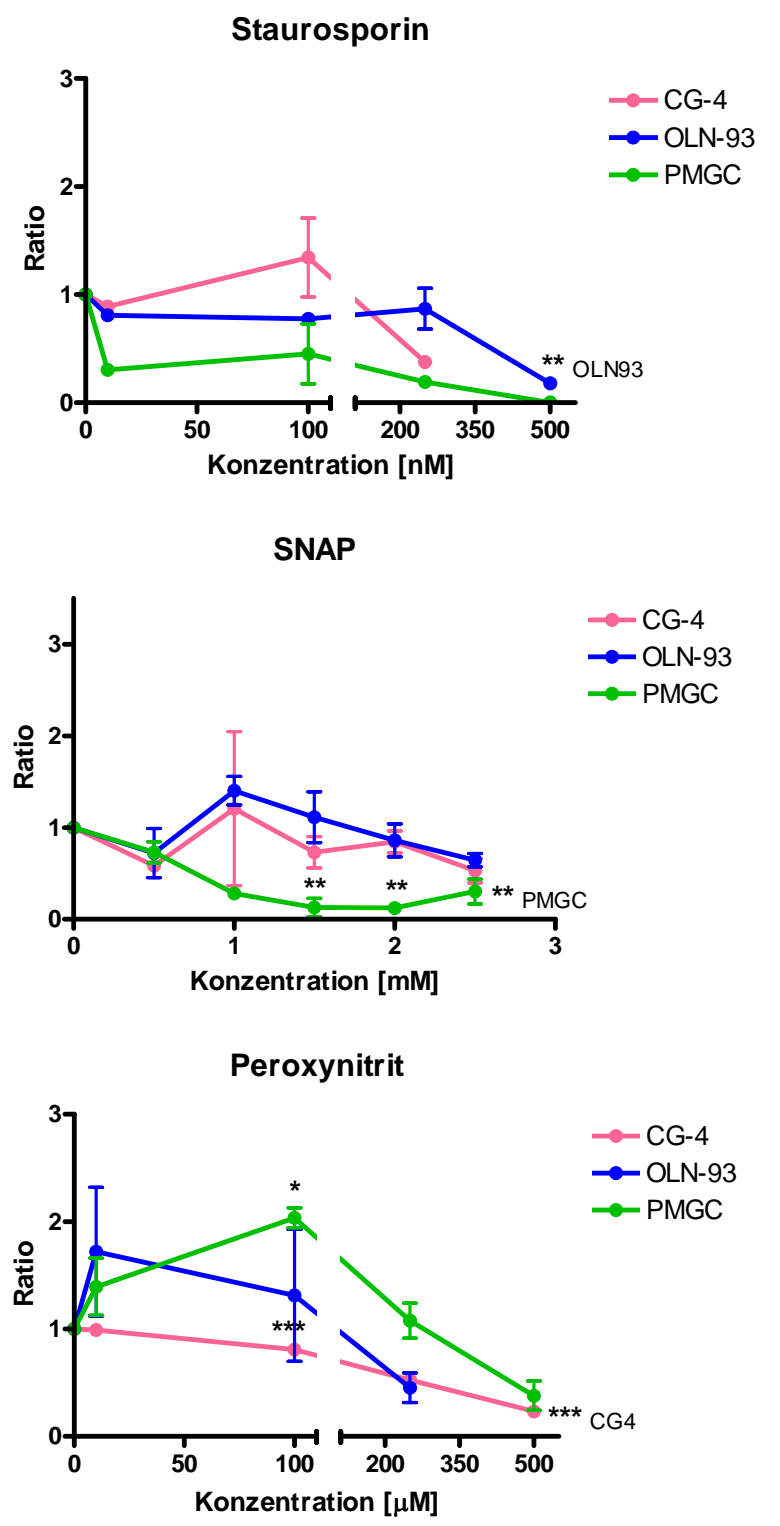

Abb. 11: Gezeigt wird die Veränderung der mRNA-Expression von CNP in den drei Zellpopulationen in Abhängigkeit von den Konzentrationen der Zelltodinduktoren Staurosporin, SNAP und Peroxynitrit. Unabhängig vom Zelltodinduktor zeigt sich in allen Experimenten eine z.T. signifikante Abnahme der mRNAExpression von CNP bei höheren Konzentrationen.

* $\mathrm{P}<0,05 ;{ }^{* *} \mathrm{P}<0,01 ; * * * \mathrm{P}<0,001$ im Vergleich zur unbehandelten Kontrolle. 


\subsubsection{MBP und MAG}

Weiterführend sind neben den Veränderungen der Expression von PLP und CNP auch MBP und MAG untersucht worden. Beide Gene werden nur von CG-4-Zellen und PMGC-Zellen exprimiert (s. Tabelle 1). Die gefundenen Ergebnisse ähneln in beiden Fällen jenen von CNP; auch hier ändert sich die Expression nur geringfügig. In den meisten Experimenten findet sich eine Abnahme der Expression vor allem bei höheren Konzentrationen. Nur nach Behandlung mit $100 \mu \mathrm{M}$ Peroxynitrit exprimieren PMGC-Zellen verstärkt MAG-mRNA (Abb. 13). Dieser beobachtete Anstieg ist allerdings im Vergleich zu den hohen Werten in OLN-93-Zellen für PLP nur gering und nicht signifikant.
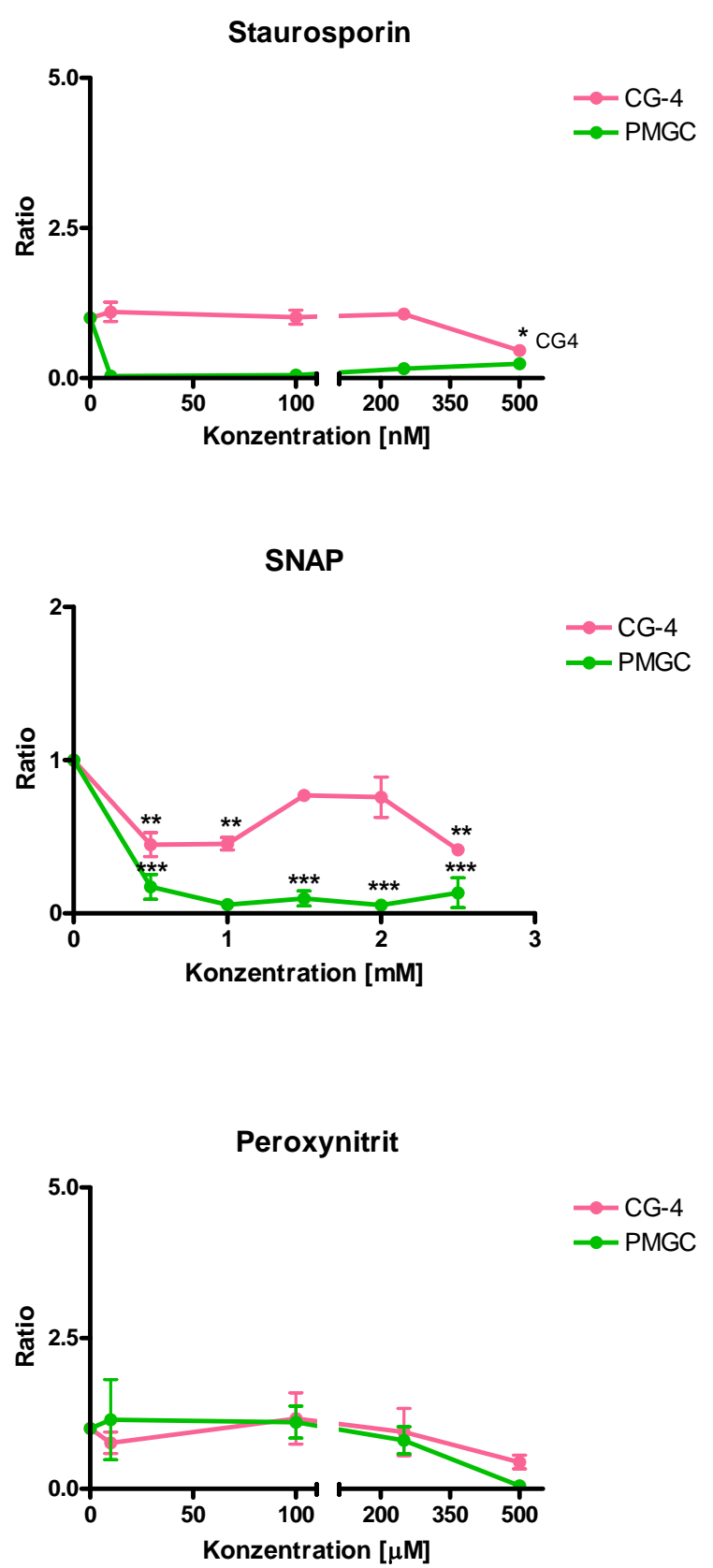

Abb. 12: In den Diagrammen wird die Veränderung der mRNA-Expression von MBP in der Zelllinie CG-4 und den PMGC- Zellen unter Einfluss von den Zelltodinduktoren Staurosporin, SNAP und Peroxynitrit dargestellt. Es zeigt sich, dass die Expression in allen Experimenten abnimmt, z.T. signifikant bereits bei niedrigen Konzentrationen des jeweiligen Zelltodinduktors, z.T. erst bei höheren Konzentrationen. $* \mathrm{P}<0,05 ; * * \mathrm{P}<0,01 ; * * * \mathrm{P}<0,001$
im Vergleich zur unbehandelten
Kontrolle. 

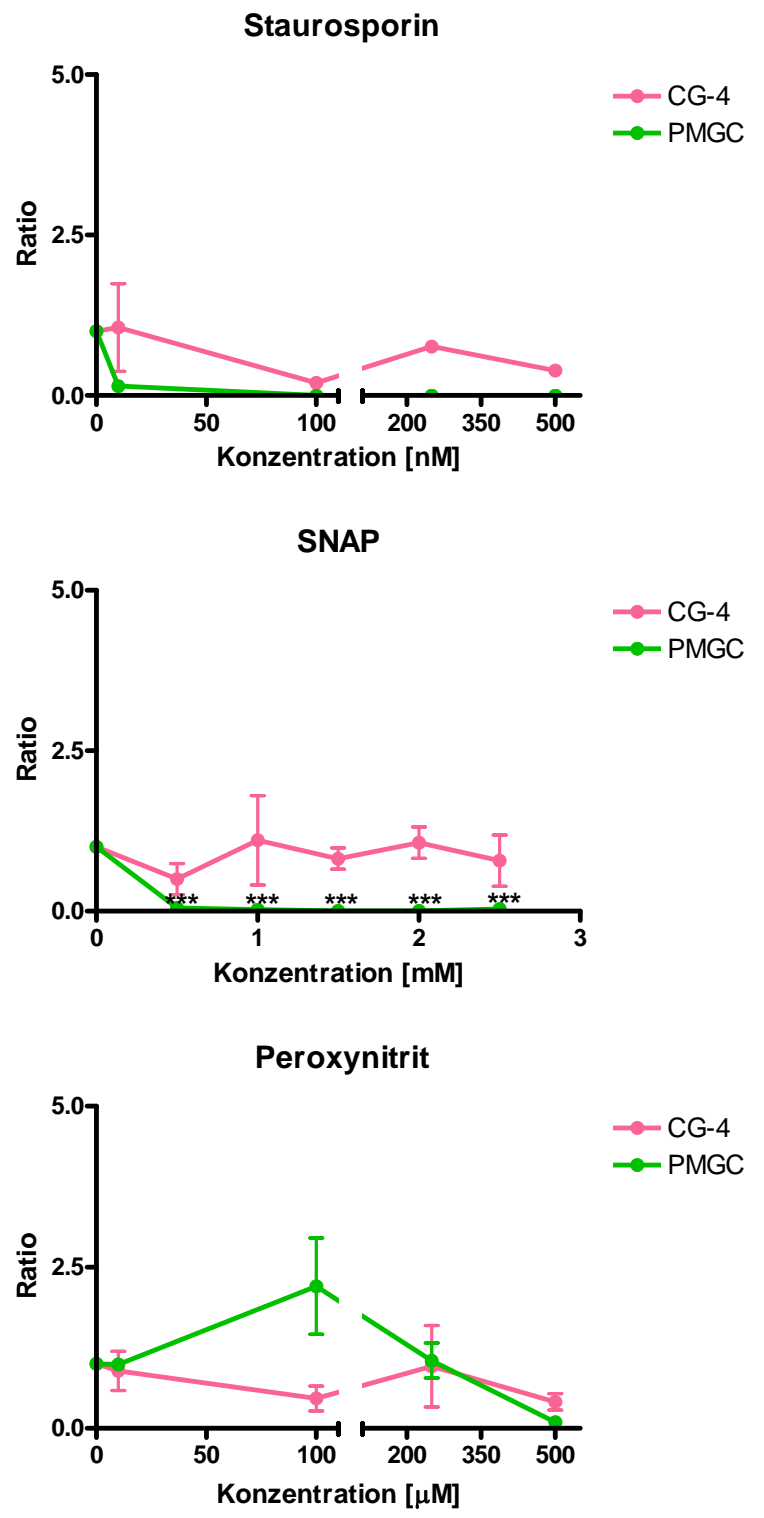

Abb. 13: Gezeigt werden die Veränderungen der mRNA-Expression von MAG in CG-4-Zellen und in PMGCZellen nach Behandlung mit den drei ausgewählten Zelltodinduktoren. Die Expression von MAG-mRNA in CG4-Zellen ändert sich in allen Experimenten kaum oder nimmt geringfügig ab. PMGC-Zellen exprimieren unter Einfluss von bereits niedrigen Konzentrationen Staurosporin und SNAP deutlich weniger MAG-mRNA; nach Behandlung mit Peroxynitrit steigt die Expression bei Inkubation mit Werten um $100 \mu \mathrm{M}$ leicht an. *** $\mathrm{P}<0,001$ im Vergleich zur unbehandelten Kontrolle. 


\section{Diskussion}

Nachdem im Rahmen von vorhergehenden Ergebnissen (Höff 2006) eine veränderte Expression der Myelinproteingene PLP und CNP in der oligodendroglialen Zelllinie OLN-93 nach Inkubation mit Peroxynitrit und dem NO-Donor SNAP beobachtet worden ist, wird im Rahmen dieser Doktorarbeit untersucht, ob es sich dabei um eine spezifische Reaktion von Oligodendrozyten auf schädigende Substanzen handelt.

\subsection{Wirkung der Zelltodinduktoren TRAIL, FasL und Staurosporin auf oligodendrogliale Zellkulturen}

Um zu untersuchen, inwieweit die beiden Mitglieder der TNF-Familie Fas und TRAIL sowie Staurosporin Zelltod in den Kulturen auslösen, wurden nach Beendigung der Inkubationszeit die mitochondriale Respiration und das Ausmaß des Zelltodes untersucht.

\subsubsection{TRAIL}

Es zeigte sich nach Inkubation der oligodendroglialen Zelllinien OLN-93 und CG-4 mit TRAIL bei höheren Konzentrationen im MTT-Test eine Abnahme der mitochondrialen Respiration.

Hierbei scheint es sich aber augenscheinlich nicht um eine erhöhte Zelltodrate zu handeln, da weder der Nukleosomen-ELISA zu einem positiven, auf verstärkten Zelltod im Vergleich zur Kontrolle hinweisenden Ergebnis führte, noch in der TUNEL-Färbung die charakteristisch gefärbten apoptotischen Zellen zu sehen waren. Vor dem Hintergrund dieser Ergebnisse scheint sich die Abnahme der mitochondrialen Respiration trotz des Nachweises des TRAILR2-Rezeptors auf mRNA-Ebene also nicht mit verstärktem Zelltod erklären zu lassen, sondern sie deutet auf einen durch TRAIL ausgelösten Wachstumsstopp hin, so dass sich im Vergleich mit der weiterhin proliferierenden Zellpopulation der Kontrolle relativ gesehen geringere Werte ergeben.

In humanen Oligodendrozyten wird der TRAIL-mediierte Zelltod vor allem durch TRAIL-R1 ausgelöst (Matysiak et al. 2002). Mäuse besitzen im Gegensatz zum Menschen nur einen zelltodinduzierenden TRAIL-Rezeptor, nämlich ein Homolog zum humanen TRAIL-R2. Dieser Rezeptor konnte auch bei Ratten nachgewiesen werden. Auf mRNA-Ebene finden sich bei Mäusen zwei weitere Rezeptoren (DcR1 und 2); diese besitzen allerdings nicht die zytoplasmatische Todesdomäne (Schneider et al. 2003). 
Für unsere Ergebnisse gibt es verschiedene Erklärungsmöglichkeiten: Trotz vorhandener Transkription des TRAIL-R2-Gens könnte die Translation des Proteins unvollständig ablaufen. Auch ein gestörter Transport des Proteins vom Golgi-Apparat zur Zelloberfläche ist nicht auszuschließen. Dann würde es sich bei der TRAIL-induzierten Inhibition der Proliferation um ein unspezifischen, nicht TRAIL-Rezeptor vermittelten Effekt handeln.

Eine zweite, attraktivere Hypothese ist, dass es sich um eine spezifisch durch den TRAILRezeptor vermittelte Inhibition der Proliferation handelt. In der Literatur finden sich zahlreiche Publikationen, die neben der vielbeschriebenen apoptotischen Wirkung von TRAIL auf mögliche nicht-apoptotische Funktionen hinweisen, darunter auch Hemmung der Aktivierung von humanen T-Zellen ohne Auslösung von Apoptose (Lünemann et al. 2002) sowie anti-proliferative Wirkungen durch Zellzyklusarrest in Lymphozyten (Song et al. 2000).

Ähnliches ist möglicherweise auch in den oligodendroglialen Zelllinien denkbar; ein Zellzyklusarrest würde die verminderte Proliferation in Abwesenheit von apoptotischen oder nekrotischen Zellen erklären. Um zu bestimmen, ob es sich bei der durch die TRAIL-Zugabe ausgelösten Inhibition der Proliferation um einen spezifischen, rezeptorvermittelten Effekt handelt, sind weitere Experimente, wie z.B. die Zelltodinduktion bei gleichzeitiger Blockade des TRAIL-Rezeptors mit blockierenden Antikörpern notwendig.

\subsubsection{Fas}

Ebenso führte auch die Inkubation der Zellpopulationen mit FasL nicht zu einer erhöhten Zelltodrate. In diesem Fall fand sich selbst bei sehr hohen Konzentrationen nur bei OLN-93 nach Vorinkubation mit CHX eine signifikante Abnahme der mitochondrialen Respiration, ansonsten entweder keine Veränderung der Rate oder sogar eine Zunahme im Versuch mit CG-4.

Für dieses Phänomen kommen mehrere Erklärungsmöglichkeiten in Betracht:

Nach erfolgreichem Nachweis des Fas-Rezeptors mittels PCR stellt sich als erstes die Frage nach einem möglichen Problem bei der Stimulation von Rattenzelllinien mit humanem FasLiganden. Unterschiede bei Ligand oder Rezeptor zwischen den beiden Spezies sind denkbar, welche entweder zu keiner regelrechten Bindung führen oder nach erfolgter Bindung $\mathrm{zu}$ keiner oder fehlerhafter Aktivierung der nachfolgenden Kaskade führen.

Fas scheint des Weiteren neben einer Rolle beim Zelltod auch eine Vielzahl anderer Funktionen zu besitzen, wie z.B. die Regulation von Regeneration und Proliferation von 
Zellen. Diese nicht-apoptotischen Funktionen sind bei verschiedenen Zellpopulationen beobachtet worden: z.B. exprimieren Hepatozyten den FasR und Bindung des FasL führt im Rahmen vieler Experimente zur Apoptose der Zellen. Allerdings zeigte sich bei Mäusen nach einer partiellen Hepatektomie eine verstärkte Leberregeneration nach Aktivierung von Fas durch eine Injektion eines anti-FasR Antikörpers, also ein proliferationsfördernder Effekt (Desbarats und Newell 2000). Bei den operierten Tieren kam es zu im Gegensatz zu den Kontrolltieren nicht $\mathrm{zu}$ einer Herunterregulation von FLIP, einem Protein, welches die Auslösung von Apoptose durch Bindung an die FADD hemmt.

Weitere nicht-apoptotische Effekte sind in anderen Zellpopulationen, wie z.B. neuronalen Stammzellen (Tamm et al. 2004) und Neuronen (Desbarats et al. 2003, Zuliani et al. 2006) gefunden worden. In verschiedenen Experimenten zeigte sich eine Beteiligung von Fas an vermehrtem Wachstum von Neuriten und verstärkter Regeneration der Neurone nach Schäden bzw. zu verlangsamter Heilung in Abwesenheit von Fas (Desbarats et al. 2003).

Unklar ist weiterhin, wie es genau entweder zu einer pro-apoptotischen oder zu einer nichtapoptotischen Antwort der Zelle nach Aktivierung des FasR kommt und wo die Schnittstellen zwischen den beiden Wegen liegen. Teile der DISC wie FADD, Caspase 8 und c-FLIP könnten hierbei eine Rolle spielen (Park et al. 2005).

Weiterhin könnten posttranslationale Modifikationen für die Auslösung der apoptotischen oder nicht-apoptotischen Kaskade eine Rolle spielen (Chakrabandhu et al. 2006).

Für die Auslösung von Apoptose scheint vor allem die Fähigkeit der Internalisierung des Rezeptors nach Ligandenbindung wichtig zu sein. In Zellen, bei welchen die Internalisierung des Rezeptors nicht möglich ist, werden nach Bindung des FasL proliferationsfördernde Signalwege aktiviert (Lee KH et al. 2006).

Die Frage, wann und unter welchen Umständen der Apoptose-auslösende Signalweg aktiviert wird und wann nicht, lässt sich z.Z. noch nicht vollständig beantworten. Wahrscheinlich werden die verschiedenen Signalkaskaden gleichzeitig aktiviert und es kommt nur unter bestimmten Umständen zur Auslösung von Apoptose. In diesem Zusammenspiel tragen neben Rezeptor-inhibierenden Proteinen und der Hochregulation von protektiven Proteinen auch ungenügende Konzentrationen der Apoptose-auslösenden Proteine zum endgültigen Signal bei (Peter et al. 2007).

Auch hier sind weitere Experimente, z.B. mit FasR blockierenden Antikörpern notwendig, um herauszufinden, ob es sich bei der durch FasL ausgelösten Proliferation in der CG-4Zelllinie um einen spezifischen, Fas-vermittelten Effekt handelt. 


\subsubsection{Staurosporin}

Im Gegensatz zu Fas und TRAIL löste Staurosporin in den behandelten Zellpopulationen erwartungsgemäß schon in geringen Konzentrationen Zelltod aus und es zeigte sich eine zum Teil fast lineare Abnahme der Zellzahl und der mitochondrialen Respiration bei steigenden Konzentrationen. Bereits nach Stimulation mit $5 \mathrm{ng} / \mathrm{ml}$ Staurosporin zeigte die TUNELFärbung viele charakteristisch angefärbte apoptotische Zellen.

\subsection{Wirkung von reaktiven Stickstoffmetaboliten auf oligodendrogliale Zellkulturen}

SNAP ist ein NO-Donor; das freigesetzte Stickoxid bildet zusammen mit Superoxidanionen Peroxynitrit. Durch Nitrierung von Tyrosinresten und S-Nitrosylierung von Enzymen mit Eisenschwefelzentrum unterbricht Peroxynitrit Signaltransduktionswege und hemmt die Enzyme der Atmungskette. Die mögliche Rolle von Peroxynitrit in der Pathogenese von Erkrankungen der weißen Substanz wie neurodegenerativen Erkrankungen, MS und Ischämie ist ungeklärt.

Bei der MS werden histologisch vier verschiedene Subtypen der Läsionen unterschieden. Vor allem im Demyelinisierungsmuster III findet sich massiver Zelltod von Oligodendrozyten und eine differentielle Regulation der Myelinproteingene. Die Ursache des Zelltods ist bislang unklar; es wird die Möglichkeit eines initialen Ereignisses diskutiert (Barnett und Prineas 2004). Bekannt ist, dass Oligodendrozyten anfällig sind für eine Vielzahl von unterschiedlichen Entzündungsmediatoren, Zelltodliganden, Neurotransmittern (z.B. Glutamat) sowie bei oxidativem Stress entstehende Metabolite. So führt zum Beispiel in vitro die Freisetzung von Peroxynitrit durch aktivierte Mikrogliazellen zum Zelltod von Oligodendrozyten (Li J et al. 2005). Dabei exprimieren die Mikrogliazellen die induzierbare NO-Synthase (iNOS). Die Expression dieses Enzyms ist auch in akuten MS-Läsionen in Mikrogliazellen und Astrozyten heraufreguliert (Oleszak et al. 1998).

Neuere Studien aus dem Institut für Neuropathologie der Universität Göttingen in Zusammenarbeit mit der McGill University, Montreal, Kanada zeigen allerdings, dass die Heraufregulation der iNOS in MS-Läsionen nicht mit dem Nachweis oder dem Ausmaß des oligodendroglialen Zelltodes korreliert (Jack et al. 2007). In Einzelfällen ließ sich Nitrotyrosin in untergehenden Oligodendrozyten nachweisen, was darauf hinweisen könnte, dass Peroxynitrit und nicht NO zum oligodendroglialen Zelltod beiträgt (Jack et al. 2007).

Während sich in dieser Studie von Jack et al. humane adulte Oligodendrozyten als relativ resistent gegenüber NO-induziertem Zelltod zeigten, kam es bei den Versuchen mit den 
beiden Zelllinien im Rahmen der vorliegenden Arbeit sowohl nach Inkubation mit Peroxynitrit als auch mit SNAP zu einer signifikant erhöhten Zelltodrate. Dies ist bereits in vitro bei primären glialen Kulturen beobachtet worden (Mitrovic et al. 1994).

Auch in vivo konnte gezeigt werden, dass der Peroxynitrit-Donor SIN-1 nach Injektion zu Schäden an Axonen und Myelin führt (Touil et al. 2001). Die von uns kultivierten primären murinen Gliazellkulturen zeigten dagegen keine Abnahme der mitochondrialen Respiration nach Inkubation mit Peroxynitrit.

Da sich aber in allen anderen Versuchskonstellationen eine signifikante Abnahme zeigte, sind sowohl SNAP bzw. Stickoxid als auch Peroxynitrit geeignet, die von uns als Oligodendrozyten-Modell verwendeten Zellen zu schädigen, um so zu untersuchen, ob diese beiden Substanzen eine differentielle Myelinproteingenregulation hervorrufen wie wir sie in den MS-Läsionen Demyelinisierungsmuster III gesehen haben.

\subsection{Veränderung des Genexpressionsmusters der Myelinproteine unter Zugabe toxischer Faktoren}

Mit den nachfolgenden Experimenten wurde die Veränderung der Myelinproteingene in den drei Zellpopulationen unter dem Einfluss schädigender Substanzen untersucht. Nachdem weder TRAIL noch Fas zu einer Zelltodrate führten, welche über der erwarteten Rate in kultivierten Oligodendrozyten liegt, wurden folglich die beiden bereits vorher verwendeten Zelltod-induzierenden Substanzen Peroxynitrit und SNAP sowie das ebenfalls in den oligodendroglialen Zelllinien Zelltod auslösende Staurosporin benutzt.

Initiale Experimente zeigten eine Heraufregulation von PLP und eine Herunterregulation von CNP auf mRNA-Ebene nach Inkubation der oligodendroglialen Zelllinie OLN-93 mit Stickoxid und Peroxynitrit.

Es zeigte sich, dass dieses Phänomen bei OLN-93 unabhängig vom Zelltodinduktor ist, da auch unter Einfluss des klassischen Apoptoseinduktors Staurosporin OLN-93-Zellen mit einer verstärkten Expression von PLP-mRNA und einer Herunterregulation von CNP-mRNA reagierten.

Für alle anderen Gene fanden wir unabhängig von Zelllinie und Zelltodinduktor eine Herunterregulation. Dass wir in PMGC-Zellen nach Inkubation mit Peroxynitrit zumeist keine signifikante Veränderung der mRNA-Expression fanden, ist nicht überraschend, da sich bereits im MTT-Test keine signifikante Abnahme der mitochondrialen Respiration fand und die Zellen somit nicht geschädigt zu werden scheinen. 
Eine differentielle Regulation von Genen, wie die, die wir in der OLN-93-Zelllinie für PLP und CNP im Rahmen dieser und vorangegangener Arbeiten beobachtet haben, findet man auch bei der sogenannten dying back oligodendrogliopathy. Sie beschreibt eine Degeneration nur der distalen, periaxonalen Fortsätze der Oligodendrozyten bei intaktem Zellkörper und wurde zuerst 1981 von Ludwin und Johnson im Cuprizone-Modell beschrieben. In diesem Modell kommt es zum Verlust von Oligodendrozyten und zu Demyelinisierung. Sehr ähnliche Veränderungen sind auch in aktiven MS-Plaques Demyelinisierungsmuster III zu finden (Lucchinetti et al. 2000). Der molekulare Mechanismus der dying back oligodendrogliopathy ist nicht geklärt. Chronische metabolische Störungen verschiedener Ätiologie im Stoffwechsel der Oligodendrozyten scheinen eine Rolle zu spielen wie z.B. Entzündungen oder Viren. Sie führen dazu, dass die beeinträchtigte Zelle bei eingeschränktem Stoffwechsel nicht in der Lage ist, die distalsten Bereiche (bei den Oligodendrozyten also den direkt dem Axon anliegenden Bereich) zu versorgen und diese somit am anfälligsten für weitere Schäden sind. Die differentielle Regulierung der Myelinproteine ist nicht spezifisch für die MS, sondern ist ein im Rahmen verschiedener Krankheiten beschriebenes Phänomen, wie z.B. bei Ischämie (Aboul-Enein et al. 2003).

Unsere in-vitro-Daten bezüglich der verstärkten PLP-Expression bieten in Zusammenschau mit der Literatur eine interessante Erklärungsmöglichkeit für die Genese einer differentiellen Expression von Myelingenen in MS-Läsionen. Um zu untersuchen, ob sich diese differentielle Myelingenexpression auch in anderen oligodendroglialen Zelllinien bzw. in primären Oligodendrozyten der Maus nach Inkubation mit Zelltodinduktoren nachweisen lassen, wurden entsprechende in-vitro-Experimente durchgeführt.

Dabei stellte sich heraus, dass die differentielle Expression nur in OLN-93-Zellen, jedoch nicht in der Zellinie CG-4 oder primären Oligodendrozyten der Maus zu beobachten ist. Es handelt sich also um ein OLN-93-spezifisches Phänomen. Somit ist es unwahrscheinlich, dass der durch Stickoxid oder Peroxynitrit ausgelöste Zelltod ein Erklärungsmodell für die differentielle Regulation der Myelingene in MS-Läsionen ist. Der Entstehungsmechanismus dieses histologischen Subtyps ist also nach wie vor ungelöst.

Es stellt sich allerdings die Frage, welche Funktion bzw. Konsequenz eine Heraufregulation von PLP, einem Strukturprotein im Myelin, in OLN-93-Zellen hat, welche durch Inkubation mit der jeweiligen zelltodauslösenden Substanz geschädigt worden sind. 
Zelltod von Oligodendrozytenvorläuferzellen findet sich auch noch postpartal in dem Zeitraum, in dem die Zellen ihre späteren Bestimmungsorte finden. Die ursprüngliche Zellzahl ist sehr viel größer als später Zellen benötigt werden, so dass z.B. im Sehnerv bis zu $50 \%$ der Oligodendrozytenvorläuferzellen Zelltod begehen. Ein Grund dafür könnte ein physiologischer Mangel an Wachstumsfaktoren wie PDGF sein (Campagnoni AT und Skoff 2001). Der Zelltod fällt zusammen mit einer verstärkten Expression von PLP und DM20, so dass hier eine Verbindung vermutet werden könnte. Neben diesem physiologischen Zelltod sind Experimente in vitro und in vivo mit Zellen durchgeführt worden, welche zu viel PLP exprimieren.

Die Überexpression von PLP scheint schwerere Auswirkungen zu haben als der Verlust des Proteins: In Versuchstieren mit übermäßiger Expression von PLP kommt es zu Zelltod der Oligodendrozyten. Eine Erklärungsmöglichkeit hierfür wäre, dass die PLP-Expression direkt die Apoptose beeinflusst oder aber, dass die gestörte Myelinformation den Stoffwechsel der Zelle derart schädigt, dass sie Apoptose begeht (Skoff et al. 2004a).

PLP/DM20 überexprimierende Ratten bekommen eine Leukodystrophie, bei der die reifen Oligodendrozyten sterben und die unreifen Oligodendrozyten in einem Stadium verbleiben, welches der Myelinbildung vorausgeht (Bradl et al. 1999). Auch Punktmutationen im Gen können zu toxischen Produkten mit nachfolgendem Zelltod der Oligodendrozyten führen wie z.B. beim M. Pelizaeus-Merzbacher.

Wird dagegen von Oligodendrozyten kein PLP exprimiert, steigt die Zellzahl in Kultur im Vergleich zur Kontrolle um das siebenfache durch verlängerte Überlebenszeit der Zellen bei aber geringerem Differenzierungsgrad (Yang und Skoff 1997). PLP-null-Mäuse zeigen geringe strukturelle Veränderungen im Myelin bei fast normaler Lebenserwartung und Verhalten (Klugmann et al. 1997), wobei allerdings der axonale Transport beeinträchtigt ist und es zu Degeneration der Axone kommt, wie man sie z.B. bei der spastischen Paraplegie findet, für welche die PLP-null-Mäuse ein geeignetes Modell darstellen. Diese Störungen lassen sich evt. mit dem posttranskriptionalen Verlust von SIRT-2, einem Myelinbestandteil bisher unbekannter Funktion, an dessen Transport ins ZNS PLP beteiligt sein könnte, erklären. Der Transport ins ZNS durch PLP könnte von wesentlicher Bedeutung für die unbeeinträchtigte Funktion der Axone sein (Werner et al. 2007).

Auch für nicht-neurale Zellen konnte gezeigt werden, dass eine Parallelität zwischen der Höhe der Expression von PLP und der Apoptoserate besteht, wobei die erhöhte Apoptoserate der PLP überexprimierenden Zellen mit einer starken Ansäuerung der Extrazellulärflüssigkeit erklärbar sein könnte (Skoff et al. 2004 b). 
Zusammenfassend stellt sich also die Frage nach einer potentiellen Rolle für PLP außerhalb der Myelinisierung; vor allem vor dem Hintergrund, dass das Protein embryonal bereits ca. einer Woche vor Beginn der Myelinisierung exprimiert wird.

Die oben genannten Studien scheinen mit unseren Ergebnissen für die Zelllinie OLN-93 zu korrelieren, wobei sich die Frage nach dem Ursache-Wirkungs-Prinzip stellt. Zumeist wird eine erhöhte Apoptoserate nach Erhöhung der Expression von PLP beobachtet. In unseren Experimenten reagierten die Zellen aber mit einer erhöhten Expression von PLP auf schädigende Substanzen, so dass ein direkter Vergleich hier nicht möglich ist.

Zusammenfassend lässt sich sagen, dass sich die erhöhte Expression der PLP-mRNA nur in OLN-93-Zellen findet und weder in CG-4-Zellen noch in primären gemischten Gliazellkulturen unter den gleichen Bedingungen nachweisen läßt. Es scheint sich hierbei also um ein OLN-93-spezifisches Phänomen zu handeln, wobei eine Verbindung zwischen Zelltod und der erhöhten Expression von PLP wie bereits erwähnt in anderen Studien schon untersucht wurde und die endgültige Funktion von PLP in diesem Zusammenhang noch nicht geklärt ist.

In unseren Experimenten zeigen OLN-93-Zellen insgesamt ein von den anderen Zellpopulationen abweichendes Verhalten.

Dies betrifft eine von Oligodendrozyten sowie auch von den primären gemischten Gliazellkulturen und der Zelllinie CG-4 abweichende Expression der Myelinproteingene (Tabelle s. Ergebnisse); d.h. entweder liegt gar keine Expression vor oder eine unter veränderten Bedingungen von den anderen Populationen abweichende Expression. Somit ist eine weitere Schlussfolgerung dieser Arbeit, dass die Zelllinie OLN-93 bei Experimenten, welche die Myelinproteine betreffen, nicht zwangsläufig als Modell für primäre Oligodendrozyten 


\section{Zusammenfassung}

Die Multiple Sklerose (MS) lässt sich histopathologisch in vier verschiedene Subtypen einteilen. Der Subtyp III ist gekennzeichnet durch initialen Verlust der Oligodendrozyten und Zeichen einer dying back Oligodendrogliopathie, bei welcher die Oligodendrozyten ihre distalen, direkt dem Axon anliegenden Anteile nicht mehr versorgen können.

In Läsionen dieses Subtyps fanden wir histologisch mittels immunhistochemischer Färbung eine differentielle Regulation der Myelinproteine mit einem verstärkten Nachweis des Myelinproteins PLP im Vergleich zur umgebenden intakten weißen Substanz, während weitere Myelinproteine wie z.B. CNP in der Läsion nur vermindert nachweisbar waren.

In Zellkulturversuchen mit der Zelllinie OLN-93 nach Zugabe der Zelltod-auslösenden Substanzen SNAP und Peroxynitrit konnten wir mittels Real Time PCR ebenfalls eine Heraufregulation der PLP-mRNA-Expression zeigen.

Mit der vorliegenden Arbeit soll der Frage nachgegangen werden, ob die beobachtete verstärkte Expression der PLP-mRNA in OLN-93-Zellen eine zelltypspezifische Reaktion darstellt oder ob auch andere oligodendrogliale Zellen mit einer solchen Expression auf Zelltod-auslösende Stimuli reagieren und somit eine mögliche Erklärung für die Entstehung des Subtyps III zu finden wäre.

Wir wählten für die Experimente neben OLN-93-Zellen die Zellline CG-4 und primäre gemischte Gliazellkulturen der Maus. In initialen Versuchen zur Wahl der Zelltodauslösenden Substanzen arbeiteten wir mit TRAIL und FasL, welche aber in den von uns gewählten Zellreihen nicht zu einer gesteigerten Zelltodrate führten.

Mittels MTT-Test, Nukleosomen-ELISA und TUNEL-Färbung konnten wir dagegen Zelltod in den mit SNAP, Peroxynitrit und Staurosporin behandelten Kulturen nachweisen. Aus den mit verschiedenen Konzentrationen behandelten Zellen extrahierten wir die RNA und bestimmten mittels Real Time PCR die Expressionsrate der ausgewählten Myelinproteine PLP, CNP, MBP, MAG und MOG.

Es zeigte sich, dass in OLN-93-Zellen die verstärkte PLP-mRNA-Expression bei allen gewählten Zelltod-auslösenden Substanzen auftrat. Da sich ein ähnliches Phänomen weder bei CG-4-Zellen noch bei primären gemischten Gliazellkulturen zeigte, scheint es sich hier um ein OLN-93-spezifisches Reaktionsmuster zu handeln.

Alle anderen untersuchten Myelinproteine zeigten entweder keine Veränderung oder eine Abnahme der Expression. 
Zusammenfassend konnten wir also zeigen, dass OLN-93-Zellen mit einer verstärkten PLPExpression auf schädigende Substanzen reagieren. Eine ähnliche Reaktion fand sich bei weiteren glialen Zellreihen nicht. Somit erscheint es unwahrscheinlich, dass der in MSLäsionen Subtyp III immunhistochemisch nachgewiesene hohe PLP-Anteil auf ein spezifisches oligodendrogliales Reaktionsmuster, ausgelöst durch oxidativen Stress oder zelltodauslösende Stimuli, zurückzuführen ist. Die genaue Entstehungsweise dieses Subtyps ist also weiterhin nicht geklärt. Es stellt sich zudem die Frage, ob die Zelllinie OLN-93 für Experimente, die die Myelinproteine betreffen, geeignet ist, da sie in unseren Experimenten deutlich abweichende Reaktionen im Vergleich zu Primärkulturen zeigt. 


\section{Literaturverzeichnis}

Aboul-Enein F, Rauschka H, Kornek B, Stadelmann C, Stefferl A, Brück W, Lucchinetti C, Schmidbauer M, Jellinger K, Lassmann H (2003): Preferential loss of myelin-associated glycoprotein reflects hypoxia-like white matter damage in stroke and inflammatory brain diseases. J Neuropathol Exp Neurol 61(1), 25-33

Bagasra O, Michaels FH, Zheng YM, Bobroski LE, Spitsin SV, Fu ZF, Tawadros R, Koprowski H (1995): Activation of the inducible form of nitric oxide synthase in the brains of patients with multiple sclerosis. Proc Natl Acad Sci USA 92, 12041-12045

Barnett MH, Prineas JW (2004): Relapsing and remitting multiple sclerosis: Pathology of the newly forming lesion. Ann Neurol 55, 458-468

Bartsch S, Montag D, Schachner M, Bartsch U (1997): Increased number of unmyelinated axons in optic nerves of adult mice deficient in the myelin-associated glycoprotein (MAG). Brain Res $\underline{762}, 231-234$

Bartsch U, Kirchhoff F, Schachner M (1989): Immunohistological localization of the adhesion molecules L1, N-CAM and MAG in the developing and adult optic nerve of mice. $\mathbf{J}$ Comp Neurol 284, 451-462

Bifulco M, Laezza C, Stingo S, Wolff J (2002): 2',3'-cyclic nucleotide 3'-phosphodiesterase: A membrane-bound, microtubule-associated protein and membrane anchor for tubulin. Proc Natl Acad Sci 99, 1807-1812

Bradl M, Bauer J, Inomata T, Zielasek J, Nave K-A, Toyka K, Lassmann H, Wekerle H (1999): Transgenic Lewis rats overexpressing the proteolipid protein gene: Myelin degeneration and its effect on $\mathrm{T}$ cell-mediated experimental autoimmune encephalomyelitis. Acta Neuropathol 97, 595-606

Brundin L, Morcos E, Olsson T, Wiklund N, Andersson M (1999): Increased intrathekal nitric oxide formation in multiple sclerosis; cerebrospinal fluid as activity marker. Eur J Neurol $\underline{5}$, $585-590$

Brunner C, Lassmann H, Waehneldt TV, Matthieu JM, Linington C (1989): Differential ultrastructural localization of myelin basic protein, myelin/oligodendroglial glycoprotein, and 2 ',3'-cyclic nucleotide $3^{\prime}$-phosphodiesterase in the CNS of adult rats. J Neurochem $\underline{52}$, 296304

Campagnoni AT, Skoff RP (2001): The pathobiology of myelin mutants reveal novel biological functions of the MBP und PLP genes. Brain Pathol 11(1), 74-91

Campagnoni AT, Campagnoni CW: Myelin Basic Protein Gene; in: Myelin Biology and Disorders, Band 1; hrsg. v. Robert Lazzarini; Elsevier, San Diego, Californien, USA 2004, $387-400$

Cascino I, Fiucci G, Papoff G, Ruberti G (1995): Three functional soluble forms of the human apoptosis- inducing Fas molecule are produced by alternative splicing. J Immunol 154, 27062713 
Chakrabandhu K, Herincs Z, Huault S, Dost B, Peng L, Conchonaud F, Marguet D, He HT, Hueber AO (2006): Palmitolyation is required for efficient Fas cell death signaling. EMBO J $\underline{26}, 209-220$

Choi C, Benviste EN (2004): Fas ligand/Fas system in the brain: regulator of immune and apoptotic responses. Brain Res Brain Res Rev 44, 65-81

Connolly K, Cho YH, Duan R, Fikes J, Gregorio T, La-Fleur DW, Okoye Z, Salcedo TW, Santiago G, Ullrich S, Wei P, Windle K, Wong E, Yao XT, Zhang YQ, Zheng G, Moore PA (2001): In vivo inhibition of Fas ligand- mediated killing by TR6, a Fas ligand decoy receptor. J Pharmacol Exp Ther 298, 25-33

Cross AH, Keeling RM, Goorha S, San M, Rodi C, Wyatt PS, Manning PT, Misko TP (1996): Inducible nitric oxide synthase gene expression and enzyme activity correlate with disease activity in murine experimental allergic encephalomyelitis. J Neuroimmunol $\underline{71}, 145-153$

Cross AH, Manning PT, Keeling RM, Schmidt RE, Misko TP (1998): Peroxynitrite formation within the central nervous system in active multiple sclerosis. J Neuroimmunol $\underline{88(1)}, 45-56$

De Angelis DA, Braun PE (1996): 2',3'-Cyclic nucleotide 3'-phosphodiesterase binds to actin-based cytoskeletal elements in an isoprenylation-independent manner. J Neurochem. $\underline{67(3)}, 943-51$

Delarasse C, Daubas P, Mars L, Vizler C, Litzenburger T, Iglesias A, Bauer J, Della Gaspera B, Schubart A, Decker L, Roussel G, Dierich A, Amor S, Dautigny A, Liblau R, Pham-Dinh D (2003): Myelin/oligodendrocyte glycoprotein (MOG)-deficient mice reveal lack of tolerance to MOG in wild-type mice. J Clin Invest 112, 544-553

Desbarats J, Newell MK (2000): Fas engagement accelerates liver regeneration after partial hepatectomy. Nat Med $\underline{6}, 920-923$

Desbarats J, Birge RB, Mimouni-Rongy M, Weinstein DE, Palerme JS, Newell MK (2003): Fas engagement induces neurite growth through ERK activation and p35 upregulation. Nat Cell Biol $\underline{5}, 118-125$

D'Souza SD, Bonetti B, Balasingam V, Cashman NR, Barker PA, Troutt AB, Raine CS, Antel JP (1996): Multiple sclerosis: Fas signaling in oligodendrocyte cell death. J Exp Med $\underline{184}, 2361-2370$

Filipovic R, Rakic S, Zecevic N (2002): Expression of Golli proteins in adult human brain and in multiple sclerosis lesions. J Neuroimmunol. 127, 1-12

Hilliard B, Wilmen A, Seidel C, Liu TT, Göke R, Chen Y (2001): Roles of TNF-Related Apoptosis-Inducing Ligand in Experimental Autoimmune Encephalomyelitis. J Immunol 166, 1314-1319

Höff C, Göttingen: Mündliche Mitteilung 2006. 
Hövelmeyer N, Hao Z, Kranidioti K, Kassiotis G, Buch T, Frommer F, von Hoch L, Kramer D, Minichiello L, Kollias G, Lassmann H, Waisman A (2005): Apoptosis of oligodendrocytes via Fas and TNF-R1 is a key event in the induction of experimental autoimmune encephalomyelitis. J Immunol $\underline{175}, 5875-5884$

Hughes SM, Lillien LE, Raff MC, Rohrer H, Sendtner M (1988): Ciliary neurotrophic factor induces type-2 astrocyte differentiation in culture. Nature $\underline{335}, 70-73$

Jack C, Antel J, Brück W, Kuhlmann T (2007): Contrasting potential of nitric oxide and peroxynitrite to mediate oligodendrocyte injury in multiple sclerosis. Glia 55, 926-934

Jenkins M, Keir M, McCune JM (2000): A membrane-bound Fas decoy receptor expressed by human thymocytes. J Biol Chem $\underline{275}, 7988-7993$

Jurewicz A, Matysiak M, Andrzejak S, Selmaj K (2006): TRAIL-induced death of human adult oligodendrocytes is mediated by JNK pathway. Glia $\underline{53}, 158-166$

Kimberley FC, Screaton GR (2004): Following a TRAIL: Update on a ligand and its five receptors. Cell Res 14(5), 359-372

Kimura M, Sato M, Akatsuka A, Saito S, Ando K, Yokoyama M, Katsuki M (1998): Overexpression of a minor component of myelin basic protein isoform $(17.2 \mathrm{kDa})$ can restore myelinogenesis in transgenic shiverer mice. Brain Res $\underline{785}$, 245-252

Kischkel FC, Lawrence DA, Chuntharapai A et al (2000): Apo2L/TRAIL dependent recruitment of endogenous FADD and caspase- 8 to death receptors 4 and 5. Immunity $\underline{12}$, 611-620

Klugmann M, Schwab MH, Puhlhofer A, Schneider A, Zimmermann F, Griffiths IR, Nave KA (1997): Assembly of CNS myelin in the absence of proteolipid protein. Neuron 18(1), 5970

Knowles RG, Moncada S (1994): Nitric oxide synthases in mammals. Biochem J 298, 249258

Lassmann H, Bartsch U, Montag D, Schachner M (1997): Dying- back oligodendrogliopathy: A late sequel of myelin-associated glycoprotein deficiency. Glia $\underline{19}, 104-110$

Lee J, O’Neill RC, Park MW, Gravel M, Braun PE (2006): Mitochondrial localization of CNP2 is regulated by phosphorylation of the N-terminal targeting signal by PKC: implications of a mitochondrial function for CNP2 in glial and non-glial cells. Mol Cell Neurosci 31(3), 446-62

Lee KH, Feig C, Tchikov V, Schickel R, Hallas C, Schutze S, Peter ME, Chan AC (2006): The role of receptor internalization in CD95 signaling. EMBO J 25, 1009-1023

Li H, Zhu H, Xu CJ, Yuan J (1998): Cleavage of BID by caspase 8 mediates the mitochondrial damage in the Fas pathway of apoptosis. Cell $\underline{94}, 491-501$ 
Li J, Baud O, Vartanian T, Volpe JJ, Rosenberg PA (2005): Peroxynitrite generated by inducible nitric oxide synthase and NADPH oxidase mediates microglial toxicity to oligodendrocytes. Proc Natl Acad Sci U S A, 102(28), 9936-9941.

Li W, Maeda Y, Ming X, Cook S, Chapin J, Husar W, Dowling P (2002): Apoptotic death following Fas activation in human oligodendrocyte hybrid cultures. J Neurosci Res $\underline{69}, 189$ 196

Liu JS, Zhao ML, Brosnan CF, Lee SC (2001): Expression of inducible nitric oxide synthase and nitrotyrosine in multiple sclerosis lesions. Am J Pathol 158, 2057-2066

Lizasoain I, Moro MA, Knowles RG, Darley-Usmar V, Moncada S (1996): Nitric oxide and peroxynitrite exert distinct effects on mitochondrial respiration which are differentially blocked by glutathione or glucose. Biochem J $\underline{314}$, 877-880

Louis JC, Magal E, Muir D, Manthorpe M, Varon S (1992): CG-4, a new bipotential glia cell line from rat brain, is capable of differentiating in vitro into either mature oligodendrocytes or type-2 astrocytes. J Neurosci Res $\underline{31}$, 193-204

Lublin FD, Reingold SC (1996): Defining the clinical course of multiple sclerosis: results of an international survey. National Multiple Sclerosis Society (USA) Advisory Committee on Clinical Trials of New Agents in Multiple Sclerosis. Neurology 46(4),907-11

Lucchinetti C, Brück W, Parisi J, Scheithauer B, Rodriguez M, Lassmann H (2000): Heterogeneity of multiple sclerosis lesions: implications for the pathogenesis of demyelination. Ann Neurol 47, 707-717

Ludwin SK, Johnson ES (1981): Evidence of a "dying-back"gliapathy in demyelinating disease. Ann Neurol $\underline{9}, 301-305$

Lünemann JD, Waiczies S, Ehrlich S, Wendling U, Seeger B, Kamradt T, Zipp F (2002): Death ligand TRAIL induces no apoptosis but inhibits activation of human (auto)antigenspecific T cells. J Immunol $\underline{168}, 4881-4888$

Masure S, Haefner B, Wesselink JJ, Hoefnagel E, Mortier E, Verhasselt P, Tuytelaars A, Gordon R, Richardson A (1999): Molecular cloning, expression and characterization of the human serin/threonin kinase Akt-3. Eur J Biochem 265(1), 353-60

Matysiak M, Jurewicz A, Jaskolski D, Selmaj K (2002): TRAIL induces death of human oligodendrocytes isolated from adult brain. Brain $\underline{125}$, 2469-2480

Mitrovic B, Ignarro LJ, Montestruque S, Smoll A, Merrill JE (1994): Nitric oxide as a potential pathological mechanism in demyelination: its differential effects on primary glial cells in vitro. Neuroscience $\underline{61(3)}, 575-585$

Montag D, Giese KP, Bartsch U, Martini R, Lang Y, Bluthmann H, Karthigasan J, Kirschner DA, Wintergerst ES, Nave KA, Zielasek J, Toyka KV, Lipp H, Schachner M (1994): Mice deficient for the myelin-associated glycoprotein show subtle abnormalities in myelin. Neuron $\underline{13}, 229-246$ 
Nakano H, Omura S (2009): Chemical biology of natural indolocarbazole products: 30 years since the discovery of staurosporine. J Antibiot (Tokyo) 62(1), 17-26

Oleszak EL, Zaczynska E, Bhattacharjee C, Butunoi C, Ledigo A, Katsetos C (1998): Inducible nitric oxide synthase and nitrotyrosine are found in monocytes/macrophages and/or astrocytes in acute, but not in chronic multiple sclerosis. Clin Diagn Lab Immunol $\underline{5}, 438-445$

Park SM, Schickel R, Peter ME (2005): Nonapoptotic functions of FADD-binding death receptors and their signaling molecules. Curr Opin Cell Biol 17, 610-616

Peet GW, Li J (1999): IkappaB kinases alpha und beta show a random sequential kinetic mechanism and are inhibited by staurosporine and quercetin. J Biol Chem 274(46), 32655-61

Peter ME, Budd RC, Desbarats J, Hedrick SM, Hueber AO, Newell MK, Owen LB, Pope RM, Tschopp J, Wajant H, Wallach D, Wiltrout RH, Zörnig M, Lynch DH (2007): The CD95 Receptor: Apoptosis Revisited. Cell 129, 447-450

Prat A, Antel J (2005): Pathogenesis of multiple sclerosis. Curr Opin Neurol 18(3), 225-30

Rejdak K, Eikelenboom MJ, Petzold A, Thompson EJ, Stelmasiak Z, Lazeron RH, Barkhof F, Polman CH, Uitdehaag BM, Giovannoni G (2004): CSF nitric oxide metabolites are associated with activity and progression of multiple sclerosis. Neurology $\underline{63}, 1439-1445$

Richter-Landsberg C, Heinrich M (1996): OLN-93: A new permanent oligodendroglial cell line derived from primary rat brain glial cultures. J Neurosci Res $\underline{45}, 161-173$

Scaffidi C, Schmitz I, Zha J, Korsmeyer SJ, Krammer PH, Peter ME (1999): Differential modulation of apoptosis sensitivity in CD95 type I and type II cells. J Biol Chem $\underline{274(32)}, 22532-8$

Schindler P, Luu B, Sorokine O, Trifilieff E, Van Dorsselaer A (1990): Developmental Study of proteolipids in bovine brain: a novel proteolipid and DM-20 appear before proteolipid protein (PLP) during myelination. J Neurochem 55(6), 2079-85

Schneider P, Olson D, Tardivel A, Browning B, Lugovskoy A, Gong D, Dobles M, Hertig S, Hofmann K, Van Vlijmen H, Hsu YM, Burkly LC, Tschopp J, Zheng TS (2003):

Identification of a new murine tumor necrosis factor receptor locus that contains two novel murine receptors for tumor necrosis factor-related apoptosis-inducing ligand (TRAIL). J Biol Chem 278(7), 5444-54

Skoff RP, Saluja I, Bessert D, Yang X (2004 a): Analyses of proteolipid protein mutants show levels of proteolipid protein regulate oligodendrocyte number and cell death in vitro and in vivo. Neurochem Res 29(11), 2095-2103

Skoff RP, Bessert DA, Cerghet M, Franklin MJ, Rout UK, Nave K-A, Carlock L, Ghandour MS, Armant DR (2004 b): The myelin proteolipid protein modulates apoptosis in neural and non-neural tissues. Cell Death Differ $\underline{11}$, 1247-1257

Song K, Chen Y, Goke R, Wilmen A, Seidel C, Goke A, Hilliard B (2000): Tumor necrosis factor-related apoptosis-inducing ligand (TRAIL) is an inhibitor of autoimmune inflammation and cell cycle progression. J Exp Med 191, 1095-1103 
Stepczynska A, Lauber K, Engels IH, Janssen O, Kabelitz D, Wesselborg S, Schulze-Osthoff K (2001): Staurosporine and conventional anticancer drugs induce overlapping, yet distinct pathways of apoptosis and caspase activation. Oncogene 20(10), 1193-202

Storch MK, Stefferl A, Brehm U, Weissert R, Wallstrom E, Kerschensteiner M, Olsson T, Linington C, Lassmann H (1998): Autoimmunity to myelin oligodendrocyte glycoprotein in rats mimics the spectrum of multiple sclerosis pathology. Brain Pathol $\underline{8}, 681-694$

Tamm C, Robertson JD, Sleeper E, Enokson M, Emgard M, Orrenius S, Ceccatelli S (2004): Differential regulation of the mitochondrial and death receptor pathways in neural stem cells. Eur J Neurosci 19, 2613-2621

Touil T, Deloire-Grassin MSA, Vitek MP, Petry KG, Brochet B (2001): In vivo damage of CNS myelin and axons induced by peroxynitrite. Neuroreport $\underline{12}, 3637-3644$

Van der Veen RC, Hinton DR, Incardonna F, Hofman FM (1997): Extensive peroxynitrite activity during progressive stages of central nervous system inflammation. J Neuroimmunol $\underline{77(1)}, 1-7$

Walsh K, Sata M (1999): Negative regulation of inflammation by Fas ligand expression on the vascular endothelium. Trends Cardiovasc Med $\underline{9}, 34-41$

Weiss MD, Hammer J, Quarles RH (2000): Oligodendrocytes in aging mice lacking myelinassociated glycoprotein are dystrophic but not apoptotic. J Neurosci Res $\underline{62}, 772-780$

Werner HB, Kuhlmann K, Shen S, Uecker M, Schardt A, Dimova K, Orfaniotou F, Dhaunchak A, Brinkmann BG, Möbius W, Guarente L, Casaccia-Bonnefil P, Jahn O, Nave KA (2007): Proteolipid protein is required for transport of sirtuin 2 into CNS myelin. J Neurosci 27(29), 7717-30

Yang X, Skoff RP (1997): Proteolipid protein regulates the survival and differentiation of oligodendrocytes. J Neurosci 17, 2056-2070

Zhu B, Luo L, Chen Y, Paty DW, Cynader MS (2002): Intrathecal Fas ligand infusion strengthens immunoprivilege of central nervous system and suppresses experimental autoimmune encephalomyelitis. J Immunol 169(3), 1561-9

Zuliani C, Kleber S, Klussmann S, Wenger T, Kenzelmann M, Schreglmann N, Martinez A, del Rio JA, Soriano E, Vodrazka P et al (2006): Control of neuronal branching by the death receptor CD95 (Fas/Apo-1). Cell Death Differ 13, 31-40 


\section{Danksagung}

\section{Ich danke...}

* Herrn Prof. Dr. med. W. Brück für die Vergabe des Themas und die Möglichkeit, in seiner Abteilung arbeiten zu dürfen.

* Frau Prof. Dr. med. Tanja Kuhlmann für ihre hervorragende Betreuung inklusive schneller Korrekturen.

* Christiane Höff, deren Ergebnisse den Grundstein meiner Arbeit bilden.

* Jasmin Held, für alles, was sie mir beigebracht hat.

* Amke Hesse für die schöne und lehrreiche gemeinsame Zeit in der Neuropathologie.

* allen anderen Doktoranden und Mitarbeitern der Abteilung, die mich so freundlich unterstützt haben. 